DOE/EIA-0591

Distribution Category UC-950

\title{
The Value of Underground Storage in Today's Natural Gas Industry
}

March 1995

\author{
Energy Information Administration \\ Office of Oil and Gas \\ U.S. Department of Energy \\ Washington, DC 20585
}

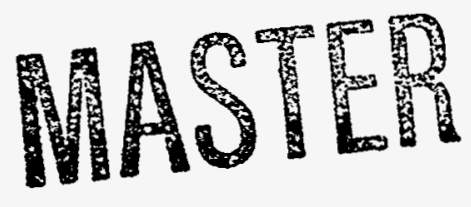

DISTRIBUTION OF THIS DOCUMENT IS UNLIMITED

This report was prepared by the Energy Information Administration, the independent statistical and analytical agency within the Department of Energy. The information contained herein should not be construed as advocating or reflecting any policy position of the Department of Energy or any other organization. 


\section{DISCLAIMER}

This report was prepared as an account of work sponsored by an agency of the United States Government. Neither the United States Government nor any agency thereof, nor any of their employees, make any warranty, express or implied, or assumes any legal liability or responsibility for the accuracy, completeness, or usefulness of any information, apparatus, product, or process disclosed, or represents that its use would not infringe privately owned rights. Reference herein to any specific commercial product, process, or service by trade name, trademark, manufacturer, or otherwise does not necessarily constitute or imply its endorsement, recommendation, or favoring by the United States Government or any agency thereof. The views and opinions of authors expressed herein do not necessarily state or reflect those of the United States Government or any agency thereof. 


\section{DISCLAIMER}

Portions of this document may be illegible in electronic image products. Images are produced from the best available original document. 


\section{Preface}

The Value of Underground Storage in Today's Natural Gas Industry has been prepared by the Energy Information Administration (EIA) to provide the latest information on storage activities. The contribution of storage to the overall efficiency of the production and transmission segments of the industry is well known. However, traditional ideas about storage management have changed and new uses for storage have developed, as the result of both market pressures and regulatory changes. This report analyzes these important changes in the industry.

The report consists of three chapters and four appendices. Chapter 1 provides basic information on the role of storage in today's marketplace where natural gas is treated as a commodity. Chapter 2 provides statistical analyses of the relationship between storage and spot prices on both a monthly and daily basis. For the daily analysis, temperature data were used as a proxy for storage withdrawals, providing a new means of examining the short-term relationship between storage and spot prices. Chapter 3 analyzes recent trends in storage management and use, as well as plans for additions to storage capacity. It also reviews the status of the new uses of storage resulting from Order 636, that is, marketbased rates and capacity release.

Appendix A serves as a stand-alone primer on storage operations, and Appendix B provides further data on plans for the expansion of storage capacity. Appendix $C$ explains recent revisions made to working gas and base gas capacity on the part of several storage operators in 1991 through 1993. The revisions were significant, and this appendix provides a consistent historical data series that reflects these changes. Finally, Appendix D presents more information on the regression analysis presented in Chapter 2.

Data and sources used in the report include: national-level storage data from EIA's Natural Gas Monthly; field-level storage data from Form EIA-191, "Underground Gas Storage Report"; capacities of proposed storage projects from the Office of Oil and Gas' "Proposed Natural Gas Storage Projects" data base; information on market-based rates and capacity release from filings at the Federal Energy Regulatory Commission; Henry Hub spot prices from Pasha Publications Inc., Gas Daily, and McGraw Hill, Inside F.E.R.C's Gas Market Report; estimated weekly storage data from the American Gas Association's American Gas Storage Survey; and temperature data from the National Oceanic and Atmospheric Administration, National Climatic Data Center. Unless otherwise stated, historical data through 1992 on natural gas production, consumption, and price come from EIA, Natural Gas Annual 1992, Vols. 1 and 2, DOE/EIA0131(92)/1 and 2 (Washington, DC, November 1993). Similar annual data for 1993 and monthly data for 1993 and 1994 come from various issues of EIA's Natural Gas Monthly $(N G M), \mathrm{DOE} / \mathrm{EIA}-0130$ (Washington, DC). Data from the $N G M$ are preliminary estimates.

The Value of Underground Storage in Today's Natural Gas Industry was prepared by the Energy Information Administration, Office of Oil and Gas, under the direction of Diane W. Lique (202/586-6401). General Information concerning this report may be obtained from Joan E. Heinkel (202/586-4680), Chief of the Natural Gas Analysis Branch. Detailed questions may be addressed to the following analysts:

- Chapter 1. "Importance of Storage in the Gas Industry," John H. Herbert (202/586-4360).

- Chapter 2. "Relationship Between Natural Gas Prices and Storage Activity," Mary E. Carlson (202/5864749) and John H. Herbert (202/586-4360).

- Chapter 3. "Changes in Storage Operations," Philip Shambaugh (202/586-4833), James M. Thompson (202/586-6201) and James Tobin (202/586-4835).

- Appendix A, "Underground Natural Gas Storage Operations," James Tobin (202/586-4835).

- Appendix B, "Proposed Additions to Underground Natural Gas Storage," James M. Thompson (202/586-6201).

- Appendix C, "Revisions to Working Gas Storage Data," Philip Shambaugh (202/586-4833).

- Appendix D, "Regression Analysis Results," John H. Herbert (202/586-4360).

Overall coordination of the report was provided by John $\mathrm{H}$. Herbert. Significant analytical contributions were made to Chapters 1 and 3 by Lillian (Willie) Young.

Editorial support was provided by Doris Wells, Ann C. Whitfield, and Willie Young. Desktop publishing support was provided by Margareta Bennett. 



\section{Contents}

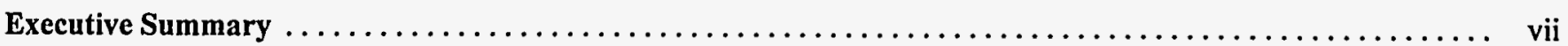

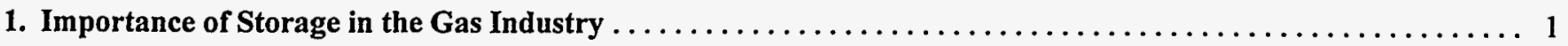

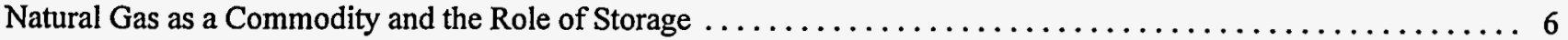

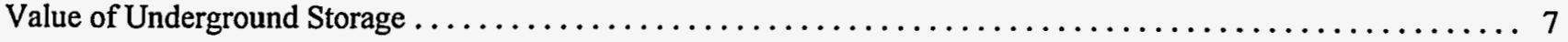

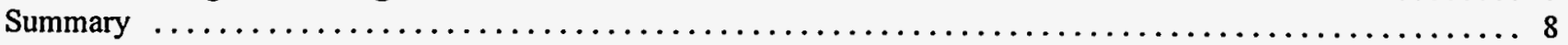

2. Relationship Between Natural Gas Prices and Storage Activity $\ldots \ldots \ldots \ldots \ldots \ldots \ldots \ldots \ldots \ldots \ldots \ldots \ldots$

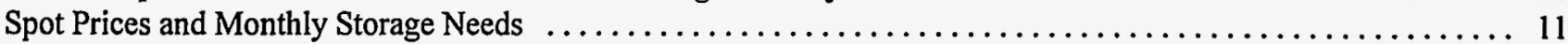

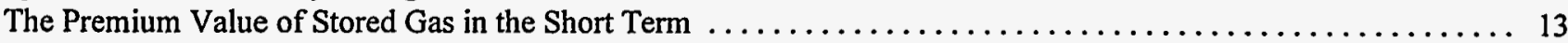

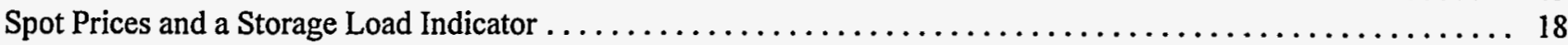

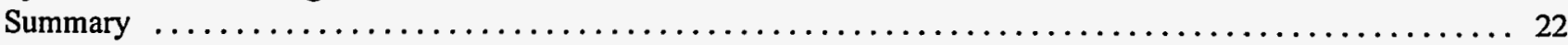

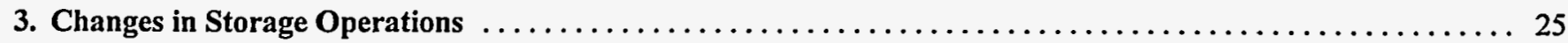

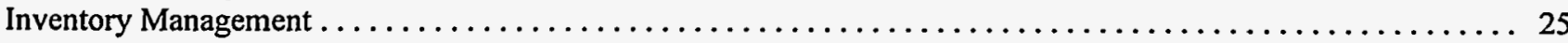

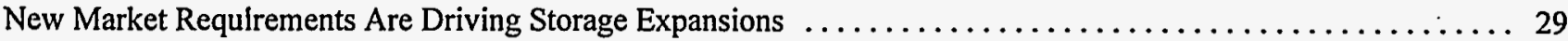

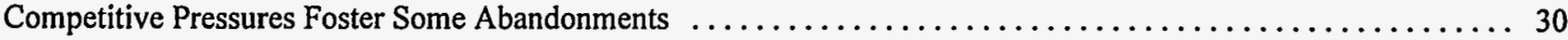

The Emphasis on Salt Cavern and Other High-Deliverability Storage $\ldots \ldots \ldots \ldots \ldots \ldots \ldots \ldots \ldots \ldots \ldots \ldots \ldots \ldots \ldots \ldots$

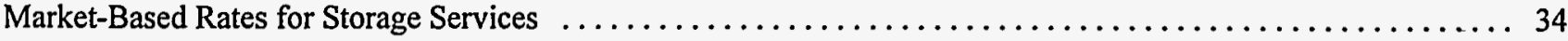

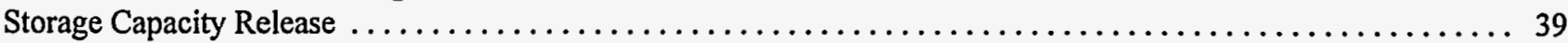

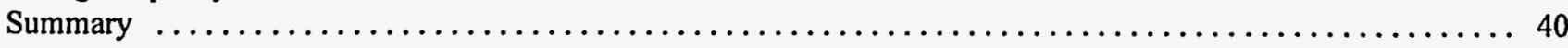

Appendices

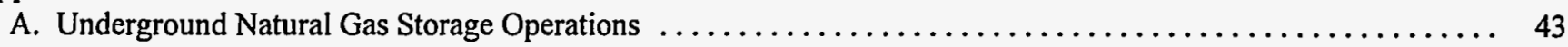

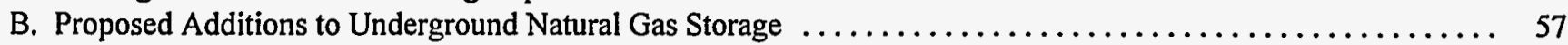

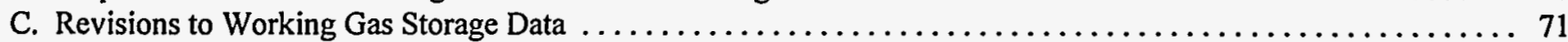

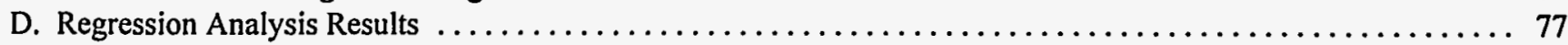




\section{Tables}

1. Monthly Natural Gas Injections, Withdrawals, and Working Gas Levels,

Heating Years, 1982-83 Through 1986-87 and 1989-90 Through 1993-94 .................. 27

2. Proposed New and Expansion Underground Storage Projects in the United States, 1994-1999 . . . . . . . . 31

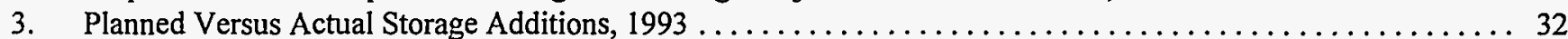

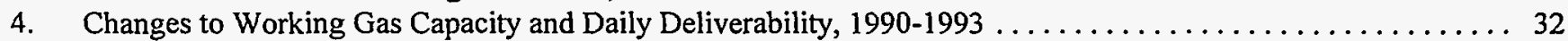

5. Storage Service Providers Seeking to Charge Market-Based Rates $\ldots \ldots \ldots \ldots \ldots \ldots \ldots \ldots \ldots \ldots \ldots \ldots$

\section{Figures}

1. Storage Facilities Are Heavily Concentrated Near Major Eastern Markets $\ldots \ldots \ldots \ldots \ldots \ldots \ldots \ldots \ldots \ldots$

2. January 1994 Storage Withdrawals Were the Second Highest on Record $\ldots \ldots \ldots \ldots \ldots \ldots \ldots \ldots \ldots \ldots$

3. Almost 1.3 Trillion Cubic Feet of Gas Was Withdrawn During the Bitter Cold of January and February 1994 ... 5

4. An Active Storage Industry Enables Production to Vary Much Less Than Consumption on a Monthly Basis . ... 8

5. Recently, Seasonality in Production Appears to Have Declined as Withdrawals and Imports Have Increased .... 9

6. By 1993, Average Variability in Production Was About Half of Its 1986 Value . . . . . . . . . . . . . . . . . . 9

7. During the Heating Seasons in the 1990's, Storage Withdrawals and Imports Have Generally Increased

as a Percent of Consumption While Production Has Declined $\ldots \ldots \ldots \ldots \ldots \ldots \ldots \ldots \ldots \ldots$

8. Storage Levels and Spot Prices Are Not Clearly Related $\ldots \ldots \ldots \ldots \ldots \ldots \ldots \ldots \ldots \ldots \ldots \ldots \ldots \ldots \ldots 12$

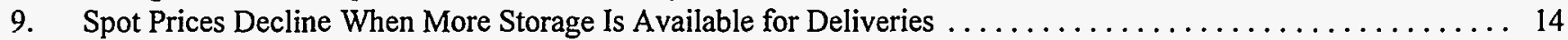

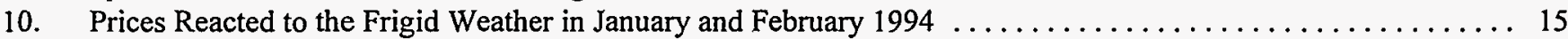

11. Average of Temperatures for Four Cities Plummets in Mid-January $\ldots \ldots \ldots \ldots \ldots \ldots \ldots \ldots \ldots \ldots \ldots \ldots$

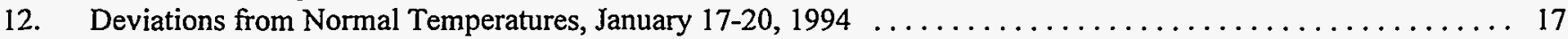

13. The Premium Value of Gas Increases as Weather Becomes Colder $\ldots \ldots \ldots \ldots \ldots \ldots \ldots \ldots \ldots \ldots \ldots$

14. Cold Weather Index Shows Persistence of Severe Temperatures $\ldots \ldots \ldots \ldots \ldots \ldots \ldots \ldots \ldots \ldots \ldots \ldots$

15. Henry Hub and Iroquois Have Largest Increase in Spot Prices, January $13-24,1994 \ldots \ldots \ldots \ldots \ldots \ldots .21$

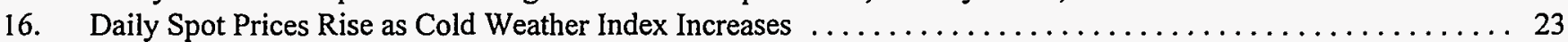

17. As Order 636 Takes Effect, Storage Volumes Owned by Interstate Pipeline Companies Continue to Decline ... 26

18. Utilization of Storage Facilities Has Increased During the Heating Seasons $\ldots \ldots \ldots \ldots \ldots \ldots \ldots \ldots \ldots 28$

19. Storage Capacity Utilization in 1994 Reversed the Declining Trend, Moving Higher Than 1991 Levels

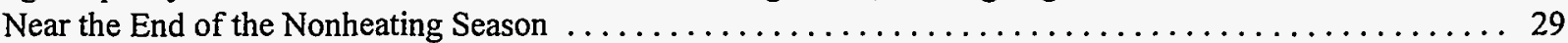

20. Independent Operators Are Projected to Play a Larger Role in Storage by the End of the Decade ........ 31

21. Withdrawals from Salt Cavern Storage Show Steady Increases, With Substantial Gains in Nonheating Seasons .. 35 


\section{Executive Summary}

Underground storage is a vital part of the natural gas industry. The ability to store gas ensures reliability during periods of heavy demand by supplementing pipeline capacity. Storage also enables greater system efficiency by allowing more level production and transmission flows. End-use customers gain from this increased efficiency with reduced overall costs of service.

This report explores the significant and changing role of storage in the industry by examining the value of natural gas storage; short-term relationships between prices, storage levels, and weather; and some longer term impacts of the Federal Energy Regulatory Commission's (FERC) Order 636. Some of the highlights of the report include the following:

- Expected storage requirements and spot prices are strongly related during the heating season. High prices in the spot market are associated with low levels of storage relative to expected deliveries. As temperatures drop below normal, storage withdrawals increase and gas prices can rise dramatically. The premium value of having gas available for immediate delivery during periods of stress can be greater than $\$ 1.00$ per million Btu. During other times of the year, the relationship between storage and spot prices is much less direct as weather and pipeline capacity utilization are of less concern.

- Regulatory changes during the past decade have resulted in significant changes in storage operations. Higher utilization of storage facilities is evident throughout the year in both injection and withdrawal activities. However, new programs for storage markets, such as market-based rates and secondary markets for storage capacity, have experienced limited growth.

- Proposed capacity additions through the end of the decade could increase the ability of the storage industry to deliver gas from storage on a peak day by almost 31 percent from the level in 1993. About onethird of the proposed additions to working gas capacity are for high-deliverability salt cavern storage projects, which allow greater flexibility for both withdrawals and injections throughout the year than is available in more traditional facilities. This flexibility is increasingly valuable in addressing new market requirements.

The key role that storage plays in the natural gas market was demonstrated during January and February 1994 when severe weather placed enormous demands upon the industry. The additional storage capacity placed in service since the frigid
December of 1989 played a role in allowing the successful delivery of gas to the markets during January 1994. The ability to deliver gas from storage has increased by nearly 10 percent over levels available in December 1989.

\section{The Role of Natural Gas Storage}

Natural gas consumption is strongly influenced by weather, with levels during the heating season (November through March) being about 55 percent higher per month than during the nonheating season. This pattern is driven by the heavy use of natural gas for space heating in the residential and commercial sectors. For example, monthly residential consumption during the heating season averages three times higher than during the nonheating season.

Storage, particularly that which is accessed directly by local distribution companies, gives great flexibility to the distribution system, allowing it to respond quickly to sudden shifts in demand. The severe temperature conditions during January 1994 provide a good example of this flexibility. As average temperatures in much of the Northeast and Midwest plummeted to 20 degrees or more below normal, many companies withdrew record amounts of gas from storage. For example, ANR Pipeline Company, one of the largest providers of storage services, withdrew a record 3.3 billion cubic feet of gas from its Michigan storage fields two days in a row, exceeding its previous peak by 18 percent.

The industry currently has the capability to store approximately 8 trillion cubic feet (Tcf) of natural gas in 375 storage sites around the country (Figure ES1). Of this, about 46 percent ( $3.7 \mathrm{Tcf}$ ) is considered working gas storage that can be withdrawn as necessary to meet demand requirements. On a peak day, the industry has the capability to deliver more than 120 billion cubic feet of natural gas to consumers, and underground storage can supply as much as half of this demand. To service the heavy heating load in the Northeast and Midwest, more than half of the country's working gas capacity is located east of the Mississippi River.

The gas industry is willing to invest in storage because of its considerable value in terms of increased efficiency, increased reliability of service, and, consequently, market growth. Historically, the major role of storage in production has been to smooth natural gas production between the peak and offpeak seasons by supplying places to store gas in the summer when gas consumption is low in major residential and 
Figure ES1. Storage Facilities Are Heavily Concentrated Near Major Eastern Markets

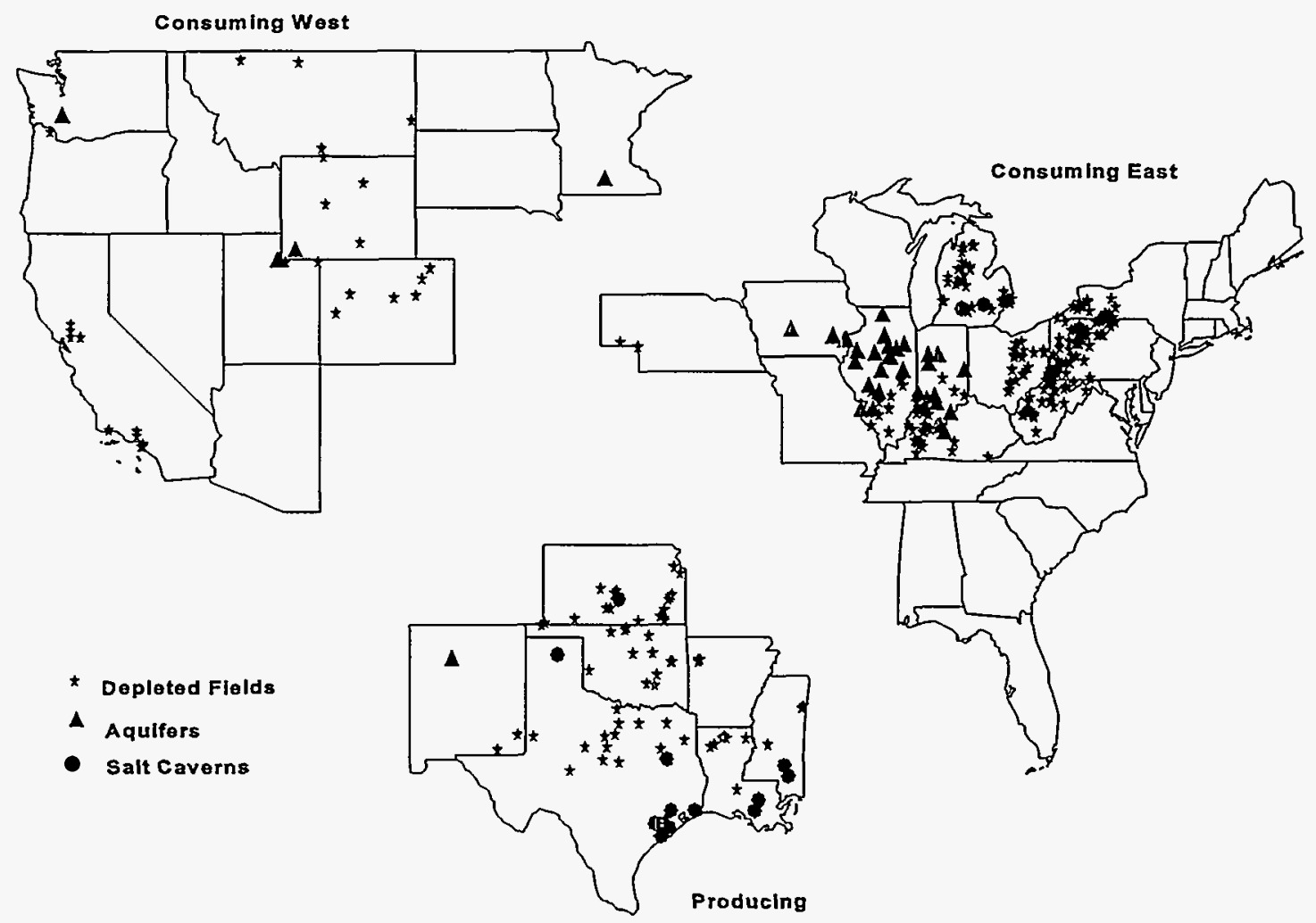

Note: Regions are those established by the American Gas Association.

Source: Energy Information Administration, Office of Oil and Gas, Natural Gas Pipeline Geographic Information System (November 1994).

commercial consuming regions. Underground storage has helped the gas industry reduce the variability in the amount of natural gas produced monthly. Without storage the natural gas industry would require more production wells to satisfy winter demand. This savings in production wells is viewed as an efficiency gain traceable to the availability of storage reservoirs. The availability of storage also allows pipeline companies to operate more efficiently by enabling them to function at a more constant level throughout the year, thus making better use of available pipeline capacity.

Some new aspects of storage are market-based rates for storage services, the release of storage capacity to third parties, and the use of storage to support transactions in the natural gas financial markets. The short-term influences of storage on the industry have become so important that the American Gas Association began releasing estimates of weekly levels of working gas on January 5, 1994. Prior to this, only the Energy Information Administration's monthly survey data were publicly available.

\section{Storage Activity and Wellhead Prices}

Storage levels and activities can significantly affect spot market prices. However, because storage is only one aspect of the supply picture, the relationship between changes in storage volumes and spot market prices is not always clear. Still, when extreme weather conditions occur during the heating season, withdrawals from storage comprise a larger proportion of supply to the market areas, and some measures of the potential impacts can be estimated.

During periods of severe weather or other stress conditions, the monetary value of natural gas held in storage can change 
significantly. For example, the spot price for gas in a given month is often relatively close to the average price of futures contracts for the next month. However, if temperatures suddenly plummet, the price of gas can far exceed that under a futures contract. The difference between the spot price and the futures price is defined as the "premium," an indicator of the value associated with having ready supplies of gas on hand in storage sites.

Prices during the unprecedented cold spell that hit the eastern United States in January 1994 provide a good illustration of the magnitude the premium can reach (Figure ES2). On January 18, the Monday following the weekend the cold front hit, spot prices at the Henry Hub (the delivery point for the futures market) soared, raising the premium to nearly $\$ 0.80$ per million Btu (MMBtu). The weather abated somewhat, then was predicted to turn cold again, causing the premium to peak at \$1.12 per MMBtu on February 2.

Just as price changes affect the value of gas in storage, storage activity can affect prices. Storage levels exhibit the strongest influence on wellhead prices during the latter part of the heating season, when the entire gas industry can be expected to experience the greatest stress. Regression analysis using data from 1991 through 1994 shows that 59 percent of the variability in monthly spot prices at the Henry Hub was associated with a measure of the storage system's readiness to make deliveries. Higher levels of readiness, as indicated by a higher level of gas in storage relative to expected deliveries the next month, are associated with lower spot market prices. (Expected deliveries are monthly consumption levels during the previous year.)

Interest in the impacts of storage activity has increased because of the ways in which storage activity has changed in recent years. Many of these changes are market driven while others are the direct result of the implementation of FERC Order 636 in 1993.

\section{Changes in Storage Operations}

Many aspects of storage operations were changing even before Order 636 became effective November 1, 1993. Some of these changes occurred in anticipation of the order as the proposed rulemaking was widely debated throughout the industry.

One area of change has been in inventory management. The separate pricing of storage services and the existence of a gas

Figure ES2. The Premium Value of Gas in Storage Rose Dramatically in Early 1994

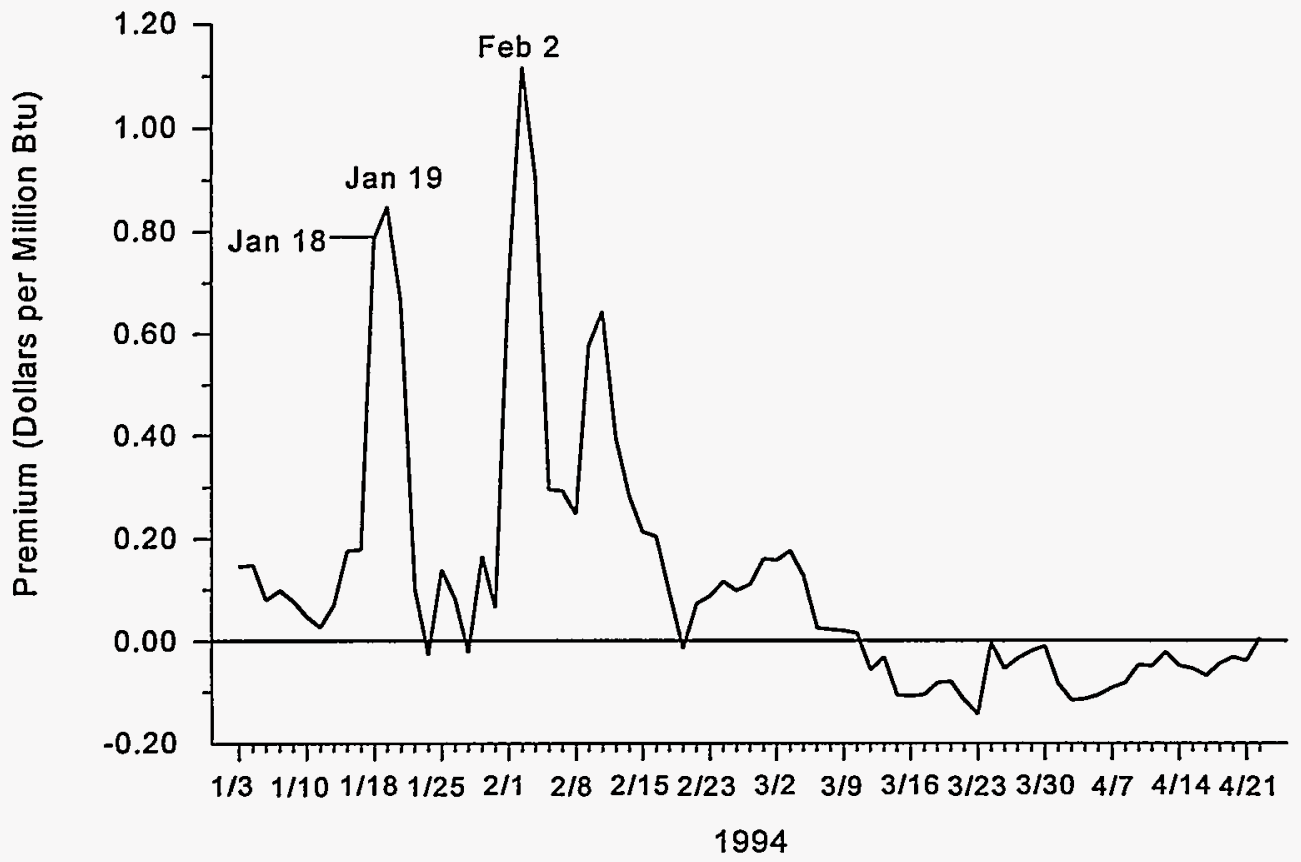

Note: The premium is the difference between the Henry Hub spot price and the futures price for the expiring futures contract. Data are unavailable for weekends and holidays.

Sources: Energy Information Administration, Office of Oil and Gas: derived from: Henry Hub Spot Price: Pasha Publications Inc., Gas Daily and Futures Price: Commodity Futures Trading Commission, Division of Economic Analysis. 
futures market help the industry reduce the price risk of holding gas in storage. One way to do this is to increase the efficiency of storage operations so that less gas is exposed to price risk.

The industry has done this successfully in recent years. For heating years 1989-90 through 1993-94, average monthly injections and withdrawals per storage field increased (Table ES1). The change was most significant for injections during the heating season and for withdrawals during the nonheating season. Average injections during the heating season increased by 37 percent from the average during the mid-1980's, while working gas levels increased by 9 percent. Similarly, average withdrawals during the nonheating season increased by 47 percent while working gas levels increased by 10 percent.

Increased injections and withdrawals have occurred while the patterns of using working gas capacity have changed. Data for 1991 through 1993 show that the industry has been able to operate with declining proportions of working gas capacity filled during the summer months (Figure ES3). During 1994, however, the share of capacity filled monthly exceeded that of 1993 throughout the nonheating season, and by September it even exceeded the 1991 share. The 1994 nonheating season was the first under Order 636, and thus the first during which a significant amount of interstate storage came under the management of parties other than the pipeline companies. For the most part, these parties are local distribution companies, and it is not surprising that during this first year they may have filled, in aggregate, a higher portion of available capacity than did the pipeline companies. A decline in gas prices in late summer also may have encouraged the more rapid filling of storage.

Another area of change has been in the forces driving storage development. Such factors as the need to resolve pipeline imbalances quickly and the desire to take advantage of shortterm changes in gas prices have encouraged the construction of high-deliverability storage facilities such as salt caverns. More than one-third of the 21 existing salt facilities have been brought on line since 1991.

The greater deliverability of salt cavern storage, compared with either depleted field or aquifer facilities, can be seen in the plans for new storage construction proposed for 1994 through 1999 (Figure ES4). During this period, salt cavern facilities will account for only 28 percent of the total additions to capacity, yet they will provide 68 percent of the additional withdrawal capability.

The newest changes to affect the storage industry are marketbased rates for storage services and the development of a secondary market for storage capacity. Both have seen limited development as the industry and Federal regulators attempt to implement the first programs in each area. To receive permission to charge market-based rates, the applicant must demonstrate its lack of market power. This can be difficult except for those relatively smaller facilities in areas with substantial storage options already available. As of January 20,1995 , only 96 billion cubic feet of working gas capacity was subject to market-based rates; and of the applications FERC has approved, only two are for facilities that are operational.

Table ES1. Average Monthly Natural Gas Injections, Withdrawals, and Working Gas Levels, Heating Years, 1982-83 Through 1986-87 and 1989-90 Through 1993-94 (Million Cubic Feet)

\begin{tabular}{|c|c|c|c|c|c|c|c|c|c|c|c|c|}
\hline \multirow[b]{2}{*}{ Period } & \multicolumn{4}{|c|}{ Average Injections per Field } & \multicolumn{4}{|c|}{ Average Withdrawals per Field } & \multicolumn{4}{|c|}{ Average Working Gas per Field } \\
\hline & $\begin{array}{l}\text { 1982-83 } \\
\text { Through } \\
1986-87\end{array}$ & $\begin{array}{l}1989-90 \\
\text { Through } \\
1993-94\end{array}$ & $\begin{array}{l}\text { Volume } \\
\text { Change }\end{array}$ & $\begin{array}{l}\text { Percent } \\
\text { Change }\end{array}$ & $\begin{array}{l}1982-83 \\
\text { Through } \\
1986-87\end{array}$ & $\begin{array}{l}1989-90 \\
\text { Through } \\
1993-94\end{array}$ & $\begin{array}{l}\text { Volume } \\
\text { Change }\end{array}$ & $\begin{array}{l}\text { Percent } \\
\text { Change }\end{array}$ & $\begin{array}{l}1982-83 \\
\text { Through } \\
\text { 1986-87 }\end{array}$ & $\begin{array}{l}1989-90 \\
\text { Through } \\
1993-94\end{array}$ & $\begin{array}{l}\text { Volume } \\
\text { Change }\end{array}$ & $\begin{array}{l}\text { Percent } \\
\text { Change }\end{array}$ \\
\hline \multicolumn{13}{|l|}{ Nonheating } \\
\hline Season & 757 & 906 & 149 & 20 & 126 & 185 & 59 & 47 & 5,891 & 6,451 & 560 & 10 \\
\hline \multicolumn{13}{|l|}{ Heating } \\
\hline Season & 187 & 257 & 70 & 37 & 1,099 & 1,217 & 118 & 11 & 5,247 & 5,734 & 487 & 9 \\
\hline Heating Year & 520 & 642 & 122 & 23 & 531 & 644 & 113 & 21 & 5,623 & 6,160 & 537 & 10 \\
\hline
\end{tabular}

Note: Before 1991, data were available only on a company-wide basis. For field-level data before January 1991, company-level data were apportioned based on the January 1991 ratio of the field's working gas capacity to the company total working gas capacity. Only fields active throughout the 1982-1993 period were included. A heating year is from April of one year through March of the next year; for example April 1982 through March 1983 is the 1982-83 heating year. A nonheating season is from April through October of one year. A heatıng season is from November of one year through March of the next year; for example November 1982 through March 1983 is the $1982-83$ heating season.

Source: Energy Information Administration. 1982-83 through 1990-91: ElA-191/FERC-8, "Underground Gas Storage Report." $1991-92$ through 1993-94: EIA-191, "Underground Gas Storage Report. 
Figure ES3. Storage Capacity Utilization Declined in the Early 1990's, But Increased in 1994

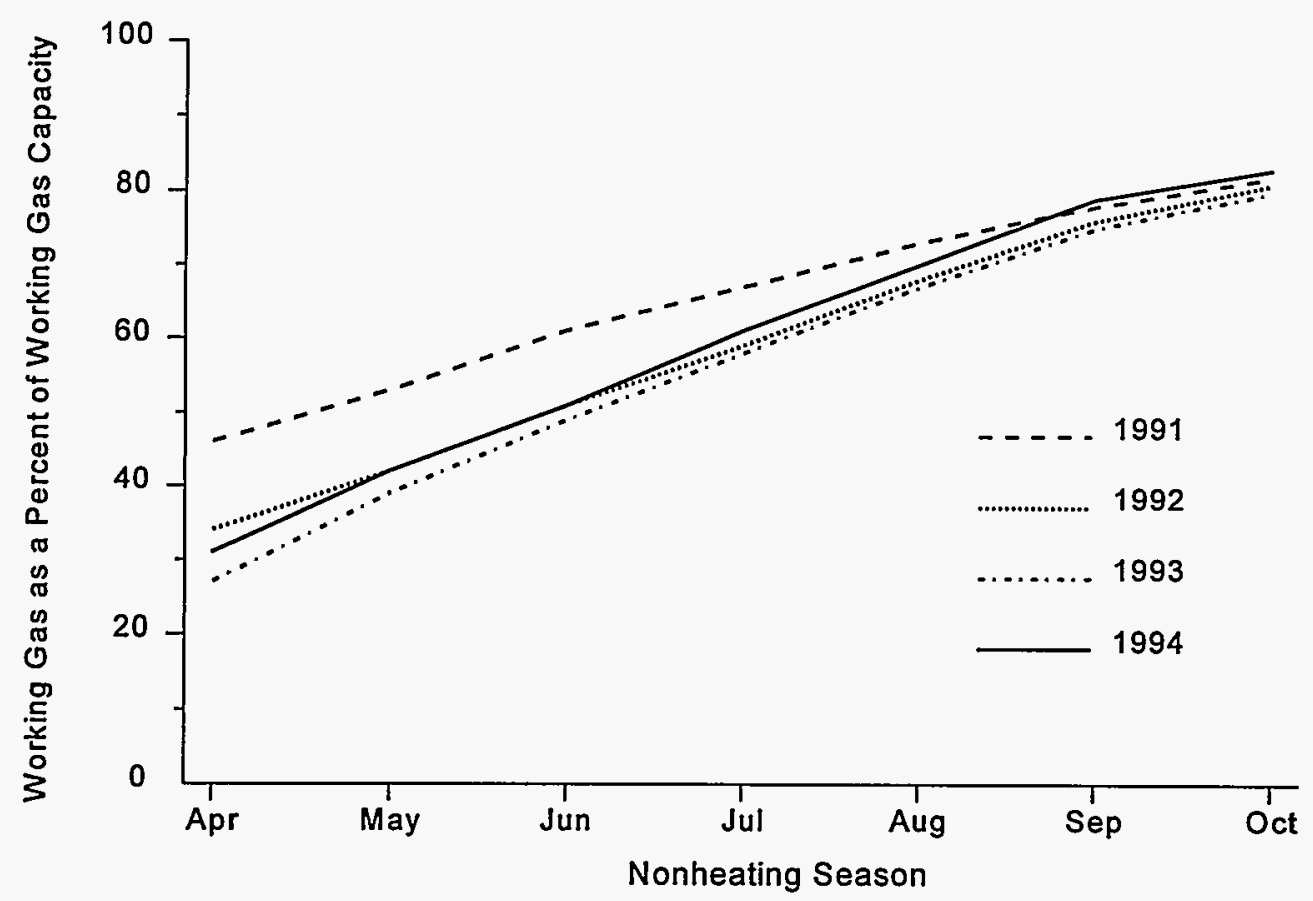

Source: Energy Information Administration, ElA-191, "Underground Gas Storage Report."

Figure ES4. Proposed Salt Facilities Will Provide More Withdrawal Capability Relative to Total Capacity Than Depleted Fields

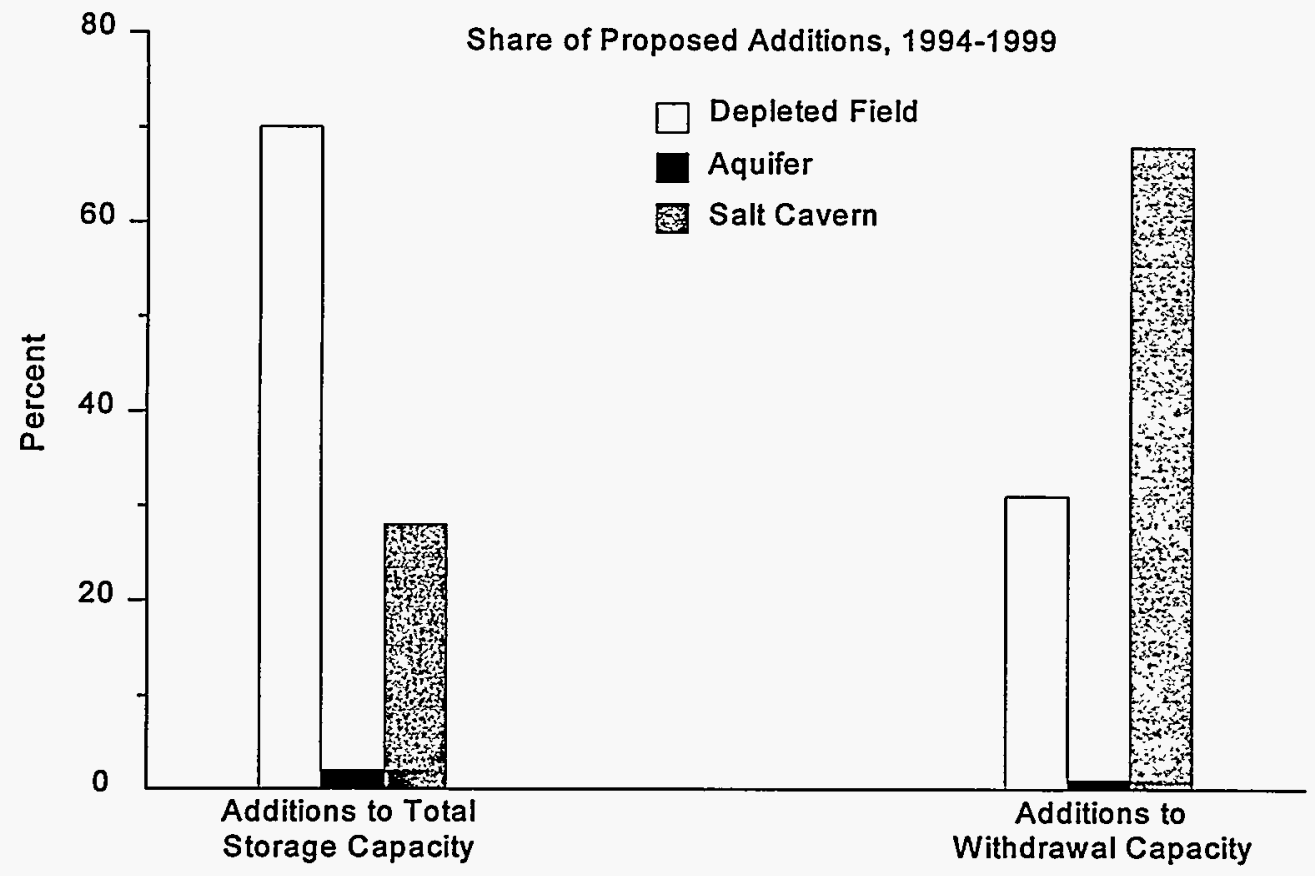

Source: Energy Information Administration, Office of Oil and Gas, "Proposed Natural Gas Storage Projects," data base as of October 31, 1994, based on Federal Energy Regulatory Commission filings and information from various industry news sources. 


\section{Summary}

The factors influencing the relationship between price and storage vary throughout the year as the immediacy of the need for supplies from storage changes between the heating and nonheating seasons. During the heating season, however, the relationship between storage and movements in spot prices is strong. Thus, in the short term, the relationship between storage levels and expected deliveries during the heating season is important in explaining changes on the spot market. Over the longer term, there are other significant factors that influence the operation of the industry and pricing of storage services as well. In particular, regulatory changes during the past decade have resulted in greater use of storage facilities, suggesting efficiency gains throughout the industry. 


\section{Importance of Storage in the Gas Industry}

Underground storage is a vital part of the natural gas industry. The ability to store gas ensures supply reliability during periods of heavy demand by supplementing pipeline capacity and serving as backup supply in case of an interruption in wellhead production. Storage also allows load balancing of daily throughput levels on pipelines, which is necessary to ensure smooth operation of the pipeline system. Moreover, it enables greater system efficiency: instead of satisfying winter demand by adding new production facilities, the industry can place gas in storage during the summer and thus maintain production at a much more constant level throughout the year. A relatively recent development in the use of storage is to manage inventory levels to take advantage of expected price movements and to support futures market trading.

The cost of storage services can significantly influence what customers pay for gas, both at the wellhead and at the citygate. For those customers requiring storage services, these services can easily add a dollar per thousand cubic feet or more to the price of gas.' On a daily basis, the amount of gas in storage in comparison with planned levels can affect the current price of gas at the wellhead. Over the longer term, the availability of storage gas in market areas allows more efficient use of the pipeline system, which ultimately results in lower gas prices than would be possible without storage.

Storage activity and price are strongly affected by weather, which is a key factor in the annual planning cycle that companies undertake to ensure that adequate supplies are available to meet customer requirements. The industry injects large amounts of gas into underground storage reservoirs from April through October. During these months, gas demand declines as temperatures turn milder and spaceheating needs subside. Thus the large interstate pipelines have additional space available for shipping gas to underground storage reservoirs.

During the heating season, the industry combines supplies from the producing regions, including imported supplies, with supplies from underground storage to meet most customer demands. In addition, the industry operates peaking facilities, such as propane-air plants, in market areas to fulfill unusual peaks in consumption or to offset a temporary interruption in supplies.

\footnotetext{
'Energy Information Administration, Natural Gas 1994: Issues and Trends, DOE/EIA-0560(94) (Washington, DC, July 1994), p. 67.
}

The industry currently has the capability to store approximately 8 trillion cubic feet (Tcf) of natural gas in 375 storage sites around the country (Figure 1). Of this, about 46 percent $(3.7 \mathrm{Tcf})$ is considered working gas storage that can be withdrawn as necessary (see box, p. 3). On a peak day, the industry has the capability to deliver more than 120 billion cubic feet of natural gas to consumers, ${ }^{2}$ and underground storage can supply as much as half of this demand. ${ }^{3}$ To meet the substantial heating load in the Northeast and Midwest, more than half of the country's working gas capacity is located east of the Mississippi River. Approximately 28 percent is located in the major producing region, whereas only 16 percent is located in the West where much of the population lives in areas with relatively moderate climate (Figure 1).

In the longer term, storage activity is also influenced by institutional arrangements, such as who owns the gas in storage, who has rights to use the storage facility, and the possibility of trading these rights. Regulatory changes initiated in the mid-1980's have transformed the once highly regulated industry to one in which competitive factors dominate the market. These regulatory changes have significantly affected storage operations and the type of storage facilities being put in place. In particular, Federal Energy Regulatory Commission (FERC) Order 636 mandated that by 1993 (1) storage service be unbundled, that is, offered as a distinct service, separately charged and itemized, (2) customers be offered greater access to underground storage capacity or the right to use space in storage reservoirs, and (3) customers be given the opportunity to sublease any of their contracted storage capacity. With customers now responsible for developing their own contract services and arrangements, storage has become much more important in the daily business operations of all industry sectors.

During its first heating season under the new, less regulated, "open-access" environment, the industry was tested by extreme weather conditions in January 1994, which prompted near-record storage withdrawals (see box, p. 4). The extensive storage capability in market areas, combined with more operational and contractual flexibility, allowed sufficient gas to flow to meet record monthly consumption levels.

\footnotetext{
${ }^{2}$ The 120 billion cubic feet per day refers to the physical capability of the industry to deliver gas. It is a measure of the peak-day design capacity of the entire system, including pipeline, storage, and peak-shaving facilities. National Petroleum Council, The Potential for Natural Gas in the Unted States: Transmission and Storage (Washington, DC, December 1992).

${ }^{3}$ Based on an estimate of deliverability' from storage of 68 billion cubic feet per day (Table 4, Chapter 3 ).
} 
Figure 1. Storage Facilities Are Heavily Concentrated Near Major Eastern Markets

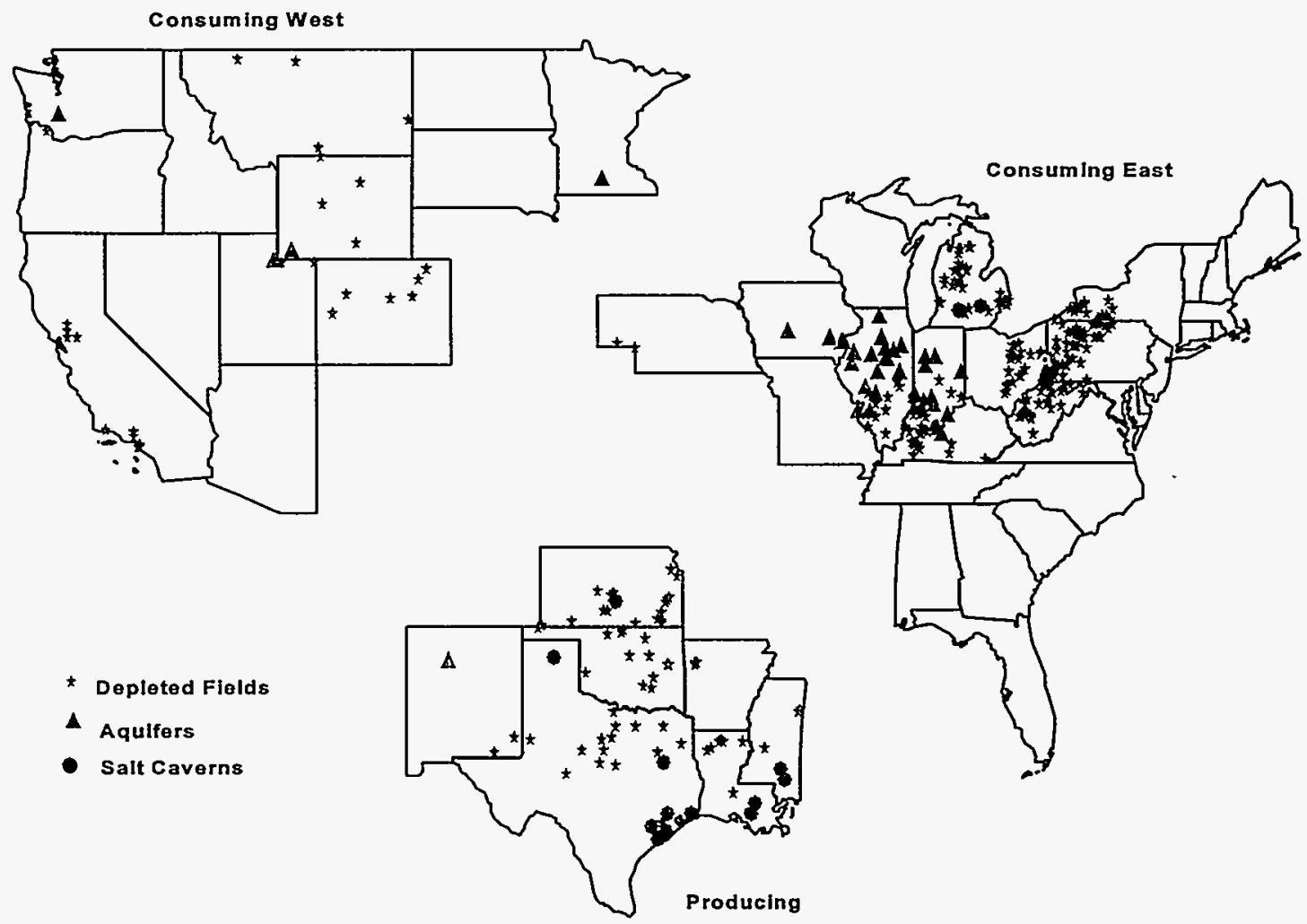

\begin{tabular}{|c|c|c|c|c|c|}
\hline \multicolumn{2}{|c|}{ Consuming East Region } & \multicolumn{2}{|c|}{ Consuming West Region } & \multicolumn{2}{|c|}{ Producing Region } \\
\hline State & $\begin{array}{c}\text { Working Gas } \\
\text { Capacity } \\
\text { (Bcf) }\end{array}$ & State & $\begin{array}{c}\text { Working Gas } \\
\text { Capacity } \\
\text { (Bcf) }\end{array}$ & State & $\begin{array}{c}\text { Working Gas } \\
\text { Capacity } \\
\text { (Bcf) }\end{array}$ \\
\hline lowa & 98 & California & 222 & Arkansas & 3 \\
\hline Illinois & 317 & Colorado & 57 & Kansas & 120 \\
\hline Indiana & 35 & Minnesota & 2 & Louisiana & 285 \\
\hline Kentucky & 105 & Montana & 203 & Mississippi & 52 \\
\hline Maryland & 16 & Oregon & 7 & New Mexico & 64 \\
\hline Michigan & 617 & Utah & 54 & Oklahoma & 133 \\
\hline Missouri & 8 & Washington & 15 & Texas & 369 \\
\hline Nebraska & 15 & Wyoming & 46 & & \\
\hline New York & 75 & & & & \\
\hline Ohio & 238 & & & & \\
\hline Pennsylvania & 329 & & & & \\
\hline West Virginia & 209 & & & & \\
\hline Total & 2,062 & & 606 & & 1,026 \\
\hline Percent of U.S. Total & 56 & & 16 & & 28 \\
\hline U.S. Total & 3,694 & & & & \\
\hline
\end{tabular}

Bcf $=$ Billion cubic feet.

Note: Regions are those established by the American Gas Association.

Source: Energy Information Administration, Office of Oil and Gas, Natural Gas Pipeline Geographic Information System (November 1994). 


\section{Storage Measures}

Several measures are used throughout the report to assess the capability of the industry to deliver gas from storage at any point in time. They are usually expressed as volumes of gas and are normally reported at a pressure base of 14.73 psia and a temperature of 60 degrees Fahrenheit.

Total capacity is the maximum volume of gas that can be stored in an underground storage facility and is determined by the physical characteristics of the reservoir. For storage facilities under the jurisdiction of the Federal Energy Regulatory Commission, a facility's "certificated capacity" and total capacity are one and the same.

Base gas (or cushion gas) is the volume of gas needed as permanent inventory in a storage reservoir to maintain adequate pressure and deliverability rates throughout the withdrawal season. The amount of base gas required in a reservoir depends on how the operator intends to operate or manage the storage facility.

Working gas capacity is total capacity minus base gas.

Working gas is the volume of gas in the reservoir above the designed level of the base gas. It is gas that is temporarily stored in a reservoir with the express purpose of being withdrawn at a future date, usually (in the case of baseload facilities) during the heating season. The amount of working gas is always less than or equal to working gas capacity.

Deliverability is a measure of the amount of gas that can be delivered from a storage facility in a given length of time. Also referred to as the deliverability rate, withdrawal rate, or withdrawal capacity, deliverability is most often measured in terms of million cubic feet per day. The deliverability of a given storage facility is variable, and depends on factors such as the amount of gas in the reservoir at any particular time, which dictates the pressure within the reservoir, compression capability available to the reservoir, the configuration and capabilities of surface facilities associated with the reservoir, and other factors. In general, a facility's deliverability rate varies directly with the amount of working gas in the reservoir: it is at its highest when the reservoir is most full and declines as working gas is withdrawn.

Recent restructuring of the gas industry has been influenced not only by changes in regulation by FERC and other regulatory bodies, but also by the development of new markets. In particular, the natural gas futures market has led to new sectors of the gas industry and to new ways certain sectors conduct their business. Marketing companies, the major growth sector in the gas industry in the past 10 years, use the futures market as a means of establishing the price for mid-term contracts and as a means to hedge price risk for both short-term and mid-term supply contracts. ${ }^{4}$ The futures market can also be used to hedge the price risk associated with having gas in storage.

This report discusses the important role of storage in the natural gas market and how it affects the production, transmission, and pricing of natural gas. This chapter highlights the unique qualities of natural gas as a commodity and how the ability to store gas adds value. Chapter 2 examines the short-term characteristics of the market, specifically the relationship between storage and price relative to expected storage levels and weather, using some daily data from the severe cold spell of January 1994. This attention to daily data brings into focus important issues, such as shortterm shifts in price, that would otherwise be obscured. Chapter 3 addresses the longer term aspects of the market, discussing how the regulatory and market changes during the past few years have affected storage operations and the type of storage facilities being put in place. In particular, it highlights the increasing role of salt cavern storage facilities, the status of market-based rates for storage, and the development of a secondary market for storage capacity.

\footnotetext{
'Energy Information Administration, Natural Gas 1994: Issues and Trends, DOE/EIA-0560(94) (Washington, DC, July 1994).
} 


\section{Storage Played a Key Role During the Record Cold in January 1994}

The severe winter of 1993-94 placed enormous demands upon the natural gas industry. Record cold temperatures and heavy snowfall in the Northeast and Midwest during January 1994 led to record monthly natural gas demand, with consumption nationwide reaching 2,538 billion cubic feet $(\mathrm{Bcf}), 10$ percent higher than during the previous January. Storage facilities were extensively used to respond to the immediate needs of space-heating customers (Figure 2). Many companies reached all-time daily withdrawal and sendout levels, particularly during the third week of January. On January 19, Consumers Power, Michigan's largest gas and electric utility, and Michigan Consolidated delivered record volumes (3.1 and 2.5 Bcf, respectively) of which about 70 percent was from storage. On both January 18 and 19, ANR Pipeline withdrew a record 3.3 Bcf per day from its Michigan fields-almost 4 percent of working gas levels at the beginning of the heating season and substantially more than the previous peak of $2.8 \mathrm{Bcf}$ per day.

Working gas levels were drawn down sharply during the month with withdrawals totaling 756 Bcf, equivalent to 30 percent of gas consumed. During the extremely cold third week of the month, the volume of total working gas in storage dropped 253 $\mathrm{Bcf}$, as estimated by the American Gas Association (AGA) (Figure 3). This change was 33 to 54 percent greater than the decline in each of the previous 2 weeks and was 11 percent of the working gas in storage on December 31 . The most extreme drawdowns in January occurred in the AGA's Consuming East Region (mainly the gas-consuming States east of the Mississippi River), where estimated net withdrawals of 489 Bcf were approximately 36 percent of the gas consumed. The interstate pipeline and local distribution companies (LDC's) serving this area rely on storage withdrawals for a substantial portion of supply during the heating months and have extensive storage facilities already in place. In the producing States, during the heating season, storage facilities are used primarily to balance flows on main interstate transmission lines. However, in the single week from January 14 to 21, working gas levels in the Producing Region declined significantly (76 $\mathrm{Bcf}$ ), showing that producers and marketers were relying on storage as well as wellhead production from the region to meet gas demands. This drop in the level of working gas was 49 to 90 percent greater than the decline that occurred in each of the previous 2 weeks in this region.

Markets in the West are less weather-sensitive and seasonal storage requirements are correspondingly lower. In addition, extensive transmission capacity is now available into California and other major western markets. The Consuming West Region had the lowest level of working gas in storage during January, and activity was unaffected by the eastern cold spell. The region's decline in working gas from January 14 to 21 was only $14 \mathrm{Bcf}-$ lower than the 16 to $25 \mathrm{Bcf}$ declines that occurred in this region during each week of February.

Overall storage withdrawals during January 1994 were 27 percent higher than during the previous January and second only to the 822 Bcf withdrawn in December 1989 when frigid weather in the supply region caused some disruptions in production. Today's pipeline system is quite different from that in 1989 , with much more import capacity available from Canada and more system flexibility to enable gas to move quickly during peak demand periods. For example, the large Iroquois Pipeline in the Northeast was designed to handle peak summer loads for electricity generation and thus has sufficient capacity during the winter to allow extensive linepacking, which is a method for using the pipeline for short-term gas storage. When emergency supplies were needed by Consolidated Edison of New York during January 1994, Iroquois was able to deliver gas from linepacking, and several companies were able to divert their supplies to Consolidated Edison and then replace them with propane and liquefied natural gas from storage.

The additional storage capacity placed in service since 1989 also played a role in supporting the successful delivery of gas to markets during January 1994. From 1990 through 1993, 136.5 Bcf of working gas capacity and 5.7 Bcf per day of deliverability were added, representing increases of 3.8 and 9.2 percent, respectively, over levels in 1989 . 
Figure 2. January 1994 Storage Withdrawals Were the Second Highest on Record

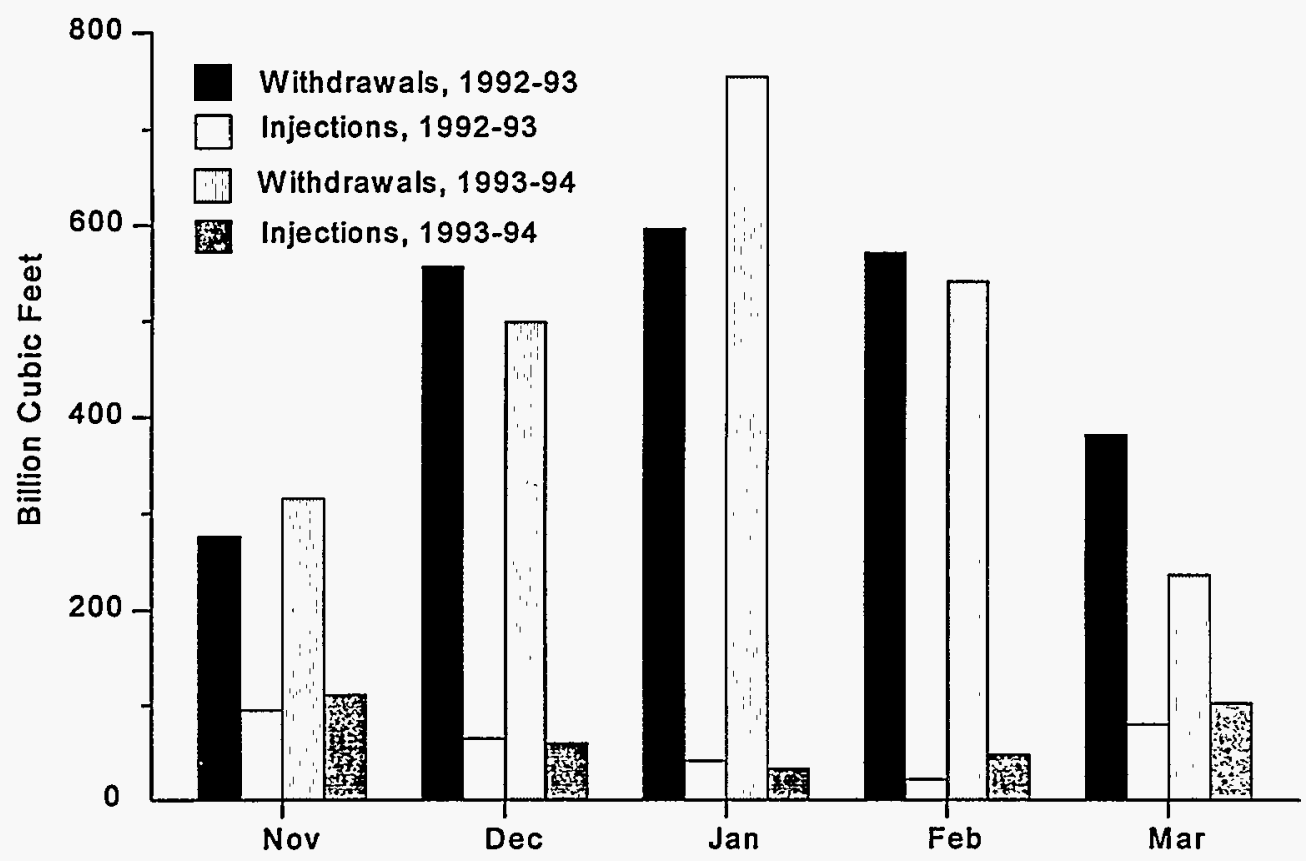

Note: The highest storage withdrawals (822 billion cubic feet) occurred in December 1989.

Source: Energy Information Administration, EIA-191, "Underground Gas Storage Report."

Figure 3. Almost 1.3 Trillion Cubic Feet of Gas Was Withdrawn from Storage During the Bitter Cold of January and February 1994

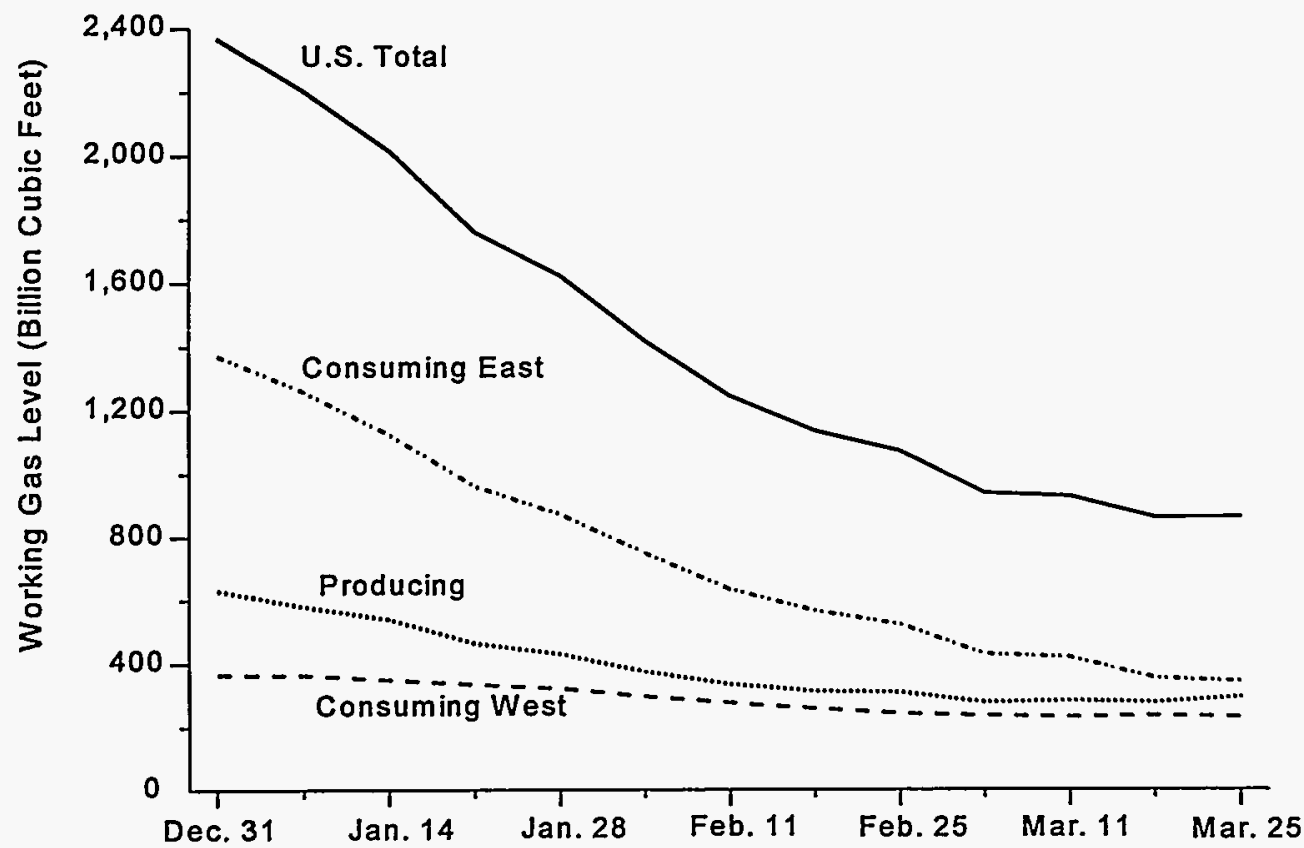

Note: The Producing Region consists of New Mexico, Kansas, Oklahoma, Texas, Arkansas, Louisiana, and Mississippi. The Consuming East Region consists of all States east of the Mississippi River and Nebraska, lowa, and Missouri. The Consuming West Region consists of all other lower 48 States.

Source: American Gas Association. 


\section{Natural Gas as a Commodity and the Role of Storage}

Regulatory restructuring during the past 15 years has fostered the development of natural gas as a commodity distinct from the bundled sales and transportation service previously provided by pipeline companies. Several events contributed to this development, including:

- The deregulation of wellhead markets

- The development of active spot markets scattered throughout the United States

- The opening up of the transportation system, which allows gas to flow more freely between markets

- The growth of the futures market, which enables buyers and sellers to obtain information on the expected price of gas throughout the day.

These factors have contributed to making natural gas similar to other commodities such as corn, sugar, copper, and cotton in that prices for these commodities are:

- Dependent on current and expected supply and demand conditions

- Readily available on a daily basis from printed and electronic media

- Indicative of broad and regular trade on public markets throughout the country.

In other ways, however, natural gas as a commodity has some relatively unique characteristics that affect the price consumers pay for the commodity and also the size of the market. In contrast to agricultural foodstuffs, for example, natural gas is produced throughout the year. Demand for gas on the other hand is highly variable throughout the year and depends greatly on the weather, whereas demand for most commodities is relatively constant during the year.

These different patterns of supply and demand for natural gas have resulted in a much more important role for storage than in most other commodity markets. Moreover, underground storage operations interact with all phases of the natural gas market.

- Storage smooths the production of gas, which continues throughout the year. Historically, the major role of storage in production has been to smooth natural gas production between the peak and off-peak seasons by supplying places to store gas in the summer when the use of gas is low in major residential and commercial consuming regions. The smoothing of production reduces the cost of gas to end-use customers.

- Storage withdrawals help satisfy sudden shifts in demand and supply caused by weather. Changes in the weather can greatly influence gas demand. Extremely cold weather throughout the United States, including in the major gas-producing areas, may also influence the supply of gas if well freezeups occur. Thus, weather can influence the price of gas through both supply and demand effects. The availability of stored gas can help consumers avoid the high cost of gas at these times. Thus, stored gas is used to supplement gas from production sites and also as the primary source of natural gas for end-use markets at such critical times.

- Underground storage operations are closely coordinated with the entire gas distribution system. Underground storage of gas is unique in comparison with other commodities in terms of its integration with the distribution system to maintain overall system integrity. Storage reservoirs are used as a convenient place to store gas when more gas is moving along pipeline systems than currently needed, and a convenient place to obtain gas when gas flow on the pipeline system is insufficient to maintain the pressure needed to sustain the system's deliverability capability. Stored gas is also used to adjust a customer's scheduled receipts and deliveries of gas from a pipeline company. Thus, storage is used to balance the system. The capability of storing gas underground in producing and in consuming regions has great inherent value to the gas industry.

The development of natural gas as a commodity has also influenced the way storage is used. With the development of active spot and futures markets, it is now possible regularly to adjust purchase decisions to price conditions. ${ }^{5}$ For example, buyers of gas are now encouraged to purchase amounts of gas that exceed planned levels and place the gas in storage if prices suddenly drop from expected levels. By doing this they expect to be able either to sell the gas at a higher price in the future or to avoid the expected higher cost of gas at a later date. These responses tend to temper price increases and to shorten the time during which high prices are sustained.

\footnotetext{
${ }^{5}$ The development of futures markets has also influenced decisionmaking in other energy markets. See Charles Dale and John Zyren, "The Effects of Crude Oil Commoditization on Gasoline Markets," Atlantic Economic Journal, 3, 33 (September 1994), p. 89, and the references cited therein.
} 


\section{Value of Underground Storage}

The gas industry is willing to invest in storage because it provides considerable value in terms of increased efficiency, increased reliability of service, and consequently market growth. As previously stated, underground storage has helped the gas industry reduce the variability in the amount of natural gas produced monthly. Without storage the natural gas industry would require more production wells to satisfy demand. This savings in production wells is viewed as an efficiency gain traceable to the availability of storage reservoirs. Without storage the gas industry would also need to bring less cost-effective wells on line during the winter to satisfy the increase in winter demand. This increase in the operation of less efficient wells would increase the cost of delivered gas. Accordingly, the existence of adequate storage provides value to producers and to consumers through lower prices for gas.

The availability of storage also allows more efficient operation of the pipeline system. Without storage, pipelines would have little or no spare capacity during the winter, yet would be underutilized during the spring and summer when space-heating demands by households and businesses decline. Additional capacity would be required to satisfy winter demand, which would increase the fixed costs that are allocated to the per-unit price of gas. If these fixed costs were spread proportionately to the amount of sales, it would significantly increase the cost of gas in the winter. If the costs were spread evenly over sales throughout the year, it would raise the cost of gas significantly in the summer. One reason why the industry has invested in storage is that it helps reduce the amount of capital allocated to the building of pipeline systems. Part of the efficiency gains or value of storage can be expressed as the difference in the capital cost of the gas system with and without storage per unit of delivered gas. ${ }^{6}$

The availability of storage also helps pipeline companies control gas pressure in the pipeline system and optimize pipeline performance in terms of flowing the required amounts of gas to customers when needed. Thus, the delivery capability of the pipeline system is improved because of storage.

When average monthly variability in consumption of a commodity is much greater than average monthly variability in production, it suggests that storage plays a significant role

\footnotetext{
'Such calculations are actually made by companies when they are evaluating whether to add storage or pipeline facilities to their system to satisfy increased demand.
}

in the market. ${ }^{7}$ In these instances, monthly shifts in consumption are not only managed by varying monthly amounts of production but also by varying the amount of the commodity placed into and taken out of inventory (or in the case of natural gas, underground storage). The fact that monthly gas production varies much less than monthly gas consumption underlines the importance of storage in the natural gas industry (Figure 4). During the period from 1983 through 1993, the variability in production was less than 25 percent of the variability in consumption. ${ }^{8}$ The variability in production declined significantly during the period from 1989 through 1993 relative to the earlier period from 1983 through 1988, ${ }^{9}$ suggesting that the role of storage within the gas industry has grown (Figure 4). Some of the decline in consumption variability is explained by consumers continuing to use more efficient end-use equipment to cut peak demands during the winter. Another contributory factor was industrial demand for gas, which has increased dramatically during the summer since the late 1980 's, predominantly because of the increased number of independent power producers and electricity cogenerators that burn natural gas. ${ }^{10}$ Furthermore, natural gas demand for direct use in air-conditioners and other summer gas services continued to grow. " This increase in demand during the summer also tends to stabilize both production levels and the flow of gas along pipeline systems by providing markets for gas during off-peak periods when demand is generally much lower. Thus, some of the decline in the variability of production can be explained by a reduction in the variability of consumption.

Nonetheless, much of the decline in the seasonality of domestic production in the late 1980's and early 1990's is due to the combined influence of increased imports of gas from

\footnotetext{
${ }^{7}$ For additional discussion and references on both the role of inventories in reducing the variability in production and in satisfying the variability in consumption and the relationship between variability in production and variability in consumption or sales, see Ray C. Fair, "The ProductionSmoothing Model is Alive and Well," Journal of Monetary Economics, 24 (1989), pp. 353-370.

${ }^{8}$ For an examination of similar ratios for heating oil and other commodities, see Robert S. Pindyck, "Inventories and the Short-run Dynamics of Commodity Prices," RAND Journal of Economics, 25 (Spring 1994), pp. 141-159.

When the equality of the variances of monthly production for both sets of years was tested using an F-test, the hypothesis was rejected at the 5percent significance level.

${ }^{10}$ For the summer month of July between 1988 and 1994, deliveries to industrial, commercial, and residential customers grew from 418 to 618 billion cubic feet (Bcf), 109 to $140 \mathrm{Bcf}$, and 123 to $129 \mathrm{Bcf}$, respectively.

"Natural gas use at electric utilities grew by 74 billion cubic feet (Bcf) for the key air-conditioning load months of July and August in 1993. This is a large increase from the year-earlier level and from the average for the 10 years between 1983 and 1992. Much of this increase $(58 \mathrm{Bct})$ occurred in Texas, thus helping to smooth production in that year. However, the change in production during the previous 5 years did not exhibit any trend and ranged between -42 and $39 \mathrm{Bcf}$. Thus, natural gas use at electric utilities has not made a systematic contribution to the smoothing of production that has occurred in the past several years.
} 
Figure 4. An Active Storage Industry Enables Production to Vary Much Less Than Consumption on a Monthly Basis

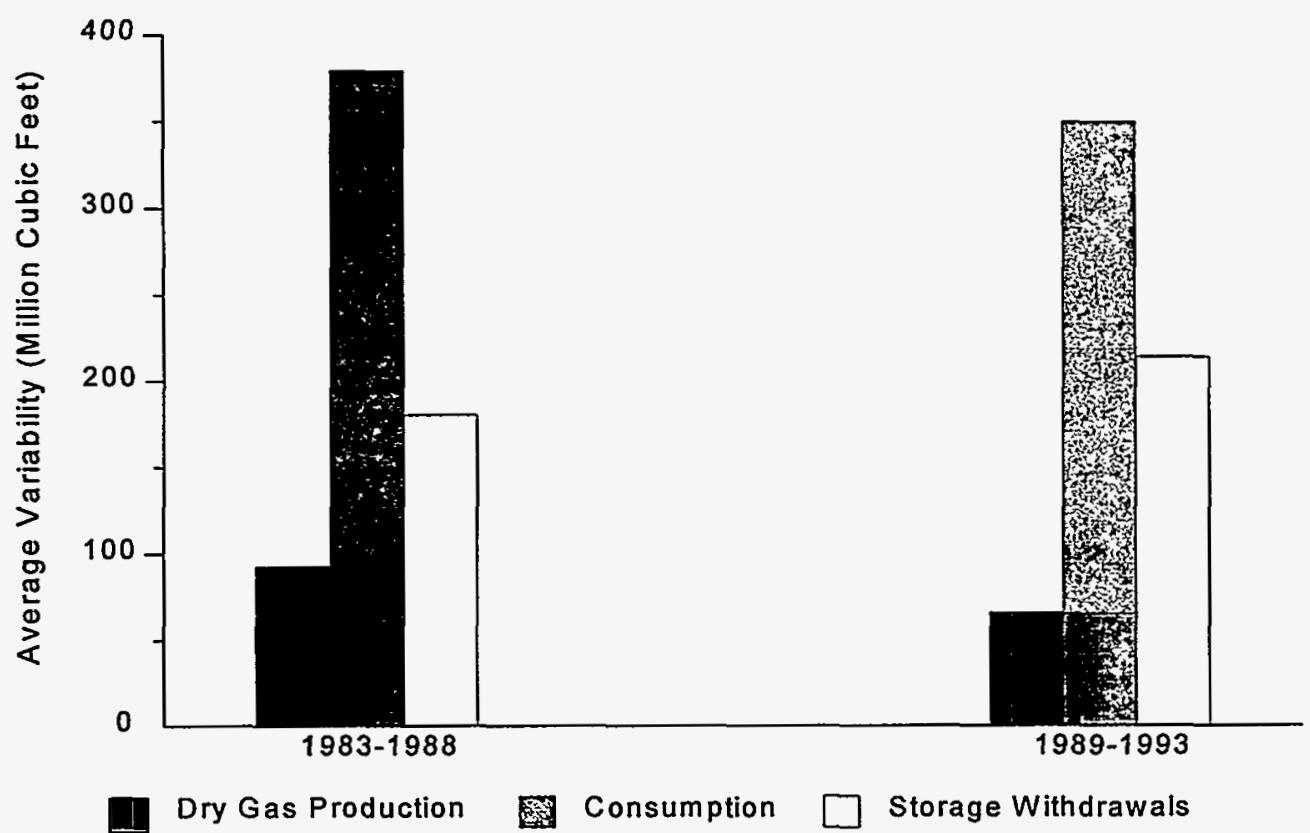

Note: This graph measures the standard deviation of monthly production, consumption, and withdrawals over all months in each time period, 1983-1988 and 1989-1993. The standard deviation measures the average dispersion of an actual production level in a given month from the mean production level over each time period.

Source: Energy Information Administration, Office of Oil and Gas; based on Natural Gas Monthly, historical data series.

Canada and of a more active storage industry (Figure 5). Peak storage withdrawals during the heating season in the late 1980 's and early 1990's have tended to be larger than in earlier years. Imports of gas have also increased throughout the heating season relative to earlier years. What is not apparent from these data, however, is the capability to use storage, especially high-deliverability storage, to satisfy daily and weekly peak demands for gas, which reduces the need to use gas from production sites (see box, p. 4).

The decrease in the variability of production between the mid1980 's and early 1990 's is significant. By 1993 , average monthly variability in production had declined by 48 percent from 1986 levels. The percentage decline in the difference between the peak-month and the low-month production (the range) was also large (Figure 6). The range fell from $322 \mathrm{Bcf}$ to $174 \mathrm{Bcf}-\mathrm{a}$ decline of 46 percent. As a percentage of consumption, domestic dry gas production during the heating season has tended to decline while imports and withdrawals from storage have tended to increase (Figure 7).

\section{Summary}

Storage plays a key role in the natural gas market. The amount of gas in storage is integrated with the performance of every aspect of the gas industry from production at the wellhead to distribution to a household even on the coldest day of the year. The presence of storage facilities in market areas allows monthly production to vary much less than consumption. Moreover, as discussed in more detail in Chapter 3, the contribution of storage to efficiency gains appears to have continued into much of the period of industry restructuring that has taken place since the mid-1980's. This gain in efficiency is indicated by the more intensive use of storage reservoirs and the drawing down of storage stocks. During much of the 1990's, the amount of working gas in storage declined although injection and withdrawal activity increased.

The extensive storage facilities throughout the United States enable the gas industry to charge lower prices for natural gas services than it could without storage because of the gains in efficiency associated with storage use. This is a long-term effect resulting from the huge capital investments made over many years to develop the storage industry. 
Figure 5. Recently, Seasonality in Production Appears to Have Declined as Withdrawals and Imports Have Increased

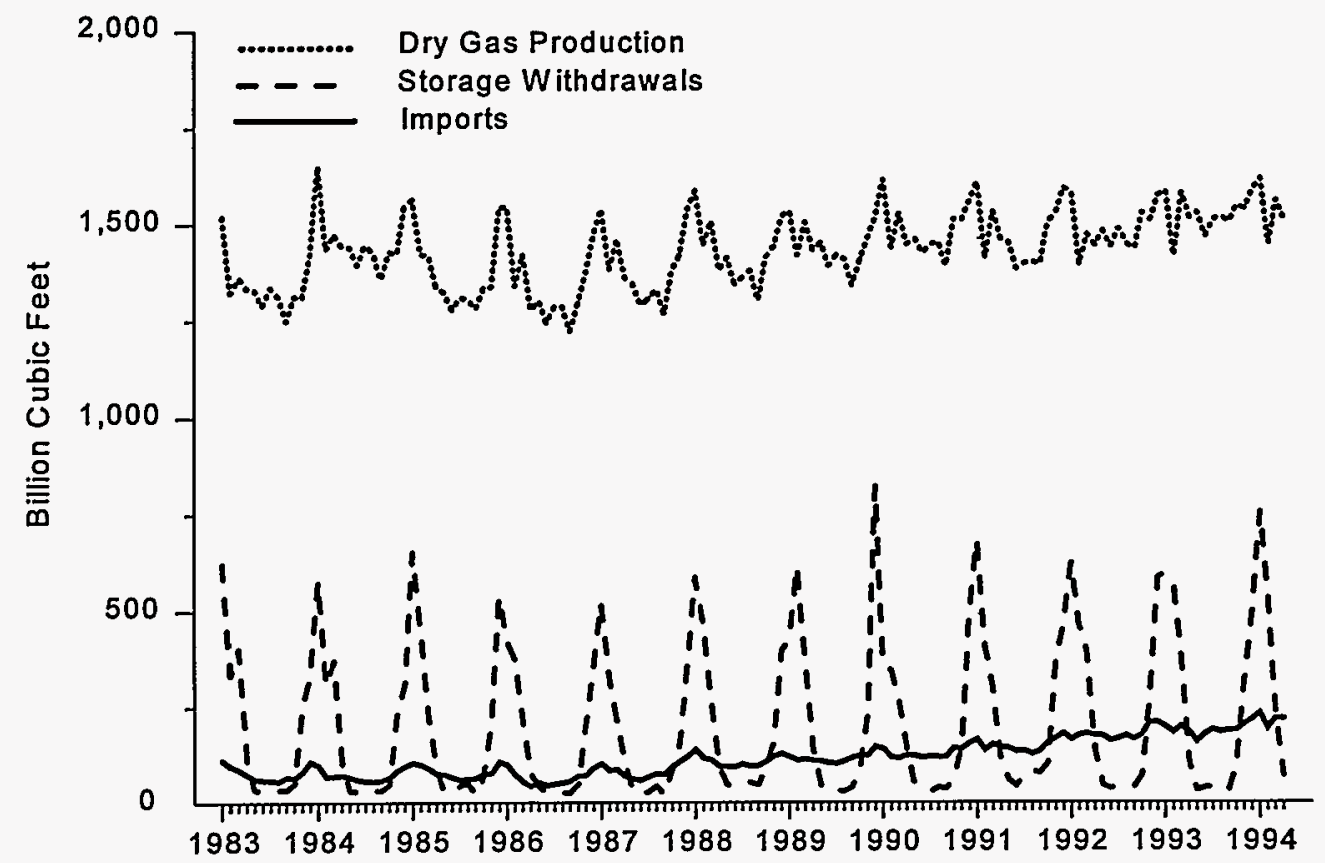

Source: Energy Information Administration, Natural Gas Monthly, historical data series.

Figure 6. By 1993, Average Variability in Production Was About Half of Its 1986 Value

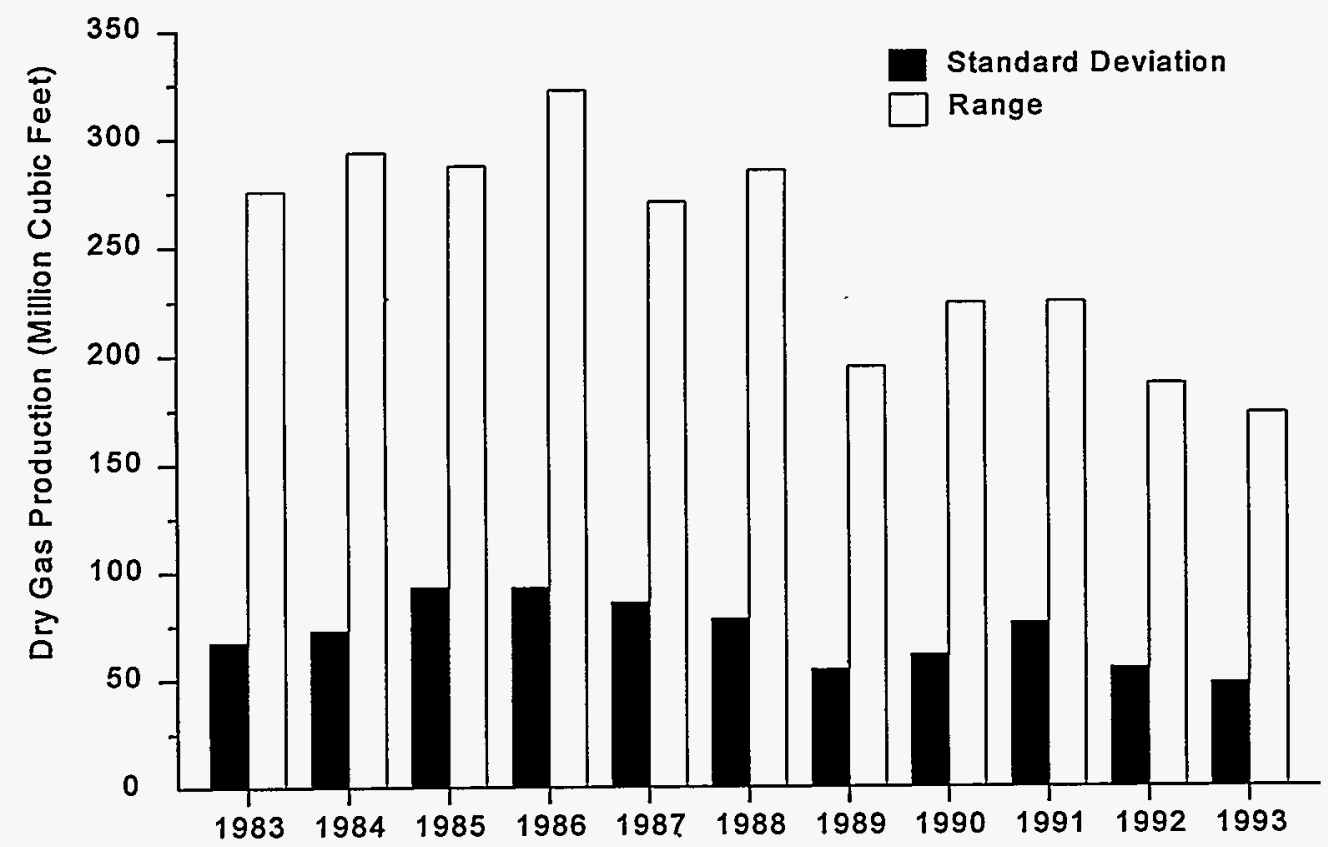

Note: The standard deviation is taken over all months in each year. The range is the difference between the maximum and minimum monthly values in each year.

Source: Energy Information Administration, Office of Oil and Gas; based on Natural Gas Monthly, historical data series. 
Figure 7. During the Heating Seasons in the 1990's, Storage Withdrawals and Imports Have Generally Increased as a Percent of Consumption While Production Has Declined

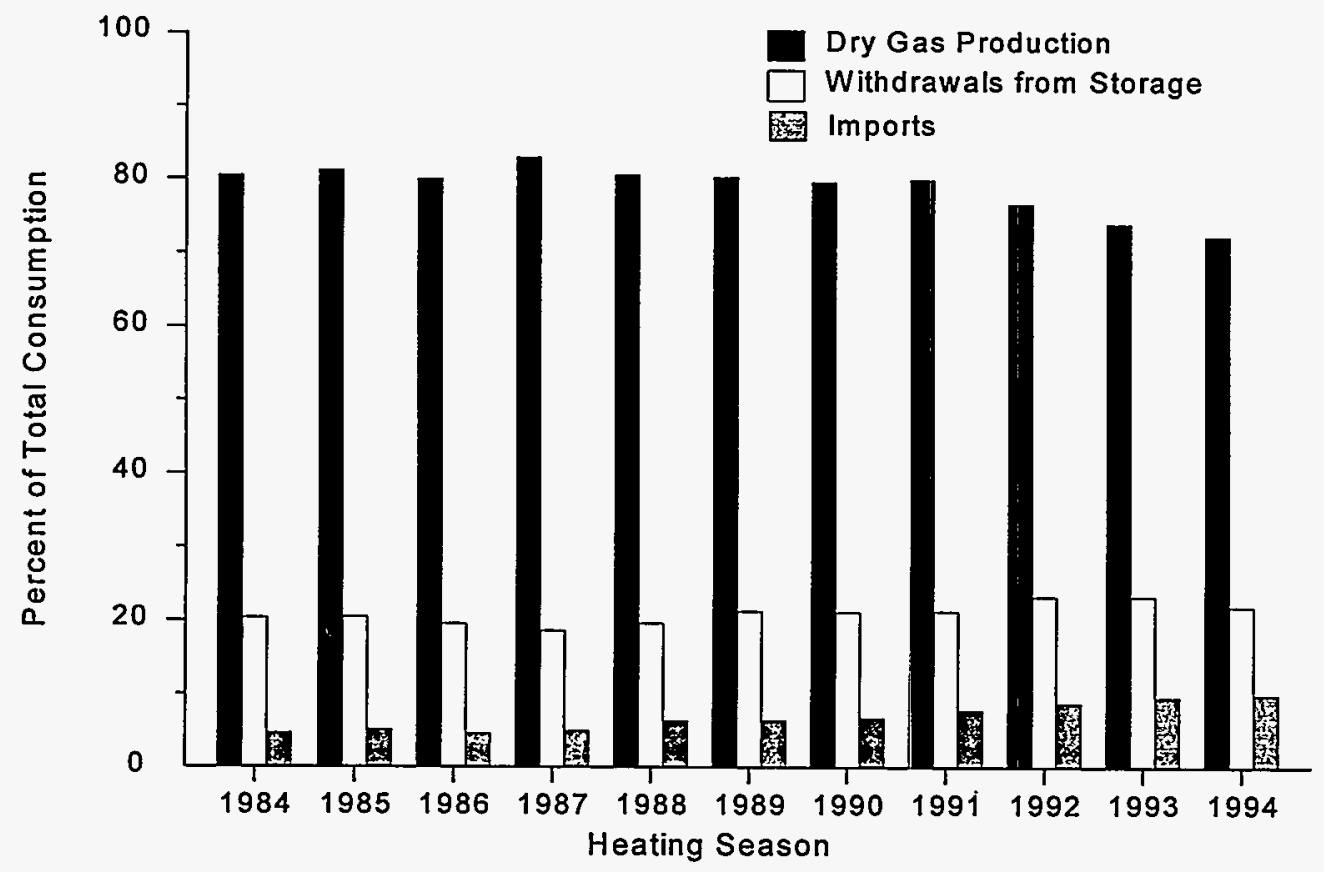

Source: Energy Information Administration, Office of Oil and Gas; based on Natural Gas Monthly, historical data series. 


\section{Relationship Between Natural Gas Prices and Storage Activity}

The ability of the natural gas industry to store large amounts of gas has allowed the production and transmission portions of the industry to operate at a higher level of efficiency than would otherwise be possible. The long-term impact has been to reduce the overall cost of producing and shipping gas, thus reducing the price of gas to end users.

Increasing attention is being paid to using underground storage to exploit short-term changes in natural gas prices to satisfy winter demands at a reduced cost. This management of storage levels in turn has an impact on short-term natural gas prices. Although storage is frequently mentioned in the trade press as a major influence on both spot and futures prices, previous studies have not examined this relationship. The analysis is complicated for several reasons. For example, data are either not generally available or are measured indirectly. Also, the proportion of end-use demand satisfied from storage versus production sites varies greatly throughout the year. In addition, the amounts of gas withdrawn from storage and from production sites are interdependent, particularly during the nonheating season. This interdependence has been expanding and changing in recent years as overall storage activity has increased throughout the year. Thus great care is needed in selecting the means for analyzing the relationship between spot prices and storage activity.

This chapter discusses the short-term relationship between storage levels and price from several different perspectives. Regression analysis techniques are used to gain insight into the strength of the relationships between the different variables examined. ${ }^{12}$ An examination of data on price and the amount of gas in storage at the end of a month relative to expected consumption in the subsequent month reveals a quantitative relationship between prices and storage levels. The chapter also examines daily price behavior to understand the value associated with having gas in storage during periods of high demand. This value increases dramatically as supply conditions tighten during periods of persistently cold weather.

Just as the conditions of December 1989 once served as a benchmark for industry performance, the extremely cold weather and high levels of demand in January and February 1994 will serve as the new benchmark. Temperature and price

\footnotetext{
${ }^{12}$ In all cases, the least-squares regression procedure is used first. Then in several instances, the robust procedure, least absolute deviation, is also used to give less weight to extreme data values. Appendix D provides information, such as regression equation coefficients, for each regression presented in this chapter.
}

data from this period are used frequently in this chapter to examine the relationships between price and storage.

\section{Spot Prices and Monthly Storage Needs}

The factors influencing the relationship between price and storage vary throughout the year. For example, if storage levels are particularly low at the end of March-the end of the heating season-many buyers may decide to purchase large amounts of gas for storage during April, putting upward pressure on spot prices. On the other hand, if at the same time, many new producing wells are brought on line or imports from Canada are larger than expected, then the price of gas may decline instead. Examining monthly data on spot prices and total storage levels over several years shows that the overall relationship between the two series is not readily apparent (Figure 8).

Before 1992, prices tended to be low in the spring and summer and high in the early winter, and storage levels tended to follow a pattern similar to prices. In 1992, prices increased throughout much of the year, yet storage level patterns did not change much from the past. In 1991, prices fell from $\$ 1.32$ per million Btu (MMBtu) in April, the beginning of the nonheating season, to $\$ 1.19$ in July. However, in 1992, prices rose from $\$ 1.57$ per MMBtu in April to $\$ 1.83$ in July. Even though prices rose between April and July in one year and fell in the next, storage levels rose in both years during those months. In 1993 and 1994, the lack of seasonality in prices contrasts sharply with the continuing seasonality in storage levels.

The lack of a clear, direct relationship between movements in storage levels and prices is because the market is more complex than this simple comparison would suggest. Other factors, such as supply availability, expected consumption patterns, movements on the natural gas futures market, and economic conditions, are affecting the prices as well.

Even if other factors that influence price did not change much, the relationship between storage and price would be expected to vary throughout the year. For example, from April through October, storage is being filled in order to reach planned levels by the beginning of the heating season 
Figure 8. Storage Levels and Spot Prices Are Not Clearly Related
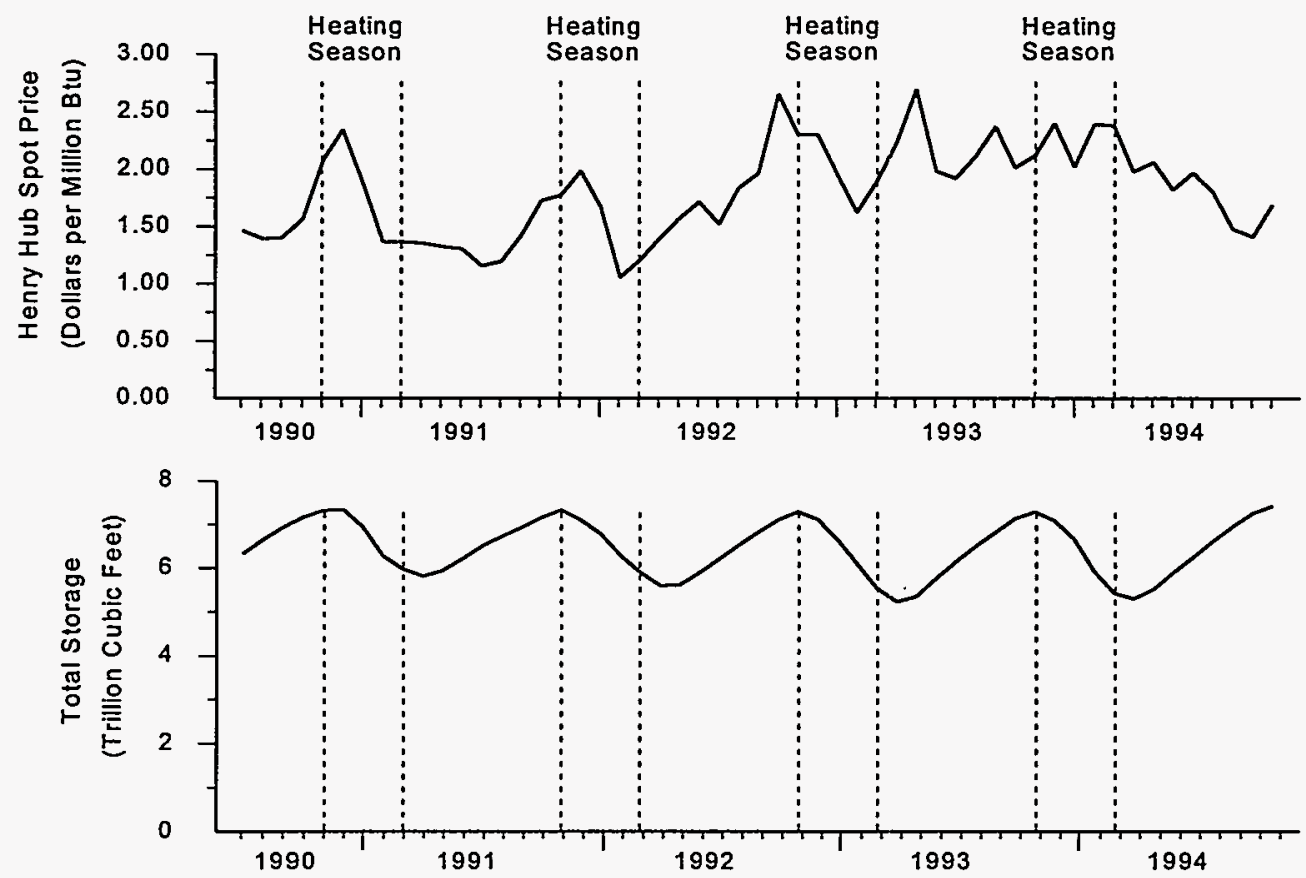

Note: The heating season runs from November of one year through March of the next year. The price data are beginning-of-month prices that apply to deliveries made during the month. The storage data are amounts of gas in storage available at the beginning of the month, but are more typically reported as end-of-month levels. For example, the data shown here for November 1990 are reported in the data sources as the price for (the beginning of) November 1990 and the storage level for (the end of) October 1990.

Sources: Prices: McGraw-Hill, Inc., Inside F.E.R.C.'s Gas Market Report. Storage: Energy Information Administration, Natural Gas Monthly, various issues.

(November 1). Although fill rates are determined by the operational characteristics of each facility, those who want to store gas also have some leeway in determining how much gas to inject each month. They balance their need to have gas in storage by November 1 with the desire to buy gas when they believe it is cheapest during the nonheating season.

The concept of how much gas must be in storage by certain times in the nonheating season has been undergoing a systematic change in recent years. For example, between 1990 and 1993, the percentage of working gas capacity that was filled generally drifted lower. Then during 1994, the percentage increased (see Chapter 3, Figure 19). This changing pattern makes it particularly difficult to determine a simple relationship between spot prices and storage levels from data for the nonheating season.

During the heating season, however, there is much less flexibility in the proportion of capacity that must remain filled because winter weather creates space-heating demands that require sufficient gas to be in storage, ready to meet customer needs. Even during the heating season, however, the influence of storage activity on price is expected to be minor in the months of November and December because stocks of gas are high relative to expected monthly deliveries. ${ }^{13}$ By the end of January though, large amounts of gas have been withdrawn from storage. Because significant deliveries from storage will still be required in subsequent months, storage is likely to be a stronger component of spot price levels during the latter part of the heating season.

\footnotetext{
${ }^{13}$ This may have changed somewhat as a result of Order 636. Contracts now held by many local distribution companies (LDC's) for storage capacity require the LDC to withdraw a certain amount of gas from storage each month. If such withdrawals exceed the needs of the LDC's customers, the gas will likely be sold on the spot market. This may have a depressing influence on price even if it occurs in the months of November or December.
} 
For example, deliverability from storage sites can be expected to decline during this period, in part because of decreased pressure in storage reservoirs. Thus, it is more likely that buyers will have to supplement storage supplies by making purchases on short-term spot (cash) markets in major producing regions. This increases the chance that prices will rise.

The strength of the interaction between storage and price can be estimated by analyzing data that represent storage requirements and spot prices during the latter part of the heating seasons from 1991 through 1994. Storage requirements are represented using the ratio of total gas in storage at the end of January, February, and March, to expected deliveries for the next month. (Expected deliveries are estimated by actual consumption for the month from the previous year.) This ratio indicates the availability of storage gas to meet consumption for the upcoming month, and would be expected to influence the spot price of gas for the next month. Thus, the price series analyzed consists of beginningof-month spot prices for February, March, and April. The spot prices used are those for the Henry Hub. This price series is used widely by the industry as a benchmark and as the price index in longer term indexed contracts. ${ }^{14}$

A greater availability of gas would be expected to put downward pressure on prices, and indeed there is a strong and inverse relationship between the two series (Figure 9) with 59 percent of the variability in price associated with the variability in the storage ratio. Each unit increase in the ratio, that is an additional month's worth of available supply, on average, is associated with a $\$ 1.09$ per MMBtu decline in price.

\section{The Premium Value of Stored Gas in the Short Term}

For some commodities with active futures markets, the futures price is sometimes less than a spot price for current delivery, indicating the value of having gas available for

\footnotetext{
${ }^{14}$ The ratio representing storage requirements consists of total storage at the end of the month (January, February, and March) divided by total consumption expected for the next month (February, March, and April). Expected consumption for a month is actual total consumption for that month in the previous year. The industry frequently uses this as an estimate of expected consumption. Expected consumption based on normal heating degree days could have been used, but this would have captured only spaceheating needs. It would have missed industrial sales that have increased significantly in the past several years largely because of greater gas use by cogenerators. The price data are the average price at the Henry Hub negotiated prior to delivery for each month, based on the beginning-of-themonth price series from Inside F.E.R.C.'s Gas Market Report.
}

immediate delivery rather than at a future time. ${ }^{15}$ Storage provides one option for immediate delivery. Under most circumstances, the difference between the spot and futures prices, called the premium, ${ }^{16}$ is relatively small for natural gas because the industry can anticipate changes in consumption and ensure adequate pipeline supplies. However, under extreme weather conditions when pipeline capacity is fully used, the premium can be substantial. Thus, the value associated with having access to gas in storage is also substantial on those days. The weather patterns of January and February 1994 provide a good example of such extreme conditions (see box, p. 16).

To obtain some indication of the high value of having gas on hand in storage, the difference between the daily spot price at the Henry Hub and the futures price for the expiring contract for January and February 1994 is examined (Figure 10). ${ }^{17}$ The Henry Hub price is used because substantial volumes of gas move through this hub and it is also the delivery point for the futures contract. The analysis shows that even during this period of bitterly cold temperatures, the magnitude of the difference is often small, ${ }^{18}$ and large differences do not persist.

Until January 13, 1994, there was little difference in the two price series. However, on the 13th, when it became clear that a cold front was heading for the major gas consuming regions, spot prices rose. On January 18, the Monday following the weekend the cold front hit, prices on the spot market soared and the difference in the two series was nearly $\$ 0.80$ per MMBtu. Thus, the value of having gas readily available in storage reservoirs increased greatly in a single day.

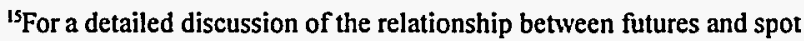
prices, several articles are recommended: Robert S. Pindyck, "Inventories and the short-run dynamics of commodity prices," RAND Journal of Economics, Vol. 25 (Spring 1994), pp. 141-159. Czarnikow Energy, "Backwardation and Contangos in Gas Oil Futures Prices," Petroleum Futures Report (July 1991). Lester G. Telser, "Futures Trading and the Storage of Cotton and Wheat," Journal of Political Economy, Vol. LXVI, 3 (June 1958), pp. 105-128. There are very specific terms for the relationship between futures and spot prices. If the spot price exceeds the futures price, this is known as backwardation. If the spot price is less than the futures price, this is known as contango.

${ }^{16}$ The premium, defined here as the spot price minus the futures price, is an approximation of a measure known as the "convenience yield." The convenience yield is defined as the difference between the spot and futures price after the futures price has been adjusted by subtracting out the cost of storage and the cost of borrowing money. Thus, when the premium is zero, the convenience yield is equal to the cost of money and storage. See Appendix $\mathrm{D}$ for further discussion of these concepts.

${ }^{17}$ The expiring futures contract is frequently referred to as the nearby month contract. It is the contract that is next to expire on the futures market. On the last day of trading for the expiring contract, the daily spot and futures prices should, and for the two series considered here do, differ largely by the difference in the cost of transacting business in the two markets.

${ }^{18}$ Those days on which the premium is small are examples of conditions under which the convenience yield is approximately equal to the cost of storage and borrowing money. See Appendix D for further discussion.
} 


\section{Figure 9. Spot Prices Decline When More Storage Is Available for Deliveries}

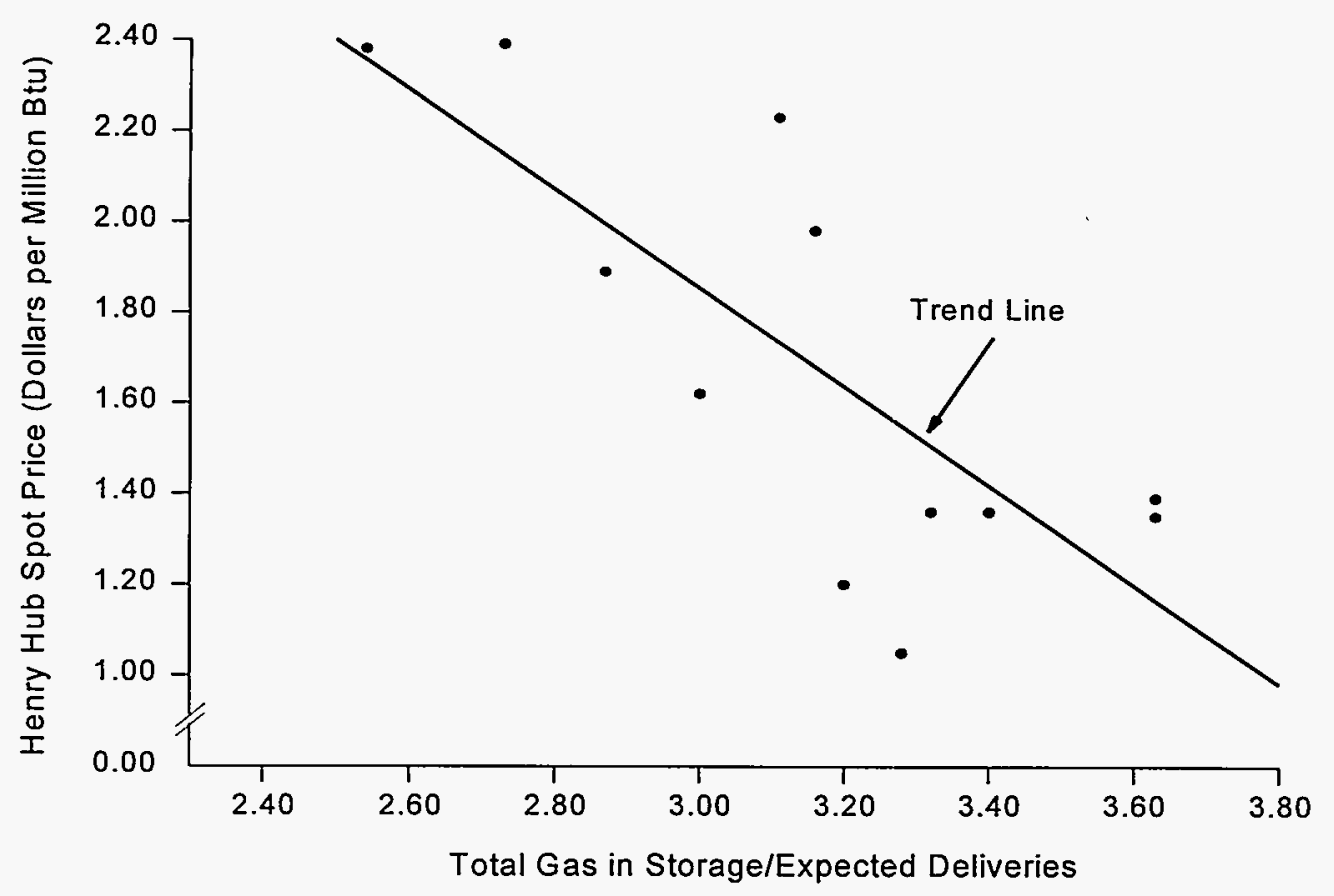

Notes: The ratio of total storage to expected deliveries is end-of-month storage divided by the previous year's total consumption for the next month. Thus, total storage data are end-of-month for January through March, 1991 through 1994, while expected deliveries are consumption for February through April, 1990 through 1993. Spot prices are the average negotiated prior to delivery for the next month and are thus beginning-of-month for February through April, 1991 through 1994. The Trend Line is the result of a least-squares regression.

Sources: Regression Results: Energy Information Administration (EIA), Office of Oil and Gas: derived from: Storage and Expected Deliveries-EIA, Natural Gas Monthly, various issues; and Spot Prices-Inside F.E.R.C.'s Gas Market Report, various issues.

The magnitude of the premium is an indication of the increase in the value of gas at the Henry Hub. However, because a large amount of gas moves through the Henry Hub on a daily basis and because changes in price at other locations tend to be correlated with changes in price at the Henry Hub, the estimated premium is a useful indication of the premium received for stored gas overall and at other locations experiencing similar demands for gas.

After January 22 when warmer weather prevailed, the difference in the two series turned toward zero and negative values. However, when another blast of frigid temperatures was forecasted, spot prices rose significantly, and the premium peaked at $\$ 1.12$ per MMBtu on February 2. Thereafter, the premium was not much different from zero during most days through April 23, and as expected was negative when the temperature returned to near normal levels.
During periods of stress caused by sudden declines in temperature, the premium can be expected to rise. In fact, profits approximating the premium could be obtained by owners of stored gas who do not need the gas for their own current needs. Such a circumstance may be unusual, but if owners find buyers with sufficient pipeline capacity they could sell the gas from storage at the prevailing spot price nearest their storage location. That price could be above or below the average price for the day reported at the Henry Hub. Owners could then replace the gas sold with gas purchased under a futures contract at the lower futures price. ${ }^{19}$ If a sufficient volume of gas were traded in this manner, it would have the effect of lowering spot prices and raising futures prices, moving the two series into closer balance. 
Figure 10. Prices Reacted to the Frigid Weather in January and February 1994
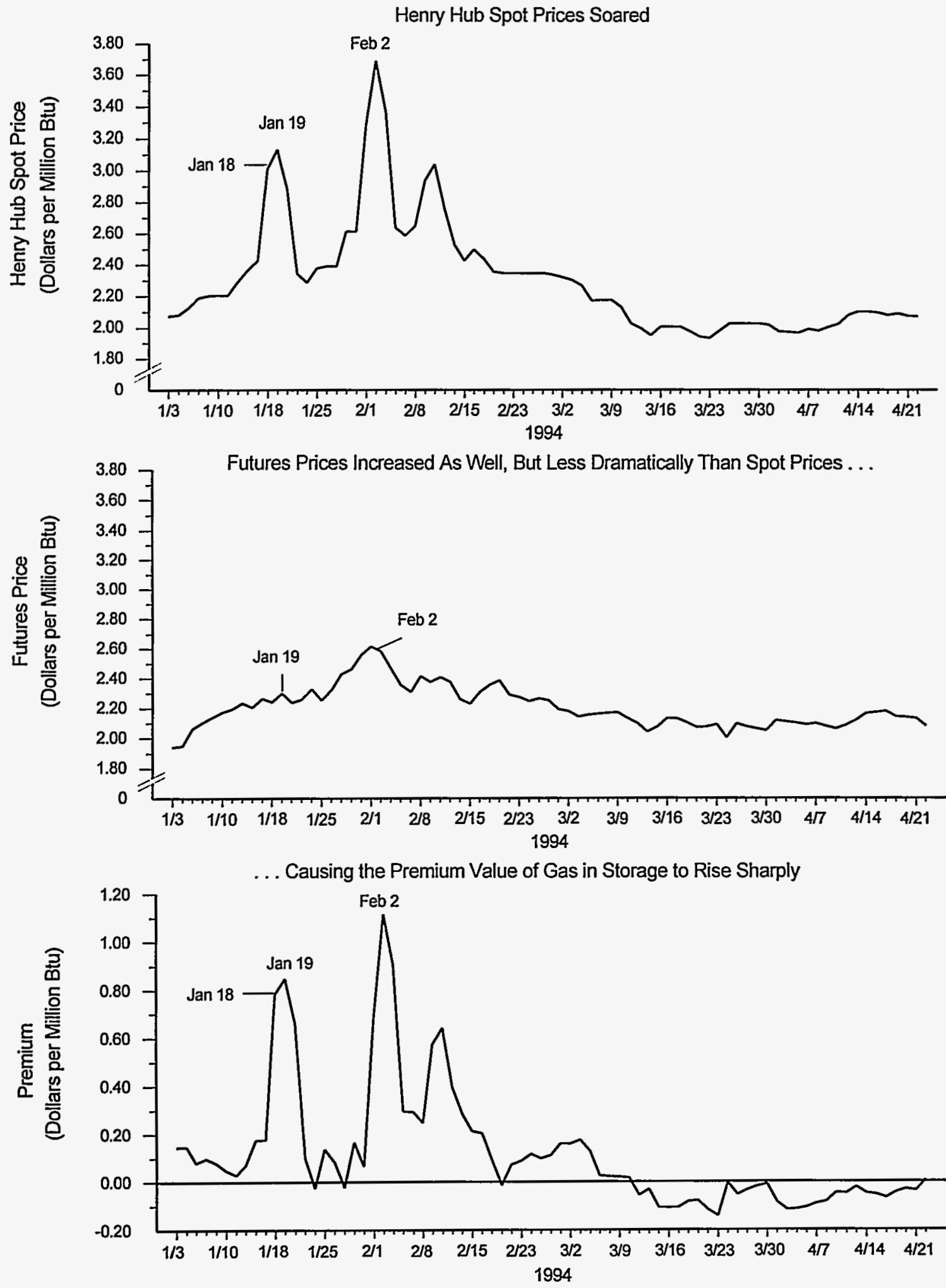

Notes: Futures prices are for the expiring contract. The premium is the difference between the spot price and the futures price. Data are unavailable for weekends and holidays. Because vertical scales differ, graphs should not be directly compared.

Sources: Henry Hub Spot Price: Pasha Publications Inc., Gas Daily. Futures Price: Commodity Futures Trading Commission, Division of Economic Analysis. Premium: Energy Information Administration, Office of Oil and Gas: derived from: Henry Hub Spot Price and Futures Price. 


\section{Weather Patterns Strongly Affect Storage Use}

Natural gas consumption is influenced more by weather patterns than is almost any other commodity. The gas industry makes its plans for the heating season based on expectations of normal winter temperatures and common deviations from normal. However, the flexibility of the system and the location of storage sites enable the industry to adjust as needed when prolonged periods occur with temperatures far below normal.

The natural gas industry was tested by the cold weather of January 1994. The severity of the cold spell, which produced record-setting demand for natural gas, can be seen by examining the average of temperatures during the period for a selection of cities (Figure 11). The cities-Kansas City, Missouri; Chicago; Pittsburgh; and New York City-were selected as representative of large gas markets in the areas hit by the cold.

Tracking of the weather pattern during the coldest days (Figure 12) is useful for illustrating certain important aspects of the gas industry. The gas system in the United States, especially in the producing regions and the region near the Great Lakes, is highly interconnected. Thus, during the heating season, when the weather becomes colder in one area and warmer in another, gas can be moved to the end users that need it the most.

This flexibility is supported by the location of natural gas storage facilities. If one overlaid a weather map for these days with a storage map, one would find that a large percentage of the U.S. storage facilities are located in market areas where the weather can turn cold rapidly. Many of these storage facilities are former producing oil and gas reservoirs, left over from a once thriving producing region that ran from Illinois to Pennsylvania. The placement of these storage reservoirs was determined not only by geology but also by gas demands, as many gas consumers now live in areas that can be served by storage in this region.

\section{Figure 11. Average of Temperatures for Four Cities Plumınets in Mid-January}

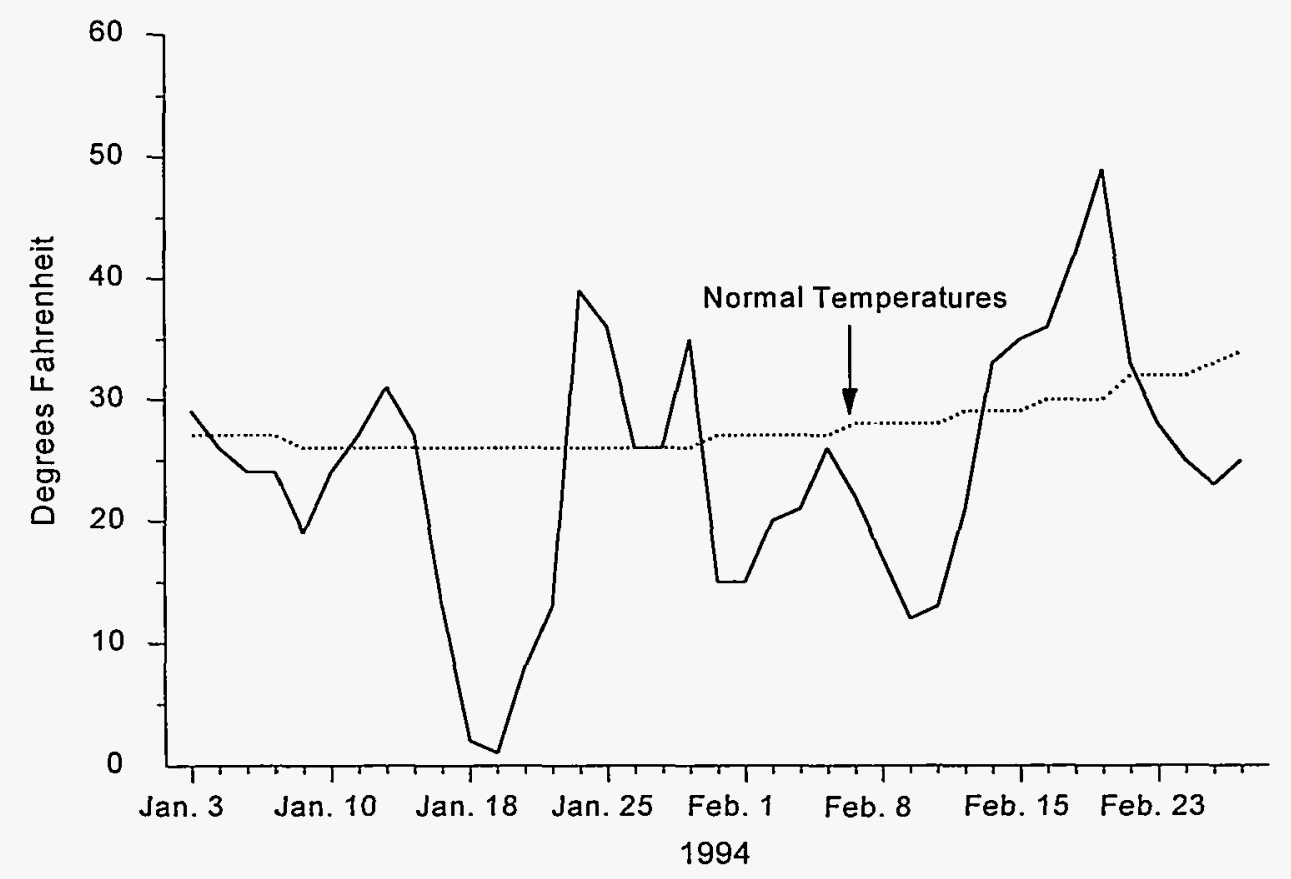

Note: Data are the mean of average daily temperatures in Kansas City, MO; Chicago, IL; Pittsburgh, PA; and New York, NY. Data were excluded for weekends and holidays.

Source: Energy Information Administration, Office of Oil and Gas: derived from: National Oceanic and Atmospheric Administration, National Climatic Data Center. 


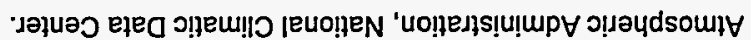

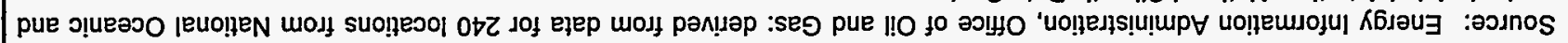

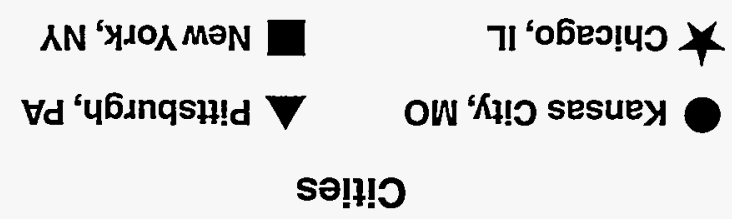

ןeudoN Moleg 6b-0t

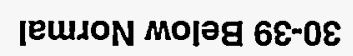

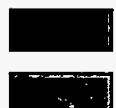

ןew.JoN Mo|əg 6L-0!

ןEudoN Mojəg 6Z-0Z

ןEuJoN Mojəg 6-1

[EULON әnоq $\forall$ 6-0

รәәнбәа ң!әчนәдие

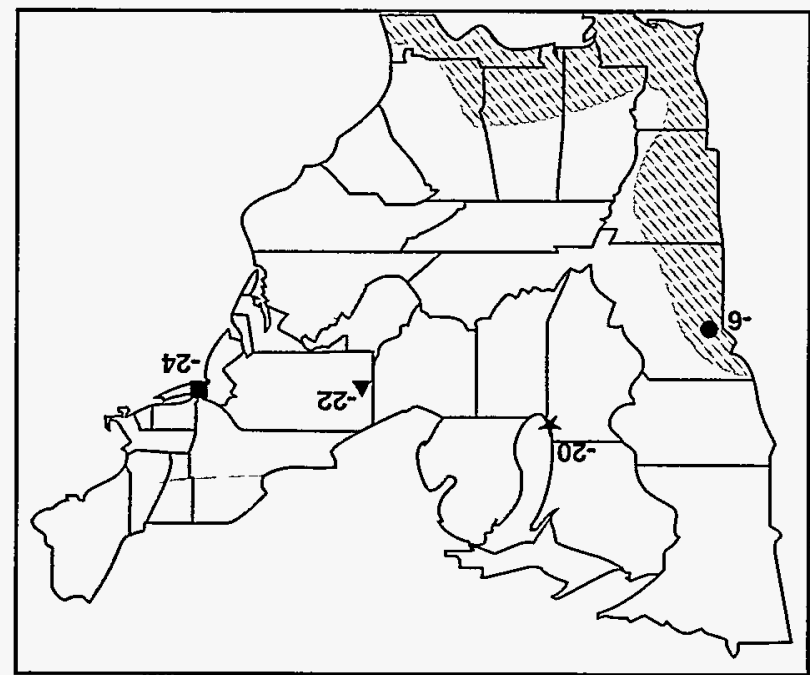

0Z Kienuer

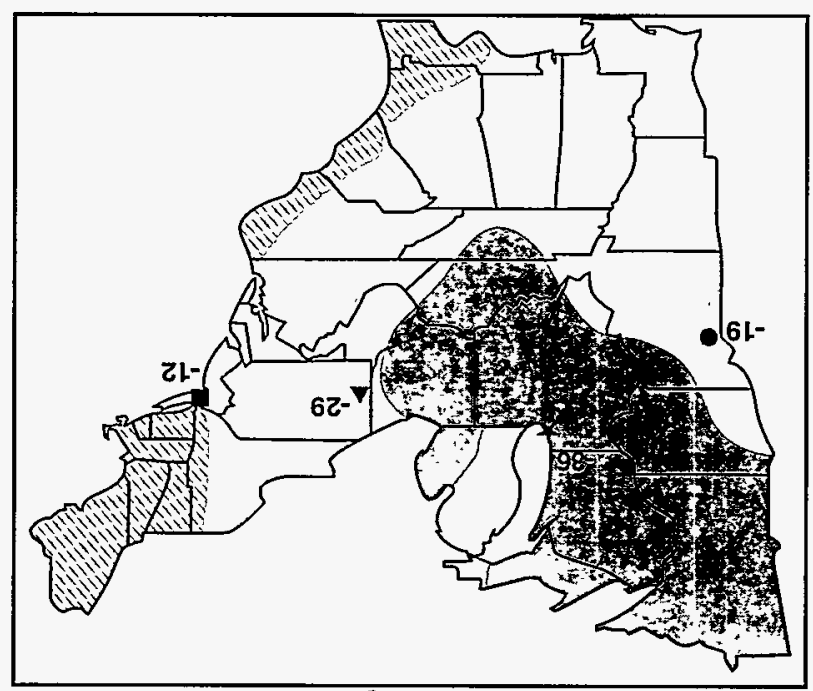

81 Kdenuer

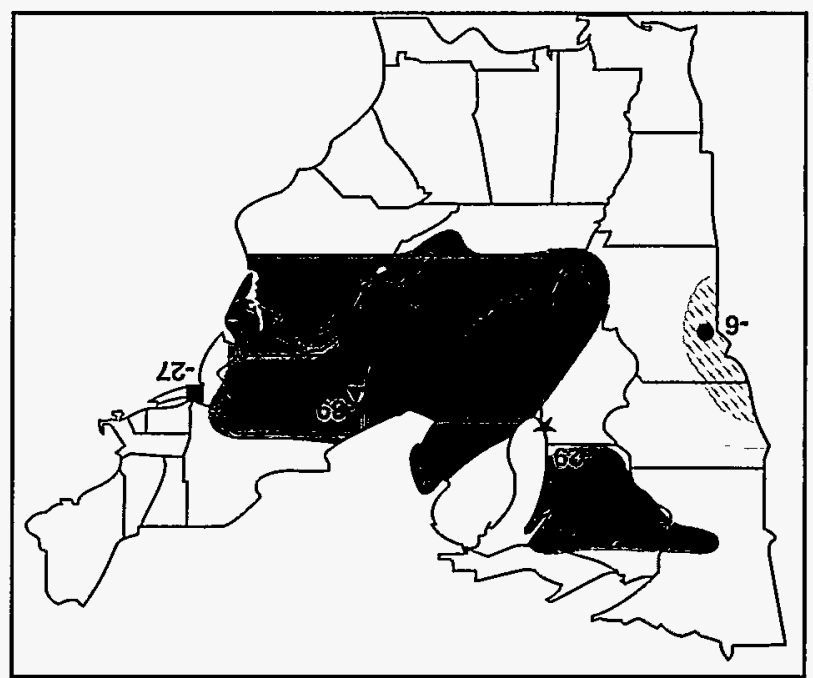

6. KJenuer

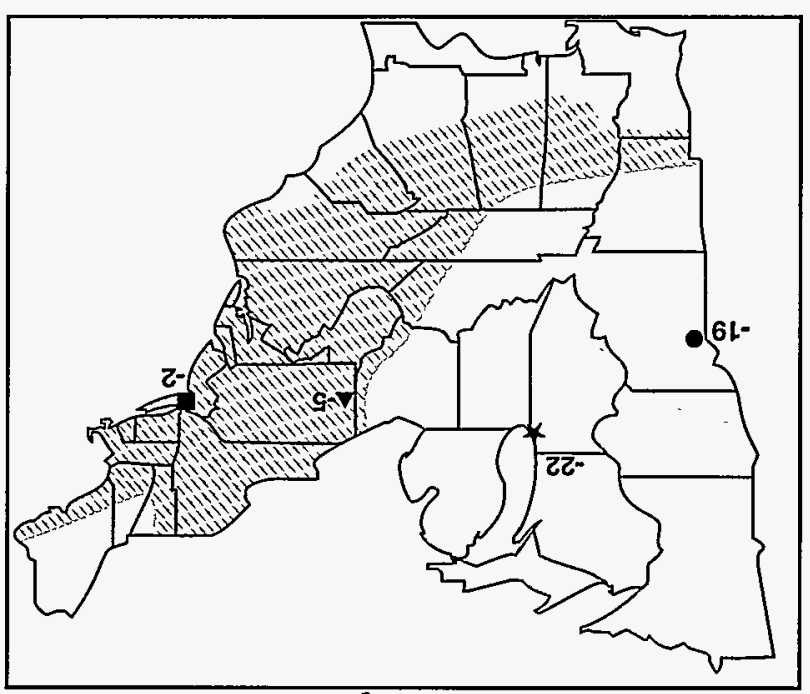

LL KJenuer

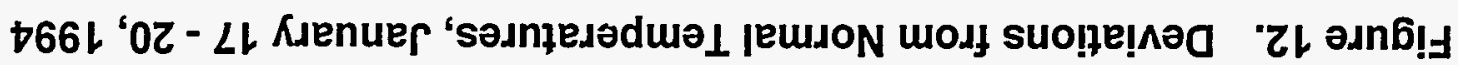




\section{The Premium and Temperature Deviations}

Given the importance placed on having storage supplies when conditions are extreme, one would expect the premium to move in the same direction as storage withdrawals; ${ }^{20}$ that is, a higher level of withdrawals would imply a larger premium. Information on the premium and daily storage withdrawals is needed to analyze this relationship. While the daily premium can be calculated, daily measures of storage withdrawals are not available. However, because gas from storage is needed most during periods of cold weather, daily deviations from normal temperature can serve to represent daily storage withdrawals. Thus the relationship between the premium and temperature deviations is analyzed instead. (See Appendix D for a detailed discussion.)

A direct relationship exists when the two data series are analyzed for January 3 through February 28, 1994. The deviation from normal temperatures explains 37 percent of the variability in the premium during this period (Figure 13). Each unit increase in the deviation from normal temperature is associated on average with an increase in the premium of $\$ 0.018$ per MMBtu.

The explanatory strength of the relationship is weakened because the observations for February 2 and 3 are outliers with respect to the other data points. ${ }^{21}$ When less weight is assigned to the outliers, 51 percent of the variability in the premium is explained by the deviations from normal temperature. ${ }^{22}$

The magnitude of the premium on these days, for example $\$ 1.12$ per MMBtu on February 2, represents, in part, the perceptions of the industry and uncertainty about the overall capability of the gas system to deliver gas as needed. While such perceptions cannot be measured directly, they can have a major impact on price (see Appendix D).

\footnotetext{
${ }^{20}$ For a theoretical discussion of this issue, see Michael J. Brennan, "The Supply of Storage," American Economic Review, 48 (1958), pp. 50-72.

${ }^{21}$ These two observations for early February were identified as outliers by using the ratio of the residual (the difference between the line and the observed value), relative to the standard error of the residual. The ratio was greater than 3 in both instances. See Appendix D for further discussion.

${ }^{22}$ When additional variables are introduced, the explanatory power of the regression increases. For example, if less weight is assigned to the outliers (least absolute deviation) and a proxy variable is added to capture the cost of storage and the cost of borrowing money, 69 percent of the variability in the premium can be explained. Alternatively, if the same proxy variable is used and a third variable is added to estimate the increase in the premium that is due to uncertainty in the gas industry in early February, then 76 percent of the variability in the premium can be explained. See Appendix D for more details.
}

\section{Spot Prices and a Storage Load Indicator}

Another way of looking at the relationship between storage and price is to examine the effect of prolonged demand (load) for gas from storage facilities. During the later part of the heating season, the operational conditions at storage sites can be quite different than at the beginning of the heating season. For example, with lower storage levels and reservoir pressure, the sustainable deliverability from a reservoir may be significantly less than at the beginning of the season. One way of examining this effect on prices is to look at cumulative daily deviations from normal temperature.

Cumulative temperature deviations can serve as an indicator of cumulative daily storage withdrawals, and thus reflect the overall load placed on the storage industry during persistently cold weather. Cumulative deviations from normal temperature are similar to the heating degree day (HDD) index, which is used widely throughout the gas industry to plan and schedule deliveries of gas. But they are also different because the HDD index is a sum of average daily deviations from some base temperature, usually $65^{\circ} \mathrm{F}$, and deviations above $65^{\circ} \mathrm{F}$ are excluded from the calculation. Whereas an HDD index is used to obtain an indication of the influence of temperature on space-heating requirements, the sum of average deviations from normal temperature, referred to here as a "cold weather index," is used to obtain an indication of the influence over time of temperature on storage requirements or load.

The weather of January and February 1994 again provides some insights into this relationship. The cold weather index (storage load indicator) reveals an interesting pattern (Figure 14). It rises rapidly in the third week of January, subsides slightly, then rises consistently once more at the beginning of February. The initial spike in the spot price at the Henry Hub (Figure 10, top graph) corresponds well to the cold weather index when the coldest temperatures were experienced in mid-January. After falling, the spot price remained relatively constant between January 25 and 27, when the index hardly changed. Then in spite of an increase in temperature on Friday, January 28, the spot price rose as weather was predicted to turn cold again over the weekend. The price then rose sharply on February 1 and 2, at a faster rate than would be expected from the mid-January patterns of the spot price and the cold weather index. (The impact of the weather on other wellhead markets is described in the box on page 20.) 
Figure 13. The Premium Value of Gas Increases as Weather Becomes Colder

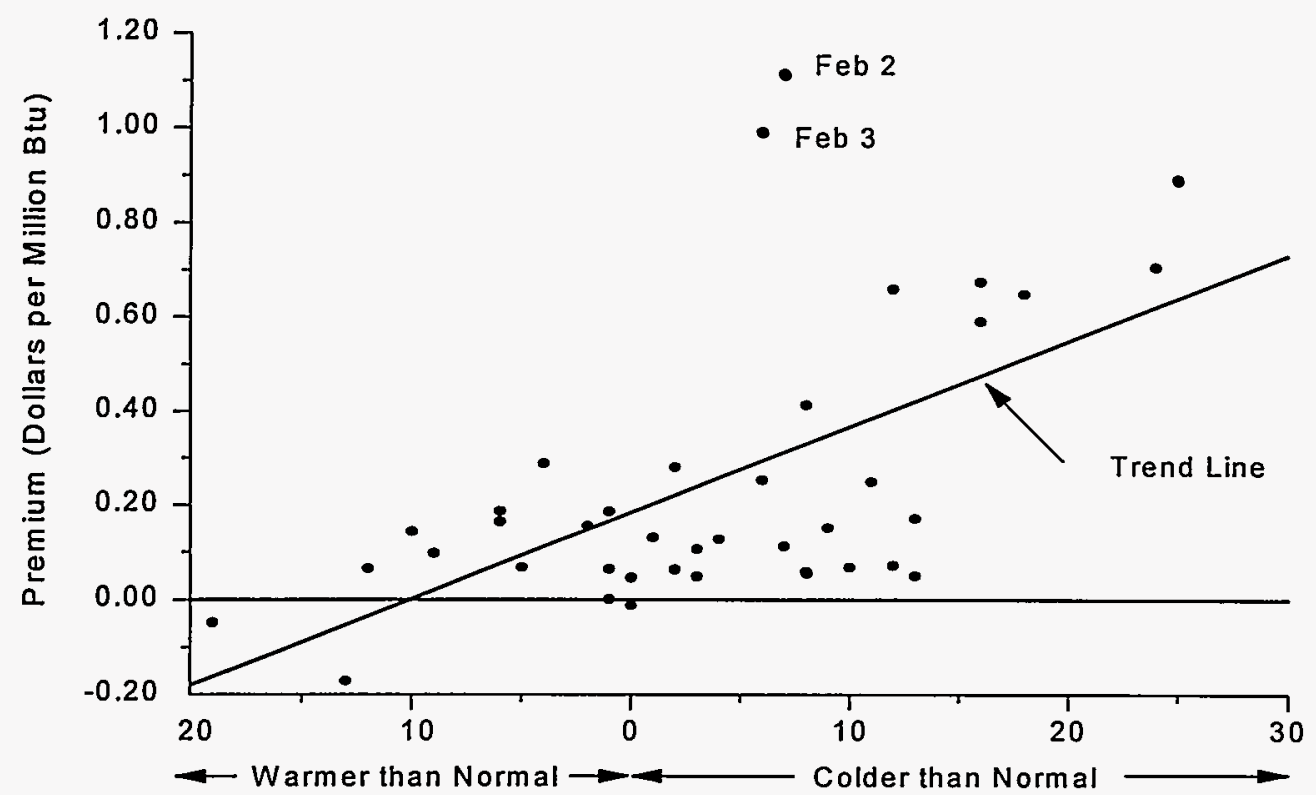

Temperature Deviation (Fahrenheit Degrees)

Notes: The premium is the difference between the Henry Hub spot price and the futures price for the expiring contract. The Trend Line is the result of a least-squares regression. Data are for January 3 through February 28, 1994, excluding weekends and holidays.

Sources: Regression Results: Energy Information Administration (EIA), Office of Oil and Gas: derived from: Premium-derived from Spot Prices: Pasha Publications Inc., Gas Daily, and Futures Prices: Commodity Futures Trading Commission, Division for Economic Analysis; and Temperature Deviation-derived from temperature data from National Oceanic and Atmospheric Administration, National Climatic Data Center. (See Appendix D.)

Figure 14. Cold Weather Index Shows Persistence of Severe Temperatures

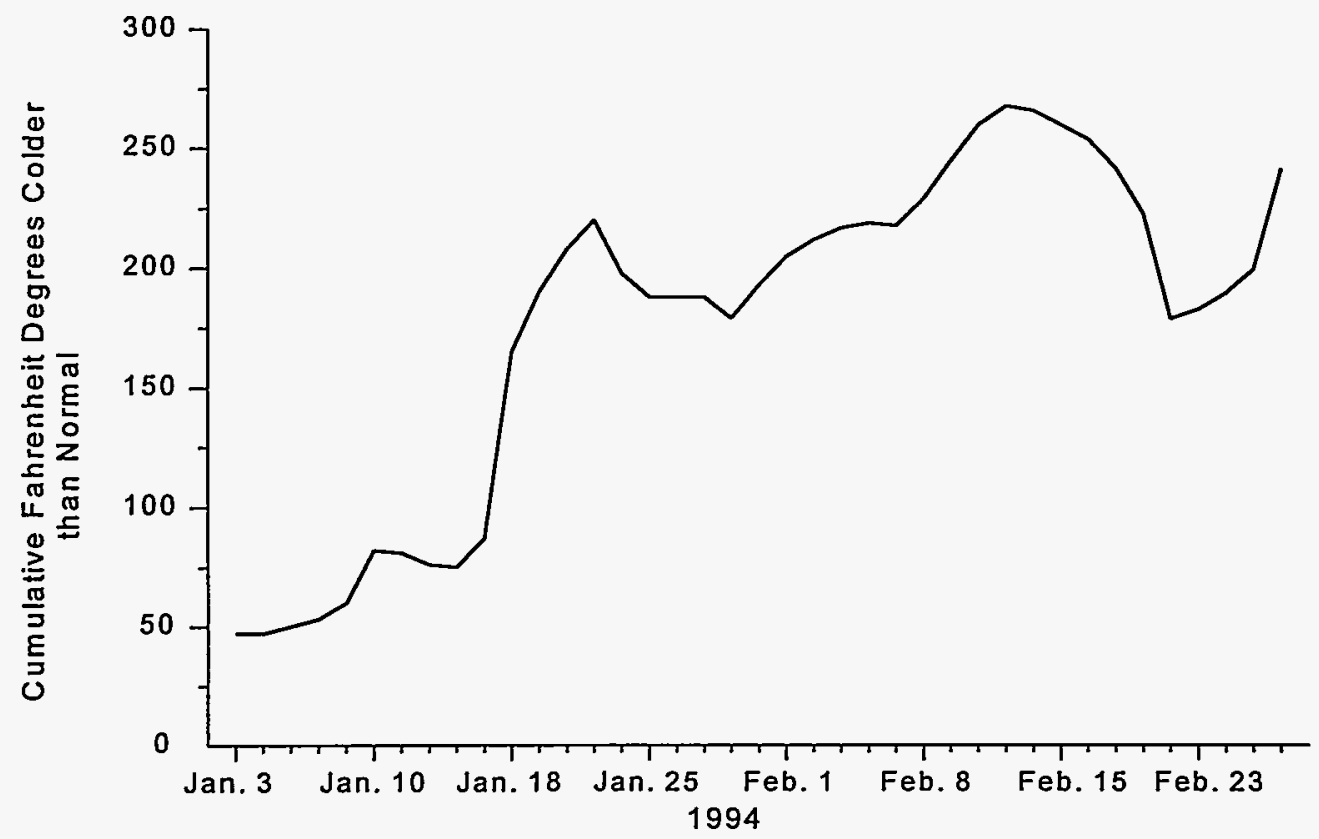

Note: The cold weather index is the cumulative of the average deviation from normal temperatures for four cities: Kansas City, MO; Chicago, IL; Pittsburgh, PA; and New York, NY. The data were accumulated beginning in mid-December when temperatures first began a systematic decline from normal levels. Data for weekends and holidays were included in the calculation but excluded from the graph.

Source: Energy Information Administration, Office of Oil and Gas; derived from temperature data from National Oceanic and Atmospheric Administration, National Climatic Data Center. 


\section{Regional Spot Prices Reacted Differently to Cold Spell}

The price of natural gas increased dramatically in much of the United States during the January 1994 cold spell. Spot prices changed significantly at locations serving major storage markets and northern and eastern end-use markets, and modestly or not at all at locations serving western markets and minor storage markets. This section looks at spot price behavior at several different locations from January 14 through 25 (Figure 15).

- The Henry Hub is a major transfer point that handles large volumes of gas on a daily basis. So many buyers and sellers engage in gas transactions at this point that the Henry Hub was chosen as the delivery point for natural gas futures contracts. Gas from this hub serves many end-use and storage markets, yet there is little storage nearby. The spot price exhibited greater variability at the Henry Hub than at most other major transfer points for natural gas in the United States. This greater variability was most probably a consequence of the accessibility of the Henry Hub to the major markets experiencing large shifts in demand. Other factors include the large number of exchanges of different sizes that take place at the hub on a regular basis and the lack of nearby storage sites to augment supply from production sites. Because of the large volumes of gas that pass through the Henry Hub and the attention that price at the Henry Hub receives within the industry, reported prices probably better measure the full range of transactions that take place at this hub than at many other major exchange points for natural gas. Prices varied by more than $\$ 1.00$ per million Btu (MMBtu) during the period considered. For example, leading up to the most severe part of the cold spell, the Henry Hub spot price rose from a low of $\$ 2.35$ per MMBtu on Friday, the 14th of January, to $\$ 3.25$ per MMBtu on Wednesday, the 19th of January. On the 19th alone, prices varied by $\$ 0.21$ per MMBtu.

- The variability in price between days was also great at a location on the Iroquois pipeline system near the U.S./Canada border at Niagara Falls. This system serves the New England market where storage is scarce or nonexistent. Price variation was strikingly comparable to the Henry Hub prices, varying from a low of $\$ 2.35$ per MMBtu on the 18 th of January to a high of $\$ 3.25$ on the 19 th. After the 20 th, prices plummeted and stayed constant between days much as they had prior to the 19th.

- Texas Eastern Transmission Corporation's (TETCO's) Katy Hub, like the Henry Hub, is near a major producing region. Located near Houston, the Katy Hub is a major transfer point for gas in east Texas, the heart of the gas industry, and was a prime candidate for deliveries through the futures contract. Several major storage sites, including numerous salt dome sites, are located in east Texas, effectively increasing the supply of gas available from this area. This may help explain the relative lack of price variability at the Katy Hub during the cold spell. It is also consistent with other statistics of increased injections into storage and increased industrial consumption during February in Texas, which suggest that supplies were more than adequate in Texas at the end of January.

- The Panhandle Eastern Pipeline Company (PEPL) interconnect, in the panhandle of Oklahoma, exhibited similar price variability to that of the Katy Hub. This suggests that both locations experienced similar supply and demand conditions during the time period.

- The Appalachian locations on the Columbia Gas Transmission system are mostly in Pennsylvania, Ohio, and West Virginia. There are major space-heating markets for natural gas near these points, which are supported by nearby storage facilities. The many storage sites may explain, in part, the relatively modest increase in price during the cold weather.

- The San Juan and Permian locations, which primarily serve western markets, in particular California, were not experiencing cold weather during the period. Hence, spot prices remained relatively constant at these locations.

- Only the Northwest interchange experienced less price variability than the San Juan and Permian locations. This lack of variability is explained by the fact that this interchange serves the west coast market exclusively.

During the time period, prices varied between days as the changing conditions brought on by the cold weather manifested themselves. Prices increased as the weather became colder, but they soon returned to previous levels once the most severe weather had passed. 
Figure 15. Henry Hub and Iroquois Have Largest Increase in Spot Prices, January 13-24, 1994
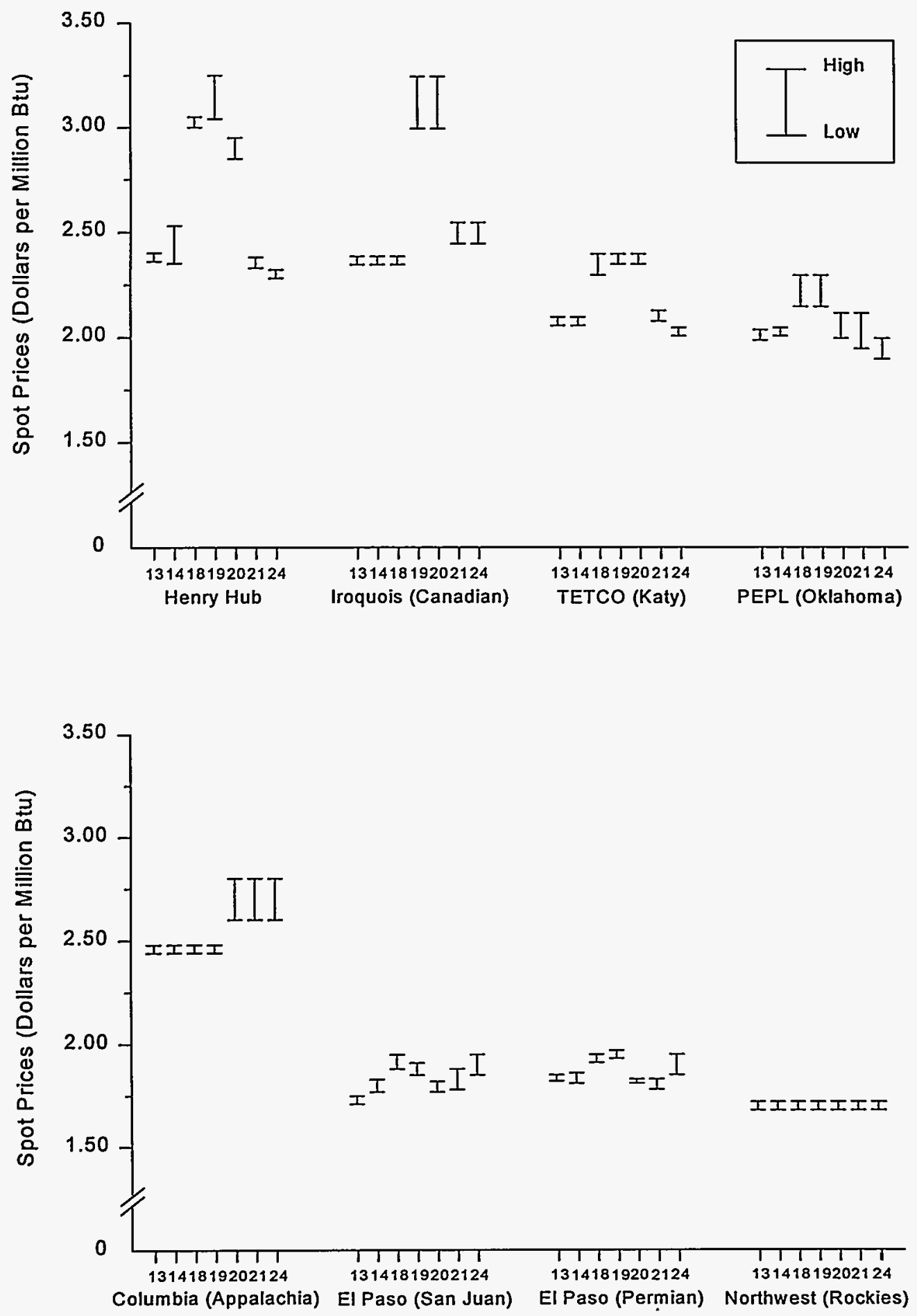

TETCO $=$ Texas Eastern Transmission Corporation. PEPL $=$ Panhandle Eastern Pipeline Company.

Note: Data are not available for weekends and holidays.

Source: Pasha Publications Inc., Gas Daily. 
This movement in the spot price indicates that other forces were at work in driving up prices in early February. The response probably resulted from a combination of factors. The industry had passed through the severe cold of mid-January, and then experienced another dip in temperatures at the end of the month. Then, even though temperatures were rising in early February, another blast of cold weather was forecasted. Storage had been used extensively during January, pipeline capacity was tight, and spot prices had been volatile during January's bid week, leaving traders wondering what was going to happen next. ${ }^{23}$

Price movements on the futures market also may have influenced the spot price in early February. Futures settlement prices had been rising consistently since January 25 , from $\$ 2.25$ to $\$ 2.64$ per MMBtu on February 1 . Thus the increase in price on the spot market, in part, could have been a lagged response to changing expectations as represented by prices on the futures market. Futures prices then fell precipitously by $\$ 0.20$ per MMBtu on February 3, which was followed by a large drop in price on the spot market on February 4.

An analysis of the two data series shows an overall, positive relationship between the spot price and the cold weather index, that is, price increases when the index increases (Figure 16). However, the index explains only 26 percent of the variability in the spot price. This low percentage is due to the inability of the index to explain the three very high prices at the beginning of February. ${ }^{24}$ When these extreme values are given less weight, the index explains 41 percent of the variability. Each 100-unit increase in the index is associated with a $\$ 0.27$ per MMBtu increase in the spot price under the first analysis, and with a $\$ 0.22$ per MMBtu increase when the outliers are given less weight.

\section{Summary}

The factors influencing the relationship between price and storage vary throughout the year as the immediacy of the need for supplies from storage changes between the heating and nonheating season. During the heating season, however, there is a strong relationship between storage and movement in spot prices.

- During the latter part of the heating season, the ratio of storage levels and expected requirements for the next month is strongly related to changes in spot prices. When the amount of gas in storage relative to expected deliveries rises by one unit (e.g., from a ratio of three to four), spot prices during the following month can be as much as $\$ 1.09$ per MMBtu lower as a result.

- There is a large premium associated with having ready supplies of gas in storage when very cold weather occurs. During the extreme weather conditions experienced in January 1994, the value of having supplies from storage readily available was as high as $\$ 1.12$ per MMBtu.

In the short term, the relationship between storage levels and expected deliveries during the heating season is important in explaining changes in prices on the spot market. Over the longer term, there are other significant factors that influence the operation of the industry and pricing of storage services as well. The next chapter discusses some of the ways the industry has responded to FERC Order 636 and other institutional changes. One particular example has been the increased development of storage in gas producing areas. This should enhance the reliability and flexibility of the gas industry because much of the new storage is salt dome storage. This increased flexibility should further reduce the seasonality of wellhead prices and also reduce the persistence of high premium prices for gas when extraordinarily cold weather hits.

\footnotetext{
23"February Pricing Picture Confused By Late January's Dizzying Heights" and "Special Report: If You Thought Mid-January's WeatherDriven Market Was Intense...," Inside F.E.R.C.'s Gas Market Report, January 28, 1994, p. 1, and February 2, 1994, pp. 1, 9-10, respectively.

${ }^{24}$ The observations for February 1, 2, and 3 were identified as outliers by using the ratio of the residual (the difference between the line and the observed value), relative to the standard error of the residual. The ratio was 2.2 or greater in all three instances.
} 


\section{Figure 16. Daily Spot Prices Rise as Cold Weather Index Increases}

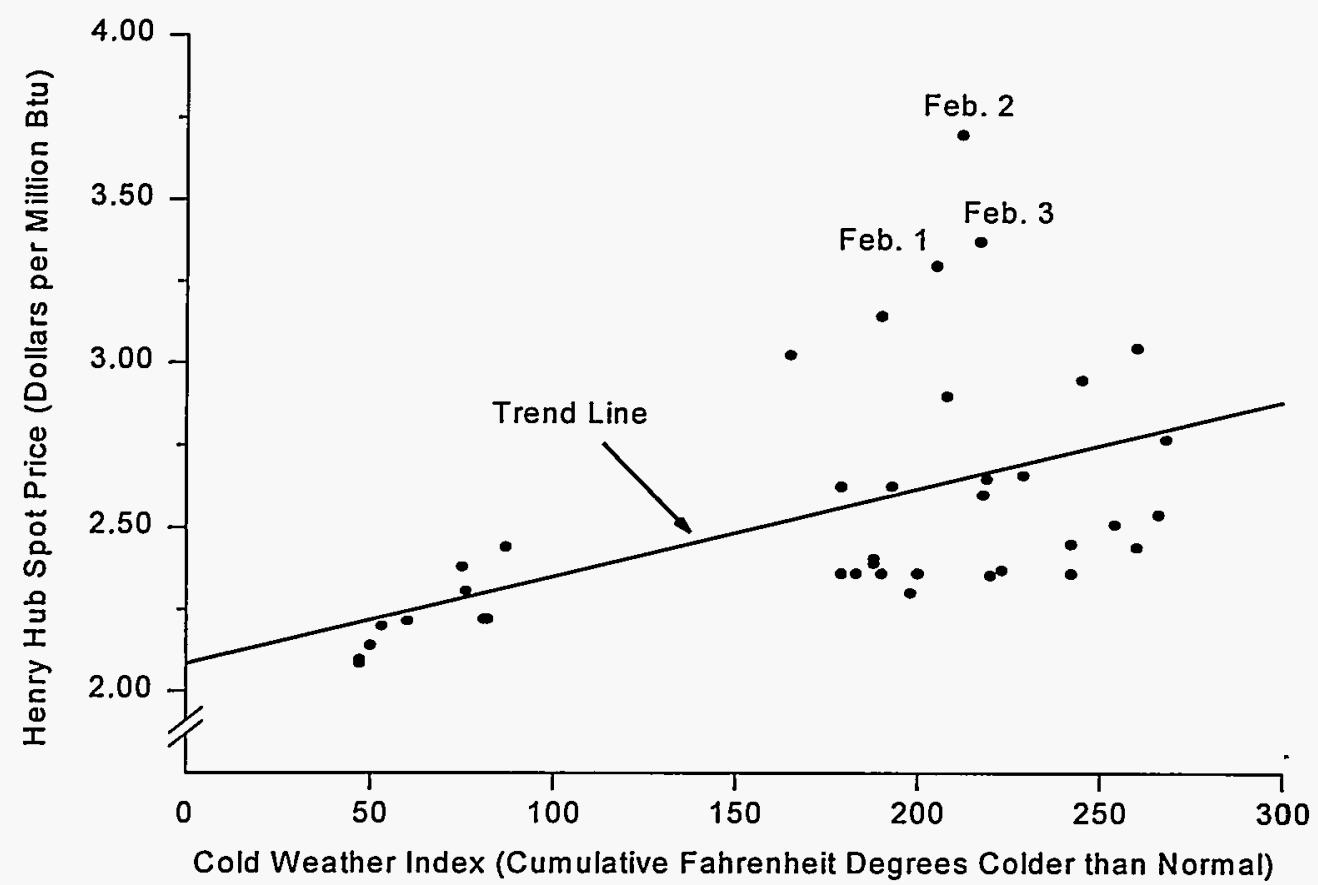

Note: The Trend Line is the result of a least-squares regression. Data are for January 3 through February 28, 1994, excluding weekends and holidays.

Sources: Regression Results: Energy Information Administration, Office of Oil and Gas; derived from: Henry Hub Spot Prices-Pasha Publications, Inc., Gas Daily, and Cold Weather Index-temperature data from National Oceanic and Atmospheric Administration, National Climatic Data Center. (See Appendix D.) 


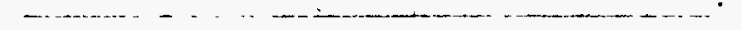




\section{Changes in Storage Operations}

Market and regulatory changes during the past several years, culminating with Order 636, have led to an increased role in the gas industry for natural gas storage. The more competitive environment has required market participants to explore new approaches to the use of storage facilities, develop new services, and propose substantial additions to existing storage capacity. Some of the trends and new developments within the storage industry include:

- More emphasis on inventory management. Under the separate pricing of storage services and the existence of a futures market, the cost and dollar value of storage services and the need to minimize the price risk of holding gas in storage are receiving individual attention for the first time. Inventory management is receiving greater attention, with increased injection and withdrawal activities throughout the year.

- Surge in new storage construction, particularly high-deliverability salt cavern facilities. Since 1989, the ability to deliver gas from storage has increased by nearly 10 percent. More than one-third of the 21 existing salt cavern storage operations have been brought on line since 1991, adding 29 billion cubic feet (Bcf) of working gas capacity and 3.1 Bcf per day of deliverability-increases of 55 and 81 percent, respectively, for this reservoir type. This development is, in part, a response to the overall growth in individual customer transactions, the increased chances of system imbalances because of the variety of transportation arrangements, and the need for a quickresponse mechanism to manage operations.

- Interest in market-based rates. Several companies have asked the Federal Energy Regulatory Commission (FERC) to consider market-based rates for storage services from new as well as existing storage facilities. To date only a few requests have been allowed. The applicant must demonstrate a lack of market power, and this can be difficult except for those relatively smaller facilities in areas where substantial storage options are already available. The spread of market-based rates within the industry may depend in large measure on the markets for released transportation and storage capacity-two key elements of Order 636.

- Development of a secondary market for storage capacity. As with firm transportation capacity, Order 636 requires interstate storage operators to allow their customers to release or sublet unused firm storage capacity to third-party shippers. In the secondary market, owners of unwanted storage capacity have an economic incentive to sell or release the capacity to help defray at least a portion of the cost of reserving capacity. Unneeded capacity that is not resold has no economic value. Very few storage releases have occurred since the implementation of Order 636 in November 1993, perhaps because shippers are reluctant to sell their storage capacity rights until they gain more experience directly managing their systems. It may also be that storage capacity is being rebundled with natural gas and transportation service and sold in the "gray market." 25

This chapter discusses these new developments, paying particular attention to increased storage utilization and plans for new storage capacity. It should be noted that accounting changes by several major storage operators in 1992 and 1993 have resulted in reclassification of base gas levels (see Appendix C). To simplify comparisons of storage operations between years, historical working gas data presented in this chapter have been revised to reflect the current base gas classification.

\section{Inventory Management}

Large amounts of interstate storage capacity were opened to transportation customers when Order 636 provisions were fully implemented on November 1, 1993. However, even before implementation of Order 636, the percentage of working gas in storage owned by interstate pipeline companies had been declining steadily. The percentage of total working gas in interstate storage owned by storage operators at the start of the heating season fell from 73 percent in 1986 to 46 percent in 1993 (Figure 17). ${ }^{26}$ Under their Order 636 restructuring filings, interstate storage operators were allowed to retain some of their working gas

\footnotetext{
${ }^{25}$ The gray market includes all transactions involving unneeded firm interstate transportation or storage capacity that avoid the capacity release posting requirements specified in FERC Order 636. See Philip M. Marston, "The Rumble of Bundles: A Review of Experience Under the Capacity Release Experiment" (Hadson Gas Systems, Inc., August 1994). Many of these transactions involve pre-Order 636 buy-sell agreements that are exempt from the capacity release program. See the "Storage Capacity Release" section in this chapter for more discussion.

${ }^{26} 1993$ is the last year for which the EIA-191, "Underground Gas Storage Report" survey collected this information.
} 


\section{Figure 17. As Order 636 Takes Effect, Storage Volumes Owned by Interstate Pipeline Companies}

Continue to Decline

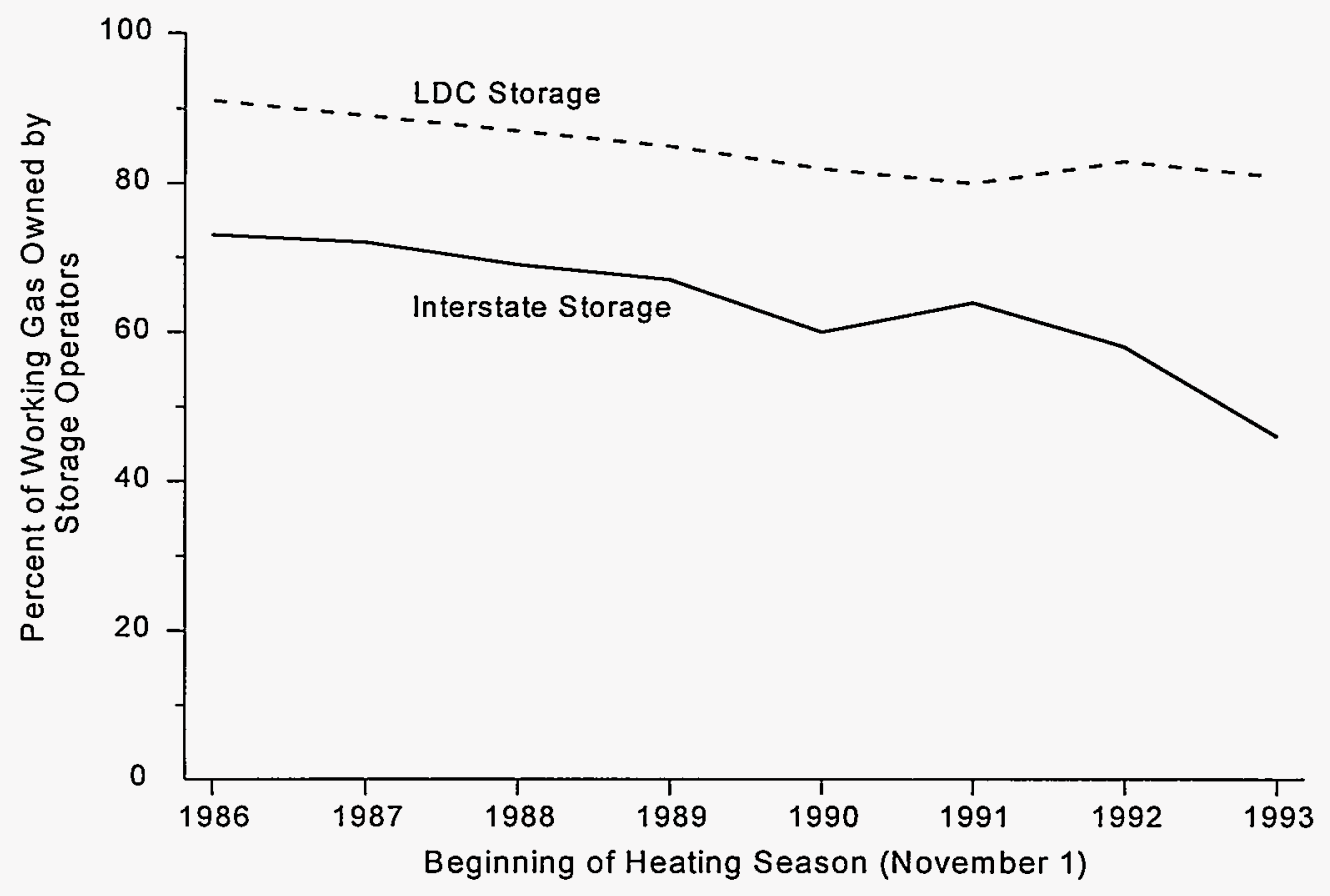

LDC $=$ Local distribution company.

Note: Order 636 became effective on November 1, 1993

Source: 1986-1990: Energy Information Administration, EIA-191/FERC-8, "Underground Gas Storage Report." 1991-November 1, 1993: Energy Information Administration, EIA-191, "Underground Gas Storage Report."

capacity to meet their system requirements for load balancing, system management, and providing "no-notice" service. ${ }^{27}$

As customers have increasingly taken responsibility for contracting for storage services, thereby managing the costs associated with storage use, inventory management practices have changed. During the period from 1989 through 1993, storage utilization per field increased significantly in comparison with the 5-year period from 1982 through 1986 (Table 1). The earlier period reflects the natural gas industry under its "old," highly regulated structure, whereas the later period represents the industry well in transition toward deregulation of most aspects of its operations. By 1989 the effects of Order 436 (open-access transportation programs) were well incorporated into industry operations, and by 1991 the industry was anticipating Order 636.

In comparison with the earlier period, average injection and withdrawal activities per field uniformly increased during the period from 1989 through 1993. This trend held true for nonheating seasons, heating seasons, and heating years alike.

\footnotetext{
${ }^{27}$ No-notice transportation service allows shippers to receive delivery on demand, up to their firm entitlements, without incurring penalties.
}

The increase in monthly average activity levels was substantial. Injection activity during the nonheating season increased by 20 percent while withdrawals increased by 47 percent. Monthly withdrawals during the heating season were up by 11 percent. This upward shift in withdrawal activity is visually evident in the middle graph of Figure 18, which shows heating season withdrawals after adjusting for weather.

In addition to this trend toward greater injection and withdrawail activity, working gas inventory levels at the beginning of the heating season (November 1) drifted progressively lower from 1990 to 1993 - from 3.5 trillion cubic feet (Tcf) in 1990 to 3.0 Tcf in $1993 .{ }^{28}$ Working gas inventories at the end of the heating season also dropped significantly in 1992, 1993, and 1994, both in volume and as a percentage of working gas capacity. Between 1985 and 1991 , end-of-season inventories ranged from 32 to 43 percent of capacity. In 1992, inventories were 32 percent of capacity and after the severe weather in 1993 and 1994 dropped to 24 percent and 26 percent, respectively.

\footnotetext{
${ }^{28}$ Energy Information Administration, Natural Gas Monthly, DOE/EIA0130(92/02) (Washington, DC, February 1992), Table 17; and Natural Gas Monthly, DOE/EIA-0130(94/12) (Washington, DC, December 1994), Table 13.
} 
Table 1. Monthly Natural Gas Injections, Withdrawals, and Working Gas Levels, Heating Years, 1982-83 Through 1986-87 and 1989-90 Through 1993-94 (Million Cubic Feet)

\begin{tabular}{|c|c|c|c|c|c|c|c|c|c|c|c|c|}
\hline \multirow[b]{2}{*}{ Period } & \multicolumn{4}{|c|}{ Average Injections per Field } & \multicolumn{4}{|c|}{ Average Withdrawals per Field } & \multicolumn{4}{|c|}{ Average Working Gas per Field } \\
\hline & $\begin{array}{l}1982-83 \\
\text { Through } \\
1986-87\end{array}$ & $\begin{array}{l}1989-90 \\
\text { Through } \\
1993-94\end{array}$ & $\begin{array}{l}\text { Volume } \\
\text { Change }\end{array}$ & $\begin{array}{l}\text { Percent } \\
\text { Change }\end{array}$ & $\begin{array}{l}1982-83 \\
\text { Through } \\
1986-87\end{array}$ & $\begin{array}{l}1989-90 \\
\text { Through } \\
1993-94\end{array}$ & $\begin{array}{l}\text { Volume } \\
\text { Change }\end{array}$ & $\begin{array}{l}\text { Percent } \\
\text { Change }\end{array}$ & $\begin{array}{l}1982-83 \\
\text { Through } \\
1986-87\end{array}$ & $\begin{array}{l}1989-90 \\
\text { Through } \\
1993-94\end{array}$ & $\begin{array}{l}\text { Volume } \\
\text { Change }\end{array}$ & $\begin{array}{l}\text { Percent } \\
\text { Change }\end{array}$ \\
\hline \multicolumn{13}{|l|}{$\begin{array}{l}\text { Nonheating } \\
\text { Season }\end{array}$} \\
\hline $\begin{array}{l}\text { April } \\
\text { May } \\
\text { June } \\
\text { July } \\
\text { August } \\
\text { September } \\
\text { October } \\
\text { Monthly } \\
\text { Average }\end{array}$ & $\begin{array}{l}449 \\
832 \\
864 \\
922 \\
862 \\
787 \\
584\end{array}$ & $\begin{array}{r}577 \\
1,017 \\
1,061 \\
1,016 \\
991 \\
960 \\
717\end{array}$ & $\begin{array}{r}128 \\
185 \\
197 \\
94 \\
129 \\
173 \\
133\end{array}$ & $\begin{array}{l}29 \\
22 \\
23 \\
10 \\
15 \\
22 \\
23\end{array}$ & $\begin{array}{c}305 \\
89 \\
70 \\
82 \\
101 \\
68 \\
164\end{array}$ & $\begin{array}{l}377 \\
137 \\
109 \\
129 \\
147 \\
134 \\
260\end{array}$ & $\begin{array}{l}72 \\
48 \\
39 \\
47 \\
46 \\
66 \\
96\end{array}$ & $\begin{array}{l}24 \\
54 \\
56 \\
57 \\
46 \\
97 \\
59\end{array}$ & $\begin{array}{l}3,616 \\
4,359 \\
5,153 \\
5,993 \\
6,754 \\
7,472 \\
7,892\end{array}$ & $\begin{array}{l}3,849 \\
4,737 \\
5,687 \\
6,575 \\
7,419 \\
8,214 \\
8,676\end{array}$ & $\begin{array}{l}233 \\
378 \\
534 \\
582 \\
665 \\
742 \\
784\end{array}$ & $\begin{array}{r}6 \\
9 \\
10 \\
10 \\
10 \\
10 \\
10\end{array}$ \\
\hline \multicolumn{13}{|l|}{$\begin{array}{l}\text { Heating } \\
\text { Season }\end{array}$} \\
\hline $\begin{array}{c}\text { November } \\
\text { December } \\
\text { January } \\
\text { February } \\
\text { March } \\
\text { Monthly } \\
\text { Average }\end{array}$ & $\begin{array}{l}264 \\
158 \\
112 \\
151 \\
249 \\
\\
\\
187\end{array}$ & $\begin{array}{l}342 \\
239 \\
220 \\
173 \\
311 \\
\\
257\end{array}$ & $\begin{array}{r}78 \\
81 \\
108 \\
22 \\
62\end{array}$ & $\begin{array}{l}30 \\
51 \\
96 \\
15 \\
25\end{array}$ & $\begin{array}{r}572 \\
1,285 \\
1,673 \\
1,166 \\
799\end{array}$ & $\begin{array}{c}757 \\
1,456 \\
1,535 \\
1,384 \\
997\end{array}$ & $\begin{array}{l}185 \\
171 \\
138 \\
218 \\
198\end{array}$ & $\begin{array}{l}32 \\
13 \\
-8 \\
19 \\
25\end{array}$ & $\begin{array}{l}7,401 \\
6,274 \\
5,041 \\
4,026 \\
3,476 \\
\\
\\
5,247\end{array}$ & $\begin{array}{l}8,356 \\
7,072 \\
5,551 \\
4,340 \\
3,655\end{array}$ & $\begin{array}{l}955 \\
798 \\
510 \\
314 \\
179\end{array}$ & $\begin{array}{r}13 \\
13 \\
10 \\
8 \\
5\end{array}$ \\
\hline $\begin{array}{l}\text { Heating } \\
\text { Year } \\
\text { Monthly } \\
\text { Average }\end{array}$ & 520 & 642 & 122 & 23 & 531 & 644 & 113 & 21 & 5,623 & 6,160 & 537 & 10 \\
\hline
\end{tabular}

Note: Before 1991, data were available only on a company-wide basis. For field-level data prior to January 1991, company totals were apportioned based on the January 1991 ratio of the field's working capacity to the company total working gas capacity. Only those fields active throughout the 1982-1993 period were included. A heating year is from April of one year through March of the next year, for example, April 1982 through March 1983 is the $1982-83$ heating year. Data are not adjusted for weather.

Sources: 1982-83 through 1990-91: Energy Information Administration, EIA-191/FERC-8, "Underground Gas Storage Report." $1991-92$ through 1993-94: Energy Information Administration, EIA-191, "Underground Gas Storage Report."

As the industry adjusted to the more competitive environment under open-access transportation programs, the lower monthly inventories and increased injection and withdrawal activities throughout the year seem to indicate a fundamental adjustment relating to the economics of storage use and a reassessment of what storage levels are adequate for supply reliability. Certainly, the progressively lower inventory levels from 1991 through 1993 for any given nonheating season month equate to money saved on inventory costs and imply that management of stored gas was becoming more efficient.

Changes in inventory management occurred in 1994, however, that reversed some of these recent trends (Figure 19). By contrast to the past few years, the percentage of working gas capacity filled in 1994 was higher at the start of the nonheating season than it had been the preceding year, and by September had exceeded the point reached at the same time in the three previous years. By the beginning of the 1994-95 heating season, the percentage had reached 83 percent.

Another recent deviation has been the decline in weatheradjusted withdrawal activity during the past two heating seasons (Figure 18). Some of this change is attributable to the effects of capacity constraints on storage assets: less storage capacity was available for nonweather-related activities as winter weather in the past two heating seasons returned to normally cold temperatures (after the three preceding heating seasons of warmer-than-normal weather). However, the larger decline in the 1993-94 heating season may be attributed to the changes taking place in inventory management and operations during the first heating season under Order 636. Beginning November 1, 1993, a significant proportion of working gas capacity previously managed by interstate pipeline companies 
Figure 18. Utilization of Storage Facilities Has Increased During the Heating Seasons
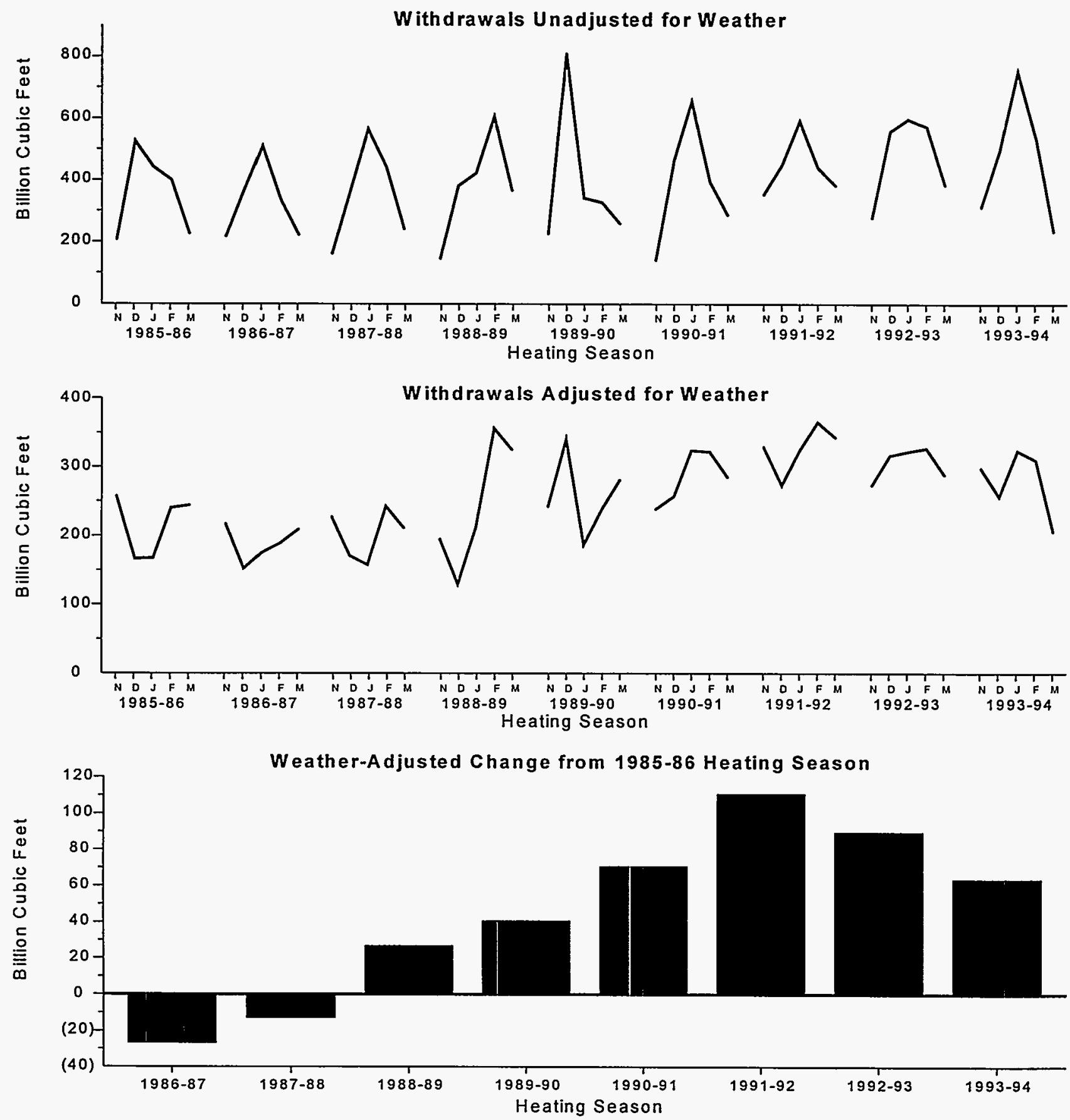

Note: Because vertical scales differ, graphs should not be directly compared. Monthly withdrawals have been adjusted for weather by subtracting the estimated influence of heating degree days from withdrawals. The estimated influence is obtained by regressing withdrawals on heating degree days.

Sources: 1985-86 through 1990-91: Energy Information Administration, EIA-191/FERC-8, "Underground Gas Storage Report." 1991-92 through 1993-94: Energy Information Administration, ElA-191, "Underground Gas Storage Report." Heating Degree Days: National Oceanic and Atmospheric Administration, National Climatic Data Center. 
Figure 19. Storage Capacity Utilization in 1994 Reversed the Declining Trend, Moving Higher Than 1991 Levels Near the End of the Nonheating Season

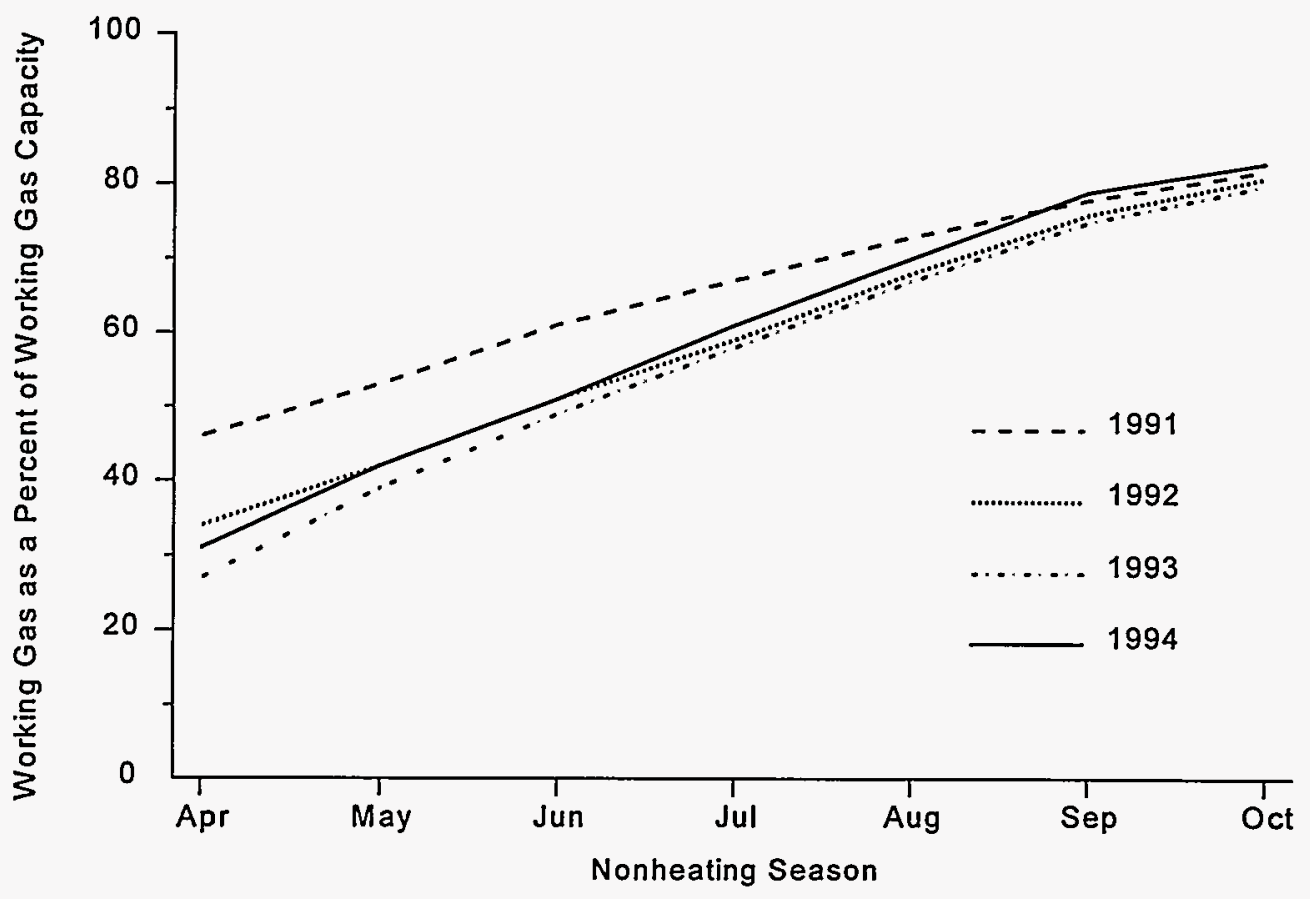

Source: Energy Information Administration, EIA-191, "Underground Gas Storage Report."

on behalf of their bundled sales customers became the responsibility of these former sales customers as well as some new customers.

The uncertainties associated with this transition to unbundled storage service have fostered a certain degree of caution, particularly for those customers less experienced in managing inventories. Perhaps more importantly, individual customers are making their own decisions about inventory requirements, which in aggregate may require greater capacity than if pipeline companies, with their system-wide approach, still controlled storage levels. Further, because many of these customers are local distribution companies (LDC's) with a service obligation to end-use customers, they may tend to err on the side of holding too much inventory rather than too little. Finally, the increased ratio of working gas to working gas capacity can be attributed partly to customers taking advantage of a drop in spot market prices that began in August 1994.

Unbundled storage services provide users with a means to evaluate more closely their use of storage relative to their specific needs and purchasing strategies. For those customers who have just recently begun to cope with unbundled services, it is not surprising that 1994 would be a year of cautious operations. And, with customers making their own inventory management decisions, an upward shift in aggregate inventory levels may occur. In the future, howe'er, as storage users become more accustomed to managing their own inventories, the trend toward lower levels of working gas in storage, and for increasing weather-adjusted withdrawals, may resume.

\section{New Market Requirements Are Driving Storage Expansions}

Order 636 and significant new developments in supply and demand conditions have required market participants to explore new approaches to the use of storage facilities, develop new services, and propose substantial additions to existing storage capacity. Although additions to underground storage capacity for the traditional seasonal services of augmenting mainline transmission capacity continue to be proposed, a substantial portion of the proposed additions have very different characteristics. These include: (1) rapid inventory turnover capability, (2) location in the Gulf Coast producing region or near new transmission capacity, (3) sponsorship by independent developers rather than interstate pipeline companies, (4) year-round capability for withdrawal and injection, and (5) little or no notice required for withdrawal and injection. 
The prevalence of these nontraditional characteristics is, in part, an attempt by sellers of storage services to take advantage of the new opportunities offered by an increasingly unregulated natural gas market. It is also the result of increasing demands for new services by storage customers. In addition to traditional seasonal storage services, there is increased interest in:

- Supply balancing-the daily and/or monthly reconciliation of nominations and deliveries between buyers and sellers of gas

- Emergency backup - the use of storage as a backup source of supply in the event of a production failure or the nondelivery of gas

- No-notice-the assured delivery of the difference between a customer's daily nomination and what the customer actually required on that day

- Price hedging - the use of storage to hedge seasonal or shorter time period differentials in gas prices.

These services require significantly more operational flexibility than provided by traditional seasonal supply service. This includes such characteristics as the ability to inject and withdraw gas on a continuing basis throughout the year to balance daily or monthly demands and the ability to withdraw large quantities of gas quickly and reliably to meet surges in demand or replace lost production.

The new service requirements and growth in demand are behind the surge of interest in new underground gas storage construction (Table 2). If all proposed projects were completed as planned, working gas capacity would increase more than 13 percent by 1999 from the level in 1993. Deliverability would increase by 31 percent, with much more capacity owned by independent companies (Figure 20). With the exception of projects that are actually under construction, however, it is difficult to determine which proposals will have sufficient customer commitment, adequate financing, and necessary regulatory approvals to be built and become operational.

Of the 24 projects that were originally planned to come on line in 1993, 15 were actually completed and the rest were deferred to 1994 (Table 3). Completed projects expanded existing working gas capacity by $97 \mathrm{Bcf}$ and daily deliverability by 3.7 Bcf. These projects represented 67 percent of planned additions to working gas capacity for 1993 and 77 percent of planned additions to daily deliverability. (As of November 1994, at least three of the deferred projects had been completed; the others are in various stages of development/implementation.)
The majority of completed projects are owned by interstate pipeline companies, accounting for 67 percent of the added working gas capacity, but only 37 percent of the added peakday deliverability. Interstate pipeline companies were also the most successful in implementing announced additions to working gas capacity and deliverability, adding 90 percent and 88 percent, respectively, of what was originally planned. Only one of the five scheduled projects by independent operators was brought on line in 1993, yet it accounted for roughly 20 percent of the total of both new working gas capacity and new daily deliverability in 1993. While 79 percent of total new working gas capacity brought on line in 1993 was in depleted oil/gas fields, this reservoir type accounted for only 37 percent of total additional deliverability; the rest, or 63 percent, was implemented in salt formation facilities.

Most of the added deliverability is from facilities in the Southwest (2,280 million cubic feet (MMcf) per day) and the Midwest ( $720 \mathrm{MMcf}$ per day), with working gas capacity increasing by $30.7 \mathrm{Bcf}$ and $42.4 \mathrm{Bcf}$, respectively. The only other region to figure significantly in capacity additions was the Northeast, which installed $18.0 \mathrm{Bcf}$ of new working gas capacity, representing 19 percent of total 1993 additions.

\section{Competitive Pressures Foster Some Abandonments}

The 1990's is expected to be a major development period for underground storage. Nevertheless, since 1990, a number of existing storage sites have been placed into inactive or standby mode while several more have abandonment applications pending before FERC or State public utility commissions (Table 4).

With respect to a storage field's status, the term "abandoned" has an official, specific meaning. To abandon a field, the operator must obtain permission from the appropriate regulatory agency(ies) and must make certain modifications to the physical characteristics of the field. For example, at a minimum the operator would be required to plug each well, dismantle and dispose of all above-ground equipment associated with each well, and dispose of other above-ground assets that might be safety hazards. The operator very likely would be required to accomplish some measure of environmental restoration or remediation, and might also be required to remove some of the below-ground equipment (e.g., well casings), particularly if it might in some way endanger environmental integrity at the site. 
Table 2. Proposed New and Expansion Underground Storage Projects in the United States, 1994-1999

\begin{tabular}{|c|c|c|c|c|c|c|c|c|}
\hline \multirow{2}{*}{ Type of Project } & \multicolumn{3}{|c|}{$\begin{array}{l}\text { Number of } \\
\text { Projects }\end{array}$} & \multirow{2}{*}{\begin{tabular}{|} 
Additions to \\
Base Gas \\
Capacity \\
(Bct)
\end{tabular}} & \multirow{2}{*}{$\begin{array}{c}\text { Additions to } \\
\text { Working Gas } \\
\text { Capacity } \\
\text { (Bcf) }\end{array}$} & \multirow{2}{*}{$\begin{array}{c}\text { Total Additions } \\
\text { to Storage } \\
\text { Capacity } \\
\text { (Bcf) }\end{array}$} & \multirow{2}{*}{$\begin{array}{c}\text { Additions to } \\
\text { Withdrawal } \\
\text { Capacity } \\
\text { (MMcf/d) }\end{array}$} & \multirow{2}{*}{$\begin{array}{l}\text { Additions to } \\
\text { Injection } \\
\text { Capacity } \\
\text { (MMcf/d) }\end{array}$} \\
\hline & New & $\begin{array}{c}\text { Expan- } \\
\text { sion }\end{array}$ & Total & & & & & \\
\hline 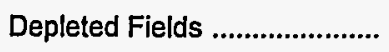 & 24 & 7 & 31 & 253 & 322 & 575 & 6,521 & 3,124 \\
\hline 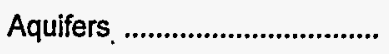 & 1 & 2 & 3 & 9 & 9 & 19 & 110 & 45 \\
\hline \multicolumn{9}{|l|}{ Salt Caverns ${ }^{a}$} \\
\hline Salt Domes ............................. & 13 & 15 & 28 & 49 & 103 & 152 & 8,905 & 3,245 \\
\hline 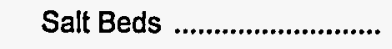 & 9 & 10 & 19 & 16 & 61 & 77 & 5,210 & 1,390 \\
\hline Total Salt Formations .... & 22 & 25 & 47 & 65 & 164 & 230 & 14,115 & 4,635 \\
\hline Total Projects ${ }^{b}$ & 47 & 34 & 81 & 328 & 495 & 824 & 20,746 & 7,804 \\
\hline
\end{tabular}

asalt cavern storage is prepared by injecting water (leaching) into a salt formation (either a salt bed or salt dome) and shaping a cavern. Salt beds are more expensive to develop than salt domes because in general they are thinner formations (about 1,000-feet thick vs. up to 30,000 feet), which makes them more susceptible to deterioration.

bAnnounced as of February 28, 1994.

Bcf = Billion cubic feet. MMcf/d = Million cubic feet per day.

Note: Two liquefied natural gas storage projects (one new, one expansion) have also been proposed, which would add 4 Bcf working gas capacity, 1,000 MMcf/d withdrawal capacity, and $15 \mathrm{MMcf} / \mathrm{d}$ injection capacity. Totals may not equal sum of components because of independent rounding.

Source: Energy Information Administration, Office of Oil and Gas, "Proposed Natural Gas Storage Projects," data base as of October 31, 1994, based on Federal Energy Regulatory Commission filings and information from vảrious industry news sources.

Figure 20. Independent Operators Are Projected to Play a Larger Role in Storage by the End of the Decade

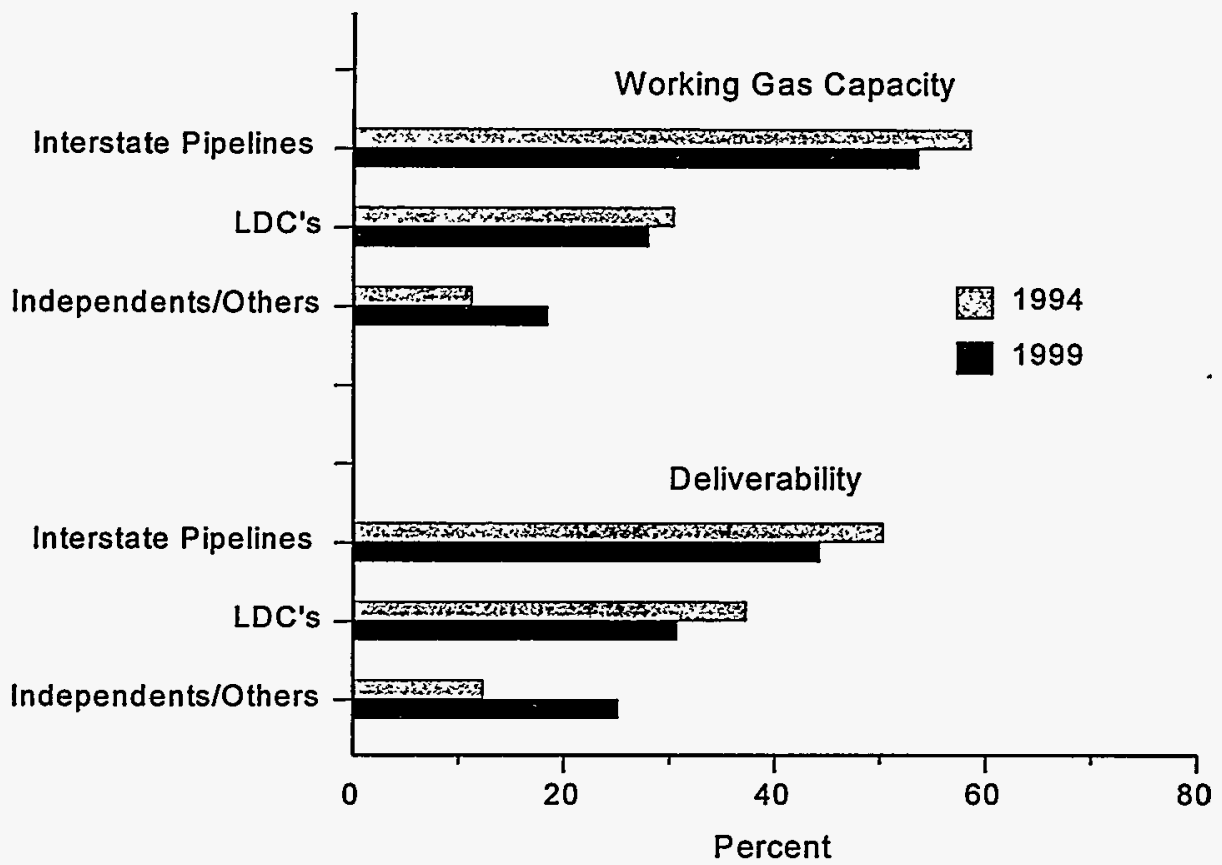

LDC's = Local distribution companies.

Sources: Energy Information Administration (EIA). 1994: EIA-191, "Underground Gas Storage Report." 1999: Office of Oil and Gas, "Proposed Natural Gas Storage Projects," data base as of October 31, 1994, based on Federal Energy Regulatory Commission filings and information from various industry news sources. 
Table 3. Planned Versus Actual Storage Additions, 1993

\begin{tabular}{|c|c|c|c|c|c|c|c|c|c|c|c|}
\hline \multirow[b]{2}{*}{ Type } & \multicolumn{4}{|c|}{ Planned for 1993} & \multicolumn{4}{|c|}{ In Service by 1993} & \multicolumn{3}{|c|}{$\begin{array}{c}\text { Percent of Planned } \\
\text { Projects In Service by } 1993\end{array}$} \\
\hline & $\begin{array}{c}\text { Number } \\
\text { of } \\
\text { Projects }\end{array}$ & $\begin{array}{l}\text { Base } \\
\text { Gas } \\
\text { (Bcf) }\end{array}$ & $\begin{array}{l}\text { Working } \\
\text { Gas } \\
\text { Capacity } \\
\text { (Bcf) }\end{array}$ & $\begin{array}{l}\text { Deliver- } \\
\text { ability } \\
\text { (MMcf/d) }\end{array}$ & $\begin{array}{c}\text { Number } \\
\text { of } \\
\text { Projects }\end{array}$ & $\begin{array}{l}\text { Base } \\
\text { Gas } \\
\text { (Bcf) }\end{array}$ & $\begin{array}{l}\text { Working } \\
\text { Gas } \\
\text { Capacity } \\
\text { (Bcf) }\end{array}$ & $\begin{array}{l}\text { Deliver- } \\
\text { ability } \\
\text { (MMcf/d) }\end{array}$ & $\begin{array}{l}\text { Base } \\
\text { Gas } \\
\text { (Bcf) }\end{array}$ & $\begin{array}{c}\text { Working } \\
\text { Gas } \\
\text { Capacity } \\
\text { (Bcf) }\end{array}$ & $\begin{array}{l}\text { Deliver- } \\
\text { ability } \\
\text { (MMcf/d) }\end{array}$ \\
\hline \multicolumn{12}{|l|}{$\begin{array}{l}\text { Reservoir } \\
\text { Type }\end{array}$} \\
\hline Aquifer & 2 & 15 & 13 & 160 & 0 & 0 & 0 & 0 & 0 & 0 & 0 \\
\hline $\begin{array}{l}\text { Depleted } \\
\text { Field }\end{array}$ & 13 & 41 & 97 & 1,663 & 8 & 27 & 77 & 1,373 & 65 & 79 & 83 \\
\hline $\begin{array}{l}\text { Salt } \\
\text { Formation }\end{array}$ & 9 & 17 & 34 & 2,950 & 7 & 8 & 20 & 2,300 & 49 & 58 & 78 \\
\hline \multicolumn{12}{|l|}{$\begin{array}{l}\text { Project } \\
\text { Type }\end{array}$} \\
\hline New & 13 & 42 & 111 & 3,755 & 8 & 23 & 80 & 3,109 & 54 & 72 & 83 \\
\hline Expansion & 11 & 31 & 33 & 1,018 & 7 & 12 & 16 & 564 & 39 & 49 & 55 \\
\hline \multicolumn{12}{|l|}{ Ownership } \\
\hline Independent & 5 & 18 & 34 & 1,005 & 1 & 7 & 20 & 720 & 41 & 58 & 72 \\
\hline $\begin{array}{c}\text { Interstate } \\
\text { Pipeline }\end{array}$ & 11 & 28 & 72 & 1,553 & 8 & 25 & 65 & 1,373 & 88 & 90 & 88 \\
\hline $\begin{array}{r}\text { Intrastate } \\
\text { Pipeline }\end{array}$ & 5 & 11 & 21 & 1,440 & 4 & 1 & 7 & 1,230 & 12 & 31 & 85 \\
\hline LDC & 3 & 16 & 17 & 775 & 2 & 2 & 5 & 350 & 9 & 31 & 45 \\
\hline Total & 24 & 73 & 144 & 4,773 & 15 & 35 & 97 & 3,673 & 48 & 67 & 77 \\
\hline
\end{tabular}

Bcf = Billion cubic feet. MMcf $/ d=$ Million cubic feet per day. $L D C=$ Local distribution company.

Note: Totals may not equal sum of components because of independent rounding.

Sources: Energy Information Administration (EIA). In Service: EIA-191, "Underground Gas Storage Report." Planned: Office of Oil and Gas, "Proposed Natural Gas Storage Projects," data base as of October 31, 1994, based on Federal Energy Regulatory Commission filings and information from various industry news sources.

Table 4. Changes to Working Gas Capacity and Daily Deliverability, 1990-1993

\begin{tabular}{c|c|c|c|c|c|c|c|c|c|}
\hline & \multicolumn{3}{|c|}{ In Service } & \multicolumn{3}{c|}{ New } & \multicolumn{3}{c}{ Removed from Service } \\
\cline { 2 - 10 } Year & $\begin{array}{c}\text { Number } \\
\text { of } \\
\text { Sites }\end{array}$ & $\begin{array}{c}\text { Working } \\
\text { Gas } \\
\text { Capacity } \\
\text { (Bcf) }\end{array}$ & $\begin{array}{c}\text { Daily } \\
\text { Deliver- } \\
\text { ability } \\
\text { (MMcf/d) }\end{array}$ & $\begin{array}{c}\text { Number } \\
\text { of } \\
\text { Sites }\end{array}$ & $\begin{array}{c}\text { Working } \\
\text { Gas } \\
\text { Capacity } \\
\text { (Bcf) }\end{array}$ & $\begin{array}{c}\text { Daily } \\
\text { Deliver- } \\
\text { ability } \\
\text { (MMcf/d) }\end{array}$ & $\begin{array}{c}\text { Number } \\
\text { of } \\
\text { Sites }\end{array}$ & $\begin{array}{c}\text { Working } \\
\text { Gas } \\
\text { Capacity } \\
\text { (Bcf) }\end{array}$ & $\begin{array}{c}\text { Daily } \\
\text { Deliver- } \\
\text { ability } \\
\text { (MMcf/d) }\end{array}$ \\
\hline 1990 & 357 & 3,550 & 61,718 & 1 & 2 & 450 & 4 & 7 & 72 \\
1991 & 366 & 3,596 & 63,506 & 9 & 46 & 1,740 & 8 & 7 & 120 \\
1992 & 367 & 3,598 & 64,056 & 1 & 2 & 500 & 12 & 14 & 81 \\
1993 & 375 & 3,695 & 67,729 & 8 & 80 & 3,109 & 5 & 244 \\
\hline
\end{tabular}

'Includes expansions to existing capacity/deliverability that occurred during the year. Excludes abandoned, inactive, and standby sites. Bcf = Billion cubic feet. MMcf/d = Million cubic feet per day.

Source: Energy Information Administration, Office of Oil and Gas; derived from ElA-191, "Underground Gas Storage Report." 
On the other hand, the terms "inactive" and "standby," at least as used here, do not refer to any officially-sanctioned status. The intended meanings of these terms were implied through their use by storage operators in conversations about their operations. Thus, for purposes of this discussion, an inactive field is tantamount to being abandoned. The operator has removed or is removing all working gas and, usually, is recovering or will attempt to recover all base gas for which recovery is economical. The operator is doing virtually no maintenance on the field. In some cases, operators with inactive fields have already filed, or intend to file, the necessary paperwork for official abandonment, but this is not always the case. Some operators have indicated that they will merely leave the fields in an inactive state for an unspecified period of time.

Standby fields are those that are not actively in use, but are being maintained and can be brought back into service in a relatively short period of time. Usually, the operator has withdrawn or is withdrawing all working gas, but base gas is being left in place.

Of the 29 storage sites taken out of service from 1990 through 1993 , at least 13 , and perhaps as many as 21 , have been or are being depleted and will be abandoned or left inactive. Most of the 21 are considered by their owners to be uneconomical to operate in today's marketplace without incurring a major workover expense; a few are inactive because continued operation would raise safety concerns. The remaining 8 of the 29 sites are classified as standby by their operators; that is, they contain no working gas, and, other than withdrawing remaining recoverable gas or operations to maintain standby status, minimal activity has been reported. All but 2 of the 29 deactivated sites are depleted gas/oil reservoirs, with the others aquifer sites. For the most part, they are small fields. Nine are located in the Northeast, seven in the Midwest, six in the Southwest, and four in the Central Region. Two are located in Kentucky (Southeast) and one in California (Western).

A close examination of the types of storage fields that have been taken out of service tends to show how, with the growth of open access storage and increased need by operators to market storage services, marginal and poorly located storage may be falling victim to economics and a changing market environment. Some of the reasons given for inactivating or abandoning particular storage sites are:

- Need major workovers; leaking casings, seepage, etc. (four sites)

- Too small a field to support itself (four sites)
- Substantial migration losses (three sites) ${ }^{29}$

- Safety (three sites)

- Located at nonstrategic place on system (two sites)

- Loss of a key and only client (one site).

In total, since the early 1970 's, as many as 82 storage facilities in the United States have been officially abandoned, classified as standby, or are simply no longer being used.$^{30}$ However, their daily deliverability is only 1.8 percent of total storage deliverability in 1994. In contrast, the new sites brought into service from 1990 through 1993 increased daily deliverability by 9.2 percent $(5,694$ million cubic feet).

It appears then that new underground storage development has not created a surplus of storage capacity, at least for now, as some have argued. New storage capacity has not displaced existing capacity; rather, it has been the marketplace that has culled the marginal operations from the Nation's storage inventory. Also, it is worth noting that standby sites, as well as a number of the inactive sites, have not been totally abandoned and could be reactivated in the future.

\section{The Emphasis on Salt Cavern and Other High-Deliverability Storage}

Another new characteristic of the storage market is the increasing reliance on salt cavern storage. Most salt cavern facilities are designed with the intent of cycling the entire working gas capacity 5 to 10 times each year. Typical injection periods are in the range of 20 days. In contrast, more traditional storage, such as storage in depleted reservoirs, is
Migration is the subsurface movement of oil, gas, or water through porous and permeable rock. Migration losses occur when gas molecules find pathways beyond the confines of the storage reservoir's cap rock (the generally impermeable layer that halts upward migration of gas). Such losses are usually because of the geologic configuration of the reservoir but may be intensified by man-made development activities or reservoir operating procedures. provided by respondents to EIA-191, "Underground Gas Storage Report,

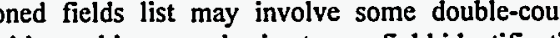
ambiguities and inaccuracies in storage field identification, just as it may also exclude some abandoned fields for which no information is available. 
normally cycled only once each year and typically requires 200 days to refill. ${ }^{31}$

While salt cavern storage accounts for only 2 percent of total working gas capacity, it can provide 11 percent of available storage deliverability on a peak day. In 1993, there were 18 active salt cavern sites, 11 of which had been developed since 1986. This type of storage provides a great deal of flexibility for quick withdrawals and refills. Because of its ability to cycle the gas quickly, salt cavern storage is potentially very useful for supporting the increased load-balancing requirements of the industry, the new electric generation requirements for combined-cycle plants, ${ }^{32}$ and as supply for no-notice service.

Withdrawals from salt cavern storage account for an increasing percentage of monthly storage withdrawals, particularly during the nonheating season (Figure 21) when most depleted reservoir storage is in the injection phase of its annual cycle. Although withdrawals from salt cavern storage represented less than 4 percent of total withdrawals during each of the heating seasons from 1989 to 1993, they accounted for 19 percent in the 1994 nonheating season. Many of today's salt cavern storage customers are electric utilities in Texas, who are increasingly using highdeliverability storage for very short-term peaking purposes. Depending on summer temperatures and resulting electric generation needs, utilities may cycle their storage inventories many times in the summer months.

Although its role is clearly increasing (see box, p. 36), salt cavern storage facilities have limited working gas volumes and are still being used primarily for peaking operations. Further, it appears that one of the major advantages of salt cavern storage-its ability for multiple cycling during the year-is yet to be fully exploited. While the ratio of annual total withdrawals to working gas capacity (the number of times that inventory was turned over in a year) for salt cavern storage facilities has slowly edged up, from 1.11 in 1991 to 1.66 in 1993 and an estimated 1.61 in 1994, it remains very low relative to the facilities' capabilities. One possible explanation for the limited utilization of salt storage lies in the rate structure under which the storage service has been offered. Most pre-Order 636 salt cavern storage remains subject to rate-based cost recovery pricing. Thus, storage operators generally have been able to obtain their regulated rate of return on storage operations without multiple cycling

\footnotetext{
"For further information, see Thomas F. Barron, "Underground Storage of Natural Gas," GasMart 1993 (Kansas City, MO, March 8, 1993).

${ }^{32} \mathrm{~A}$ combined-cycle electric generating plant is one that employs gasfired and steam-driven turbines together to increase the efficiency of the electricity generating process. Such plants require gas delivery under high pressure and have widely varying load requirements, which make the highdeliverability capability of salt cavern storage desirable.
}

of the facility. Peaking service is a high-cost service, and in this role, salt storage competes with other high-cost supplemental sources. In the future, salt storage, as well as other high-deliverability storage facilities, may increasingly operate under market-based rates and require multiple inventory turnovers to remain competitive. A number of proposals involving new salt cavern storage facilities have been made to FERC for permission to charge market-based rates (see following section, "Market-Based Rates for Storage Services").

Finally, while it is common to equate high-deliverability rates with salt cavern storage facilities, a number of storage facilities-primarily depleted fields but also one aquifer site and converted mine-that are not salt-formation reservoirs have the ability to withdraw working gas as rapidly as the average salt cavern facility (based on reported working gas capacities and maximum deliverability rates). ${ }^{33}$ The average withdrawal cycle for all salt cavern facilities is slightly less than 12 days, whereas the average for all storage facilities is about 55 days. Nonetheless, 15 nonsalt cavern storage facilities (out of a total of 354) have drawdown periods of 12 days or less. In fact, the average drawdown period for this group of storage facilities is about 7 days.

\section{Market-Based Rates for Storage Services}

An additional characteristic of the new storage market is the increased interest in market-based rates for services. Proponents stress that market-based rates for storage enhance the flexibility or efficiency of the gas industry. One argument is that the absence of regulation and its associated costs saves the company money-savings, which can mean a leaner, more efficient operation; and savings, which can be invested to expand and improve the business. Another argument invokes the classic market economics principle: when goods and services are provided and prices are set in open, competitive markets, competitors are driven to be more efficient.

Market-based rates are a relatively new development in the natural gas industry. The amount of storage capacity subject to market-based rates is quite small (Table 5). So far, FERC has approved only applications relating to individual storage facilities, two of which were operational (Bistineau and

\footnotetext{
${ }^{33}$ For purposes of this discussion, deliverability is defined in terms of the "drawdown period"--the number of days to withdraw the total working gas capacity volume of gas for a given facility at its maximum withdrawal rate (i.e., total working gas capacity divided by maximum withdrawal rate).
} 
Figure 21. Withdrawals from Salt Cavern Storage Show Steady Increases, With Substantial Gains in Nonheating Seasons

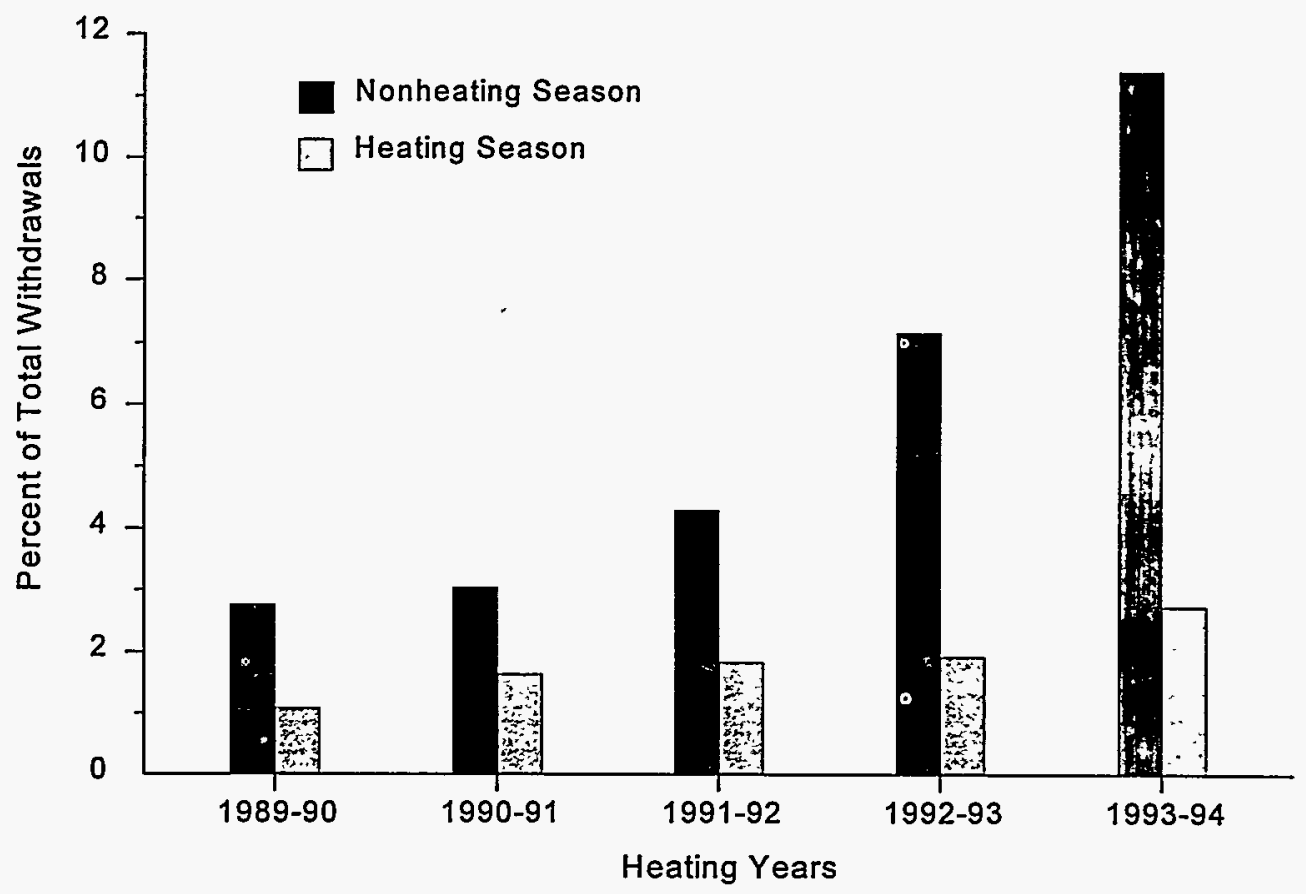

Sources: 1989-1990: Energy Information Administration, EIA-191/FERC-8, "Underground Gas Storage Report." 1991- 1994: Energy Information Administration, EIA-191, "Underground Gas Storage Report."

Greasy Creek) and five of which were in various stages of planning or construction at the time of application.

\section{"Market Power:" The Determining Factor for Market-Based Rates}

To be approved to charge market-based rates, FERC requires the applicant to demonstrate that it lacks market power in the market that it intends to serve. FERC defines market power as "... the ability of a seller profitably to maintain prices above competitive levels for a significant period of time. ${ }^{134}$ Thus, the critical element in a storage provider's application for market-based rates is its analysis of its market and its relative standing in that market.

Thus far, in its review of market-based rate applications, FERC has defined a facility's market as narrowly as possible, both from a geographic standpoint as well as from the standpoint of which products/services are alternatives to the applicant's. FERC's reasoning is that if it can be shown that the applicant cannot wield market power in a narrowly

${ }^{34}$ Federal Energy Regulatory Commission, Bay Gas Storage Company, Lid, 66 FERC § 61,354, at p. 62,189 (1994); Richfield Gas Storage System, 59 FERC $\S 61,316$, at p. 62,167 (1992). defined market, then it certainly will not have market power in broader markets.

In its review of market analyses, FERC relies (although not exclusively) on two numeric measures: a facility's or company's market share, and a related measure, the Herfindahl-Hirschman Index (HHI) of market concentration. ${ }^{35}$ Market share is simply the ratio of the applicant's storage service capacity to total storage capacity in the market. A small HHI means that the market is not concentrated and customers have ample alternatives. FERC defines a "good alternative" as one that "... is available soon enough, has a price that is low enough, and has a quality high enough to permit customers to substitute the alternative. . ." for the service offered by the applicant. ${ }^{36}$

\footnotetext{
${ }^{35}$ The HHI for a market is the sum of the squares of each storage provider's market share. For example, if a particular market has two sellers, with market shares of .75 and .25 , respectively, the HHI is computed as follows: $(.75)^{2}+(.25)^{2}=.5625+.0625=.6250$. The lower the HHI, the less market concentration and the greater likelihood of a competitive market. See Federal Energy Regulatory Commission, CP94-161-000, Avoca Natural Gas Storage, Preliminary Determination on Non-Environmental Issues (July 8, 1994), pp. 13-14.

${ }^{36}$ Federal Energy Regulatory Commission, CP94-161-000, Avoca Natural Gas Storage, Preliminary Determination on Non-Environmental Issues (July 8, 1994), p. 8.
} 


\section{Increasing Importance of Salt Cavern Storage}

The sharp increase in storage withdrawals during the January 1994 cold spell included a somewhat larger share from salt cavern facilities than in January 1993-2.8 percent versus 2.3 percent. Withdrawals from new salt storage facilities accounted for some of the increased share in January 1994, yet most can be attributed to older salt facilities. Withdrawals from these older sites grew from 13.5 billion cubic feet (Bcf) in January 1993 to $18.6 \mathrm{Bcf}$ in January 1994. Total withdrawals from salt cavern storage during January 1994 were 21.4 Bcf.

The heavy demand for storage gas also highlighted the importance of salt cavern facilities for rebuilding storage inventories. Although total storage injections during January were significantly less in 1994 than in 1993, injections into salt cavern storage more than doubled (from 4.2 to $10.9 \mathrm{Bcf}$ ), representing almost one-third of the month's total ( $33.3 \mathrm{Bcf}$ ).

The expanded use of salt cavern storage was maintained throughout the 1993-94 heating season, accounting for 2.8 percent $(66 \mathrm{Bcf})$ of withdrawals and 15.4 percent $(55 \mathrm{Bcf})$ of injections. In comparison, during the previous heating season, salt cavern storage represented 1.9 and 9.0 percent, respectively, of total withdrawals and injections.

Monthly Salt Cavern Injections and Withdrawals, Heating Seasons, 1991-92 Through 1993-94 (Million Cubic Feet)

\begin{tabular}{|c|c|c|c|c|c|c|}
\hline \multirow[b]{2}{*}{ Month } & \multicolumn{3}{|c|}{ Injections } & \multicolumn{3}{|c|}{ Withdrawals } \\
\hline & $1991-92$ & $1992-93$ & $1993-94$ & $1991-92$ & $1992-93$ & $1993-94$ \\
\hline \multicolumn{7}{|l|}{ Heating Season } \\
\hline $\begin{array}{l}\text { November } \\
\text { December } \\
\text { January } \\
\text { February } \\
\text { March }\end{array}$ & $\begin{array}{r}10,511 \\
4,217 \\
2,537 \\
3,105 \\
3,390\end{array}$ & $\begin{array}{l}7,456 \\
5,317 \\
4,218 \\
3,618 \\
6,620\end{array}$ & $\begin{array}{r}10,272 \\
7,922 \\
10,874 \\
12,255 \\
13,696\end{array}$ & $\begin{array}{r}5,756 \\
5,307 \\
11,349 \\
9,808 \\
8,376\end{array}$ & $\begin{array}{r}5,503 \\
4,629 \\
13,524 \\
11,326 \\
10,916\end{array}$ & $\begin{array}{r}5,150 \\
10,733 \\
21,353 \\
20,278 \\
8,758\end{array}$ \\
\hline Total & 23,760 & 27,229 & 55,019 & 40,596 & 45,898 & 66,272 \\
\hline $\begin{array}{l}\text { Percent of } \\
\text { All Storage }\end{array}$ & 5.0 & 9.0 & 15.4 & 1.8 & 1.9 & 2.8 \\
\hline Total Heating Year & 68,685 & 78,265 & 118,342 & 63,942 & 80,067 & 110,240 \\
\hline
\end{tabular}

Source: Energy Information Administration, EIA-191, "Underground Gas Storage Report." 
Table 5. Storage Service Providers Seeking to Charge Market-Based Rates

\begin{tabular}{|c|c|c|c|c|c|c|c|c|}
\hline \multirow[b]{2}{*}{$\begin{array}{l}\text { Application Status/ } \\
\text { Company }\end{array}$} & \multirow[b]{2}{*}{$\begin{array}{c}\text { Date } \\
\text { Applied }\end{array}$} & \multirow[b]{2}{*}{$\begin{array}{l}\text { FERC } \\
\text { Action }\end{array}$} & \multirow[b]{2}{*}{$\begin{array}{l}\text { Facility } \\
\text { Name }\end{array}$} & \multirow[b]{2}{*}{ State } & \multirow[b]{2}{*}{$\begin{array}{l}\text { Reservoir } \\
\text { Type }\end{array}$} & \multicolumn{3}{|c|}{ Capacity } \\
\hline & & & & & & $\begin{array}{l}\text { Working } \\
\text { Gas (Bct) }\end{array}$ & $\begin{array}{l}\text { Injection } \\
\text { (MMcf/d) }\end{array}$ & $\begin{array}{l}\text { Withdrawal } \\
\text { (MMcf/d) }\end{array}$ \\
\hline \multicolumn{9}{|l|}{ Approved } \\
\hline $\begin{array}{l}\text { Richfield Gas Storage } \\
\text { (CP92-285) }\end{array}$ & $1-7-92$ & $6-16-92$ & $\begin{array}{l}\text { Richfield } \\
\text { West Field }\end{array}$ & KS & $\begin{array}{l}\text { Depleted } \\
\text { Field }\end{array}$ & 3.5 & 22.9 & 43.6 \\
\hline $\begin{array}{l}\text { Transok }^{\mathrm{a}} \\
\text { (PR93-02) }^{\text {(PRO }}\end{array}$ & $10-16-92$ & $7-20-93$ & Greasy Creek & OK & $\begin{array}{l}\text { Depleted } \\
\text { Field }\end{array}$ & 13.2 & 130.0 & 225.0 \\
\hline $\begin{array}{l}\text { Petal Gas Storage } \\
\text { (CP93-69) }\end{array}$ & $11-18-92$ & $9-4-93$ & $\begin{array}{c}\text { Petal } \\
\text { (Chevron) }\end{array}$ & MS & Salt Cav & 3.5 & 160.0 & 320.0 \\
\hline $\begin{array}{l}\text { Koch Gateway } \\
\text { Pipeline }^{b} \text { (RP93-205) }\end{array}$ & $9-30-93$ & $3-31-94$ & Bistineau & LA & $\begin{array}{l}\text { Depleted } \\
\text { Field }\end{array}$ & 42.5 & NA & 430.0 \\
\hline $\begin{array}{l}\text { Bay Gas Storage } \\
\text { (PR94-01) }\end{array}$ & $10-12-93$ & $3-25-94$ & $\begin{array}{l}\text { S. AL- } \\
\text { Mclntosh }\end{array}$ & $\mathrm{AL}$ & Salt Cav & 1.5 & 6.0 & 17.5 \\
\hline $\begin{array}{l}\text { Ouachita River Gas } \\
\text { (CP94-38) }\end{array}$ & $10-21-93$ & $9-30-94$ & $\begin{array}{l}\text { Ouachita } \\
\text { River }\end{array}$ & LA & $\begin{array}{l}\text { Depleted } \\
\text { Field }\end{array}$ & 27.0 & 250.0 & 550.0 \\
\hline $\begin{array}{l}\text { Avoca Natural Gas } \\
\text { Storage (CP94-161) }\end{array}$ & $12-23-93$ & $7-7-94$ & $\begin{array}{c}\text { Avoca } \\
\text { (Phases 1-3) }\end{array}$ & NY & Salt Cav & 5.0 & 250.0 & 500.0 \\
\hline Total & - & - & - & - & - & 96.2 & - & $2,086.1$ \\
\hline \multicolumn{9}{|l|}{ Not Approved } \\
\hline $\begin{array}{l}\text { ANR Pipeline } \\
\text { (RP94-43) }\end{array}$ & $11-1-93$ & $5-2-94$ & Various & MI & $\begin{array}{l}\text { Depleted } \\
\text { Field }\end{array}$ & NA & NA & NA \\
\hline $\begin{array}{l}\text { Cove Point LNG } \\
\text { (CP94-59) }\end{array}$ & $11-3-93$ & $9-28-94$ & Cove Point & MD & LNG & 2.4 & 15.0 & 400.0 \\
\hline $\begin{array}{l}\text { Michigan Consolidated } \\
\text { Gas (PR94-09) }\end{array}$ & $3-2-94$ & $7-19-94$ & Various & MI & $\begin{array}{l}\text { Depleted } \\
\text { Field }\end{array}$ & 141.6 & NA & $3,151.0$ \\
\hline Total & - & - & - & - & - & - & - & - \\
\hline \multicolumn{9}{|l|}{ Pending } \\
\hline $\begin{array}{l}\text { Enron } \\
\text { (PR94-02) }\end{array}$ & $11-15-93$ & - & Napoleonville & LA & Salt Cav & 4.6 & 200.0 & 400.0 \\
\hline $\begin{array}{l}\text { Entre Energy } \\
\text { (CP94-389) }\end{array}$ & $4-28-94$ & - & $\begin{array}{c}\text { Chandeleur } \\
29\end{array}$ & LA & $\begin{array}{l}\text { Depleted } \\
\text { Field }\end{array}$ & 26.0 & 300.0 & 300.0 \\
\hline $\begin{array}{l}\text { Llano, Inc. } \\
\text { (PR94-21) }\end{array}$ & $9-28-94$ & - & Grama Ridge & NM & $\begin{array}{l}\text { Depleted } \\
\text { Field }\end{array}$ & 14.5 & NA & 75.0 \\
\hline Total & - & - & - & - & - & 45.1 & - & 775.0 \\
\hline
\end{tabular}

${ }^{a}$ FERC granted initial approval for 4.0 Bcf to be made available as interstate storage services at market-based rates. The remainder is retained for intrastate storage services but may be made available in the future to interstate markets at market-based rates, subject to FERC review and approval.

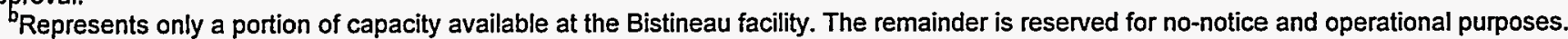
'Represents only a portion of capacity. The remainder is retained for intrastate service.

${ }^{\text {dPreliminary authorization only. }}$

In a Section 4 rate filing, ANR proposed a 2-year pilot program utilizing market-based pricing for unspecified "new storage services." Capacities proposed for these services were not enumerated.

$\mathrm{Bcf}=$ Billion cubic feet. MMcf/d = Million cubic feet per day. NA = Not available. $L N G=$ Liquefied natural gas.

Source: Federal Energy Regulatory Commission, as of January 20, 1995. 
In general, if an applicant's market analysis is: (1) based on a geographic and product-alternative definition of the market acceptable to FERC, and (2) produces low market share and $\mathrm{HHI}$, the applicant's chances for approval are excellent. On the other hand, relatively large market share and/or high $\mathrm{HHI}$ is/are not necessarily "fatal" to the application. FERC has pointed out that it would consider a number of other competitive factors in determining whether or not an applicant could have market power, such as excess capacity in the market, ease of entry by other competitors and/or impending entry by other competitors, and the presence of large and sophisticated buyers in the market. For example, sophisticated buyers are capable of purchasing storage service from that market where the price or quality of service is most competitive.

\section{Market Power: Some Guiding Principles from FERC}

Several important points have emerged from the cases that FERC has considered to date. For example, in the case where FERC denied market-based rates for Cove Point LNG (CPL), the company's business affiliations were a key factor both in evaluating market share and $\mathrm{HHI}$, as well as in assessing the potential for deals with customers that might be negotiated at less than "arm's length." CPL had proposed to provide "winter peaking" services in 3-, 5-, and 10-day arrangements at negotiated, market-based rates. CPL is a limited partnership whose general partners are affiliated with Columbia Gas System, Inc., and the Potomac Electric Power Co. (PEPCO). At the same time, PEPCO is also identified as a potential customer of CPL.

One concern expressed by FERC was the potential for a customer of CPL, which also happens to be a regulated affiliate, to pay "negotiated" but higher-than-competitive rates for storage service, then pass along these higher rates to their captive customers downstream. Further, in reviewing the market analysis offered by CPL, FERC established the principle that it will treat affiliated companies selling the same or substitute products as being a single seller. Thus, all of the underground storage facilities and LPG facilities of the Columbia Gas System that would be suitable for similar peaking services as proposed by CPL were added to CPL's capacities for purposes of the market share and $\mathrm{HHI}$ computations.

\section{Outlook for Market-Based Rates}

It is easier for relatively small, individual facilities with few or no affiliations to justify market-based rates, especially those serving market areas that already have plenty of good storage alternatives available. Demonstration of lack of market power may be even easier for new entrants, because they essentially start with no market share and therefore must offer customers a better deal than what is currently available in the market. To date, most of the applications have come from independent companies with facilities in producing areas. These areas, in addition to having numerous natural gas producers, have more pipelines and storage operators than do consuming areas. Thus, it is possible that market entry for a new storage operator is easier in producing areas because access to more pipelines provides access to more potential customers, and because it is less likely that one or a few storage providers dominate the market.

Market-based rates from existing storage providers in market or consuming areas will probably be harder to justify, because in many instances much or most of the existing storage capacity is owned or controlled by only a few storage operators, oftentimes the few major pipeline suppliers for these areas. Market-based rates for storage services from new entrants in consuming areas are certainly feasible; in fact two have been approved to date. In addition, there are a number of planned projects in consuming areas that could qualify. As these projects proceed, it is expected that some will generate additional applications for market-based rates.

As already stated, FERC has yet to approve market-based rates on a company-wide basis. However, to date only two companies have requested such broad authority: Michigan Consolidated Gas (MichCon) and ANR Pipeline Company. ${ }^{37}$ Neither presented any market power analysis. MichCon relied on the Michigan Public Service Commission's earlier approval of market-based rates for its intrastate storage services. ANR included its request for market-based rates in a recent rate filing.

To gain company-wide market-based rates for storage, large pipeline companies will have to argue convincingly that industry restructuring and "interconnectedness" have effectively broadened the market for storage beyond some narrow geographic area where that company predominates, and that prospective storage customers in actuality have many good alternatives. Alternatively, or perhaps in conjunction with this argument, the company could argue that the secondary or capacity release market is a guarantee against the accumulation or exercise of market power.

\footnotetext{
${ }^{77} A N R$ Pipeline is an interstate pipeline company subject to the jurisdiction of FERC. It owns and operates 14 underground storage facilities, all of which are in Michigan. Its storage fields have a total working gas capacity of approximately $189 \mathrm{Bcf}$, and daily deliverability of more than 3.4 Bef per day. Altogether, 11 companies operate storage fields in Michigan. with aggregate working gas capacity of about $617 \mathrm{Bcf}$ and deliverability of about 11.2 Bef per day. (ANR Pipeline and ANR Storage are different and unrelated companies.)
} 
Some believe that this "capacity release" argument will eventually be used by large storage providers to attempt to justify market-based rates, and that its success will probably parallel whatever success the corollary argument for marketbased transportation rates has with FERC. Currently, Transcontinental Gas Pipeline Company has a case pending before FERC that requests market-based transportation rates for its system. The company uses the argument that the competitive force of transportation capacity release is sufficient to preclude market power. FERC has delayed hearings on the case until it has at least 12-months' experience with transportation capacity release to assess its impact and effectiveness.

\section{Storage Capacity Release}

As with transportation capacity, FERC requires that interstate storage providers allow their customers to release unused storage capacity. FERC also requires storage providers to facilitate release transactions by posting available capacity on their electronic bulletin boards (EBB's). ${ }^{38}$ Since Order 636 went into effect on November 1, 1993, however, storage capacity release activity has been quite limited. Capacity release has taken place in the storage facilities of only a few storage providers.

The storage capacity release market is referred to as a secondary market. The primary market comprises a set of contracts between storage service providers and their customers. Such contracts give the customer, such as a distribution company, the right to store gas in a storage facility. Thus, the distribution company has rented some unidentified portion of space within a storage site for storing gas that it owns. The release market is used to sublet this space.

One reason for the lack of activity in the release market is simply that the concept and practice of unbundled storage services is so new in the industry. Before Order 636, few shippers had any experience in buying unbundled storage services, and the concept of capacity release, much less a market for released capacity, was nonexistent. It seems likely that shippers, having just contracted for storage services separately for the first time, are being conservative, even cautious, about releasing capacity until they have more experience in using and managing their capacity.

\footnotetext{
${ }^{34}$ Under Order 636, FERC requires pipeline companies to adminster a capacity release program for its system by providing electronic bulletin boards where capacity offers are posted, bids are evaluated, and winning bids are determined. See Energy Information Administration, Natural Gas 1994: Issues and Trends, DOE/EIA-0560(94) (Washington, DC, July 1994), p. 45.
}

Another reason for this lack of activity may be that current rate structures and rate design guidelines for the major renters of storage capacity-local distribution companies-provide few incentives for them to pursue storage capacity release. State public utility commissions (PUC's) may reevaluate these regulations and require LDC's to itemize and separately charge for storage services provided for customers. If a PUC is persuaded that LDC's are purchasing too much storage capacity, it could also disallow the associated costs from the rate base. At least one State is experimenting with providing incentives for LDC's to utilize the secondary market to cut costs. In North Carolina, an LDC is permitted to keep as profit 10 percent of the revenues received from marketing released storage capacity. If experiments of this type prove successful, other States are likely to follow suit, which would probably expand the storage release market. ${ }^{39}$

A third reason for the lack of activity could be that firm storage capacity is being rebundled and sold with the unregulated natural gas commodity and possibly firm transportation service instead of being released through pipeline company-operated EBB's. Some of these transactions are devised under arrangements known as "buy-sell" agreements. ${ }^{40}$ Many of these transactions do not have to be done through EBB's in that all buy-sell agreements made before November 1, 1993, were "grandfathered" by Order 636 as being exempt from the capacity release program.

The use of arrangements that are not posted on the EBB's, such as those under buy-sell agreements under Order 636, has been labeled the "gray market" for capacity." Several reasons exist why shippers might prefer to trade unneeded storage capacity through the gray market instead of through the capacity release program: (1) to avoid using cumbersome EBB's, (2) to preselect trading partner(s), (3) to earn higher margins by creating a value-added product and by limiting price discovery, and (4) to speed up the transaction by avoiding the competitive bidding process.

Despite the shortcomings of the capacity release market and its small size, available data give some indication of the market's potential. First, the capacity release market allows a buyer to enter into short-term agreements for storage capacity

\footnotetext{
3"Jeff D. Makholm, "Gas Pipeline Capacity," Public Utilities Fortnightly (October 1, 1994), p. 20.

${ }^{\text {st }}$ There are several types of buy-sell agreements. Many permit shippers to sell a rebundled package of firm storage capacity or firm transportation capacity along with the natural gas commodity to an end user. For example, under one type of buy-sell agreement, the shipper or LDC will purchase gas on behalf of an end user, then transport or store the gas for the end user under the firm rights the shipper had purchased from an interstate pipeline company.

${ }^{4}$ Philip M. Marston, "The Rumble of Bundles: A Review of Experience Under the Capacity Release Experiment" (Hadson Gas Systems, Inc., August 1994).
} 
rights. For example, several releases of capacity have been for less than 14 days. (Posted daily rates for these short-term releases have been $\$ 0.0329$ per thousand cubic feet or even lower. ${ }^{42}$ Second, capacity releases can be large. Several capacity releases have been for several years and have involved more than a billion cubic feet of capacity. Third, sellers of capacity may discount the cost of storage capacity. Holders of unutilized storage capacity have an economic incentive to sell this unused capacity. As the return from unused capacity is zero, any rate received represents income that would not have been received otherwise. Using information available from pipeline company EBB's, marketers will increasingly canvass holders of storage capacity to see if they want to release any unused capacity. If the capacity release market follows the path of the transportation capacity release market, sellers of capacity rights will continue to discount the cost of capacity. As discounting becomes common, the size of the market should grow.

Growth of the capacity release market is important for several reasons. If a large percentage of owners of capacity rights enter the market when they have more than they need, the market will provide information on where excess capacity exists. When the cost of storage service is known in terms of the additional cost of delivered gas per million Btu, buyers of storage service will be better equipped to compare the cost of underground storage service to other means of obtaining peaking service. In addition, when the cost of storage is known, buyers will have incentives to practice efficient behavior in the utilization of storage. When cost information is available for different regions, buyers will be able to factor in transportation rates and may be able to use more of the storage in regions where the storage is relatively cheap and less in regions where the storage is expensive.
As storage capacity is used more and more efficiently, the price charged for storage rights will indicate whether or not the value of storage is great enough to support additional investment in storage. Thus, some of the currently planned storage projects may be canceled because they will be unable to be price competitive. This result has already been observed in the transportation market, where various planned pipeline construction projects have not survived because of the effects of open access. A similar result can be expected in the area of storage capacity.

\section{Summary}

Trends toward customer ownership of working gas and greater emphasis on inventory management are expected to continue under Order 636. New market requirements are driving the addition of new underground storage facilities and the performance characteristics of these facilities, such as high deliverability rates and the ability to withdraw and inject gas year round with little or no notice. Salt cavern storage has become a more important source for meeting customers' peak demands, even though there is a limited volume of working gas and the cycling potential has yet to be fully exploited.

The newest trends in underground storage are in market-based rates and capacity release, the latter being a direct consequence of Order 636. Experience is limited in both areas, but both have the potential to make natural gas storage a more useful and efficient tool for meeting the needs of the gas consumer.

${ }^{42}$ The posted rate may not include all costs. 
Appendix A

\section{Underground Natural Gas Storage Operations}





\section{Appendix A}

\section{Underground Natural Gas Storage Operations}

This appendix presents a brief perspective on various types of underground natural gas storage operations in the United States today. It includes a discussion of the types of companies that own storage, the types of facilities used in storage operations, the characteristics of each, and how each type is integrated into daily operations of mainline and local distribution systems. It also includes a brief discussion of alternative natural gas storage mediums such as liquefied natural gas and propane-air facilities, which are used to meet temporary demand spikes for natural gas service. ${ }^{43}$

\section{Overview}

Underground storage, in common usage, is gas transferred from the reservoir of discovery to other reservoirs, usually closer to market areas, where it is stored until needed to meet market demand. Natural gas is stored in underground reservoirs (Figure A1) primarily to ensure the capability of the gas industry to meet seasonal fluctuations in demand. Underground storage supplements the industry's production and delivery systems, allowing supply reliability during periods of heavy gas demand by residential and commercial consumers for space heating. Storage is also used occasionally as a conservation measure to prevent flaring and other waste when production rates exceed marketability.

The three principal types of underground storage sites used in the United States today are: (1) depleted reservoirs in oil and/or gas fields, (2) aquifers, and (3) salt cavern formations. Each type has its own physical characteristics (porosity, permeability, retention capability) and economics (site preparation costs, deliverability rates, cycling capability), which governs its suitability to particular applications.

The most important characteristic of an underground storage reservoir is its capability to hold natural gas for future

\footnotetext{
${ }^{43}$ For detailed engineering and technical information regarding underground storage of natural gas, see Gas Engineers Handbook: Fuel Gas Engineering Practices (New York: Industrial Press Inc., 1974); and Donald L. Katz and others, Handbook of Natural Gas Engineering (New York: McGraw-Hill Book Company). For general historical information on the early gas storage industry, see American Gas Association, Inc., The Underground Storage of Gas in the United States and Canada, 19th Annual Report on Statistics, X54170 (December 31, 1969).
}

delivery. The measure of this is called working gas capacity: the amount of natural gas inventory that can be withdrawn to serve customer needs. In addition to working (top storage) gas, underground storage reservoirs also contain base (cushion) gas and, in the case of depleted oil and/or gas field reservoirs, native gas. Native gas is the gas that remains after economic production ceases and before conversion to use as a storage site. Upon development of a storage site, additional gas is injected and combined with any existing native gas in order to develop and maintain adequate storage reservoir pressure to meet required deliverability rates. The resulting (permanent) inventory is referred to as the base or cushion load. During heavy demand periods, some base gas may be withdrawn temporarily and delivered as working gas, but over the long term, base levels must be maintained to ensure operational capability.

Relatively small quantities of gas are stored as liquefied natural gas (LNG) in specially constructed insulated containers, and small volumes of compressed gas are stored in tanks commonly referred to as gas holders. For short periods the pipes themselves are used for storage by compressing more gas into the same space; this is called line packing. Peak demands (peaking service) are also met by synthetic gas or propane and other natural gas liquids.

In 1915, natural gas was first successfully stored underground in Welland County, Ontario, Canada. Several wells in a partially depleted gas field were reconditioned. Subsequently, gas was injected into the reservoir and withdrawn the following winter. In the United States, in 1916, Iroquois Gas Company placed the Zoar field, south of Buffalo, New York, into operation as a storage site. In 1919, the Central Kentucky Natural Gas Company repressured the depleted Menifee gas field in Kentucky. By 1930, nine storage pools in six different States were in operation with a total capacity of about 18 billion cubic feet. Before 1950 , essentially all gas storage was in partially or fully depleted gas reservoirs.

In some areas of the country, particularly the Midwest, suitable depleted gas/oil fields were unavailable for potential conversion to storage fields. As a result, the concept of using an aquifer formation for storage was tested and developed. Although the testing was done in the 1930's, it was not until the early 1950's that attention was turned to the use of aquifers for storing natural gas. 
Figure A1. Illustration of the Various Types of Underground Storage

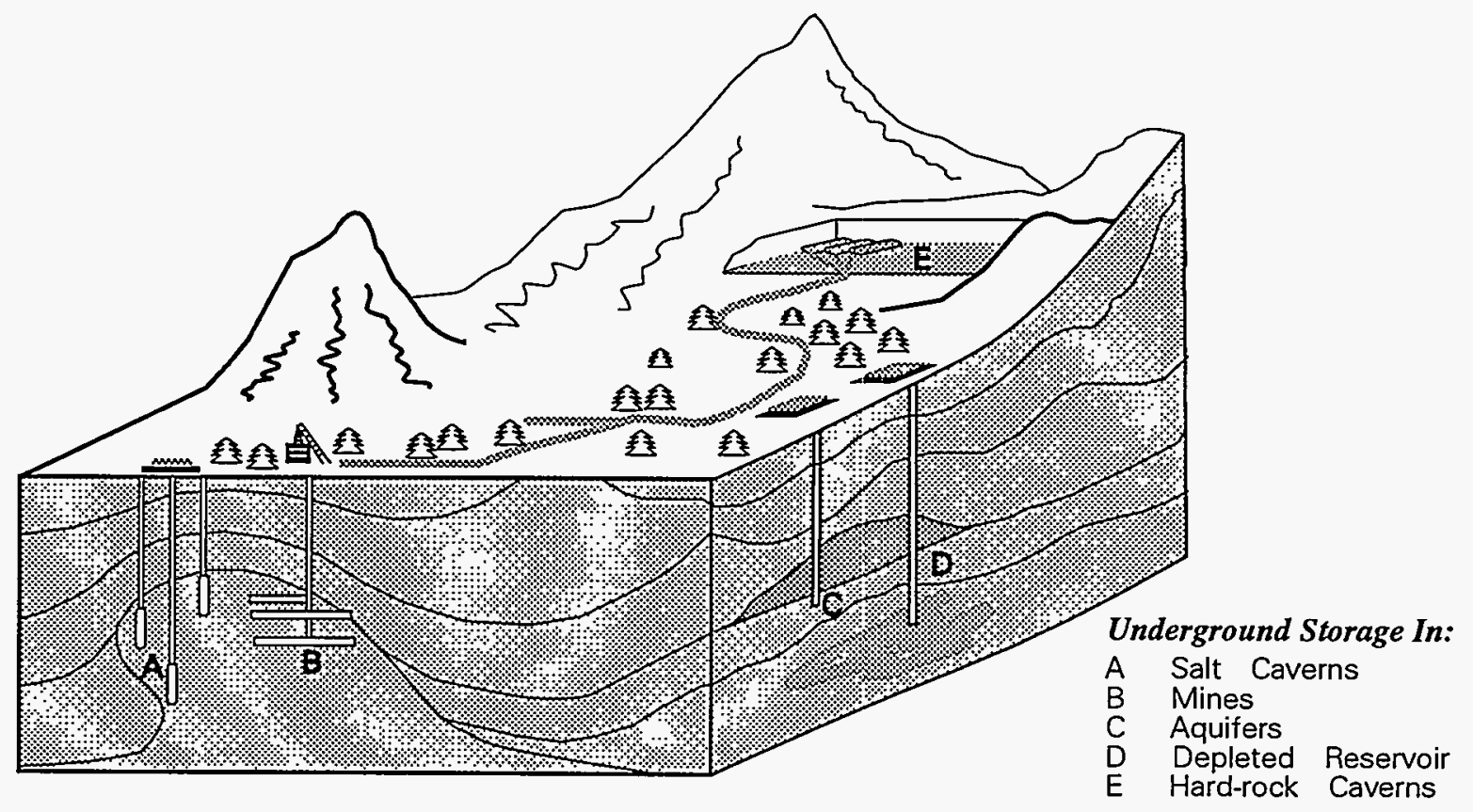

Source: PB-KBB Inc., "Underground Storage and Subsurface Systems": Recreated by Energy Information Administration, Office of Planning, Management, and Information Services.

Most of the Nation's storage sites were developed between 1955 and the early 1980 's. During this period, U.S. storage capacity increased over fourfold, from about 2.1 trillion cubic feet (Tcf) in 1955 to $8 \mathrm{Tcf}$ in $1985 .{ }^{44}$ The need for underground storage grew as consumption of natural gas increased significantly. The mix and requirements of consumers also changed as demand shifted toward the more weather-sensitive residential and commercial markets. Furthermore, in the mid- and late-1970's, the interstate market encountered supply and demand imbalance situations during several exceptionally cold winters, and as a result service curtailments were imposed.

The sporadic inability of the industry during the winter months to meet large and sudden increases in demand for natural gas in some areas helped stimulate the planning and construction of new storage. Increased storage development was seen by regulators and industry alike as necessary to avoid a repeat of such occurrences and also to satisfy expected increases in gas demand during the 1980's.
Since the mid-1980's, total storage capacity has remained at approximately $8 \mathrm{Tcf}$, even with the recent surge in new storage development. (Some new sites have been added but some have also been abandoned.) However, the daily deliverability from storage has increased. The volatile gas market during the late 1980's set in motion certain events that heightened interest in new storage facility development. Interest in new storage resurged as regulatory changes under Federal Energy Regulatory Commission (FERC) Orders 436 and 636 forced more competition into the marketplace. Storage became increasingly important as all pipeline services were unbundled and customers had to make their own storage arrangements. These changes led to increased interest in development of storage sites that would provide greater deliverability and more access to working gas capacity. Between 1992 and 1994, deliverability from storage increased by 5 percent, from approximately $65 \mathrm{Bcf}$ per day ${ }^{45}$ to $68 \mathrm{Bcf}$ per day (Table A1).

\footnotetext{
"American Gas Association, Gas Facts: 1979 Data (Arlington, VA, 1979); and Energy Information Administration, Natural Gas Monthly, February 1991, DOE/EIA-0130(91/02) (Washington, DC, February 1991).
}

\footnotetext{
${ }^{45}$ Energy Information Administration, Natural Gas 1992: Issues and Trends, DOE/EIA-0560(92) (Washington, DC, March 1993), Table 12, p. 87.
} 
Table A1. Summary of Existing Underground Natural Gas Storage, by State and Type of Reservoir, 1993

\begin{tabular}{|c|c|c|c|c|c|c|c|c|c|c|c|c|}
\hline \multirow[b]{2}{*}{ State } & \multicolumn{3}{|c|}{ Depleted Gas/Oil } & \multicolumn{3}{|c|}{ Aquifer Storage } & \multicolumn{3}{|c|}{ Salt Cavern Storage } & \multicolumn{3}{|c|}{ Total } \\
\hline & $\begin{array}{c}\text { Number } \\
\text { of } \\
\text { Sites }\end{array}$ & $\begin{array}{c}\text { Working } \\
\text { Gas } \\
\text { Capacity } \\
\text { (Bcf) }\end{array}$ & $\begin{array}{c}\text { Daily } \\
\text { Deliver- } \\
\text { ability } \\
\text { (MMcf/day) }\end{array}$ & $\begin{array}{c}\text { Number } \\
\text { of } \\
\text { Sites }\end{array}$ & $\begin{array}{c}\text { Working } \\
\text { Gas } \\
\text { Capacity } \\
\text { (Bcf) }\end{array}$ & $\begin{array}{c}\text { Daily } \\
\text { Deliver- } \\
\text { ability } \\
\text { (MMcf/day) }\end{array}$ & $\begin{array}{c}\text { Number } \\
\text { of } \\
\text { Sites }\end{array}$ & $\begin{array}{c}\text { Working } \\
\text { Gas } \\
\text { Capacity } \\
\text { (Bcf) }\end{array}$ & $\begin{array}{c}\text { Daily } \\
\text { Deliver- } \\
\text { ability } \\
\text { (MMcf/day) }\end{array}$ & $\begin{array}{c}\text { Number } \\
\text { of } \\
\text { Sites }\end{array}$ & $\begin{array}{c}\text { Working } \\
\text { Gas } \\
\text { Capacity } \\
\text { (Bcf) }\end{array}$ & $\begin{array}{c}\text { Daily } \\
\text { Deliver- } \\
\text { ability } \\
\text { (MMcf/day) }\end{array}$ \\
\hline Arkansas & 1 & 3 & 32 & 0 & 0 & 0 & 0 & 0 & 0 & 1 & 3 & 32 \\
\hline California & 9 & 222 & 5,618 & 0 & 0 & 0 & 0 & 0 & 0 & 9 & 222 & 5,618 \\
\hline Colorado & 9 & 57 & 926 & 0 & 0 & 0 & 0 & 0 & 0 & 9 & 57 & 926 \\
\hline lowa & 0 & 0 & 0 & 4 & 98 & 965 & 0 & 0 & 0 & 4 & 98 & 965 \\
\hline Illinois & 10 & 41 & 679 & 17 & 277 & 4,849 & 0 & 0 & 0 & 27 & 317 & 5,529 \\
\hline Indiana & 16 & 18 & 268 & 8 & 17 & 280 & 0 & 0 & 0 & 24 & 35 & 549 \\
\hline Kansas & 18 & 118 & 2,215 & 0 & 0 & 0 & 1 & 2 & 100 & 19 & 120 & 2,315 \\
\hline Kentucky & 19 & 99 & 2,847 & 2 & 6 & 106 & 0 & 0 & 0 & 21 & 105 & 2,953 \\
\hline Louisiana & 8 & 273 & 4,049 & 0 & 0 & 0 & 3 & 12 & 944 & 11 & 285 & 4,993 \\
\hline Maryland & 1 & 16 & 306 & 0 & 0 & 0 & 0 & 0 & 0 & 1 & 16 & 306 \\
\hline Michigan & 44 & 615 & 11,101 & 0 & 0 & 0 & 2 & 3 & 80 & 46 & 617 & 11,181 \\
\hline Minnesota & 0 & 0 & 0 & 1 & 2 & 60 & 0 & 0 & 0 & 1 & 2 & 60 \\
\hline Missouri & 0 & 0 & 0 & 1 & 8 & 350 & 0 & 0 & 0 & 1 & 8 & 350 \\
\hline Mississippi & 3 & 35 & 1,025 & 0 & 0 & 0 & 3 & 17 & 1,020 & 6 & 52 & 2,045 \\
\hline Montana & 4 & 203 & 308 & 0 & 0 & 0 & 0 & 0 & 0 & 4 & 203 & 308 \\
\hline Nebraska & 2 & 15 & 221 & 0 & 0 & 0 & 0 & 0 & 0 & 2 & 15 & 221 \\
\hline New Mexico & 2 & 58 & 325 & 1 & 6 & 14 & 0 & 0 & 0 & 3 & 64 & 339 \\
\hline New York & 21 & 75 & 1,009 & 0 & 0 & 0 & 0 & 0 & 0 & 21 & 75 & 1,009 \\
\hline Ohio & 22 & 238 & 4,653 & 0 & 0 & 0 & 0 & 0 & 0 & 22 & 238 & 4,653 \\
\hline Oklahoma & 12 & 133 & 5,468 & 0 & 0 & 0 & 0 & 0 & 0 & 12 & 133 & 5,468 \\
\hline Oregon & 1 & 7 & 80 & 0 & 0 & 0 & 0 & 0 & 0 & 1 & 7 & 80 \\
\hline Pennsylvania & 55 & 329 & 4,736 & 0 & 0 & 0 & 0 & 0 & 0 & 55 & 329 & 4,736 \\
\hline Texas & 18 & 321 & 4,239 & 0 & 0 & 0 & 12 & 48 & 4,897 & 30 & 369 & 9,136 \\
\hline Utah & 1 & 45 & 400 & 2 & 9 & 98 & 0 & 0 & 0 & 3 & 54 & 498 \\
\hline Washington & 0 & 0 & 0 & 1 & 15 & 525 & 0 & 0 & 0 & 1 & 15 & 525 \\
\hline West Virginia & 35 & 209 & 2,722 & 0 & 0 & 0 & 0 & 0 & 0 & 35 & 209 & 2,722 \\
\hline Wyoming & 5 & 42 & 147 & 1 & 4 & 58 & 0 & 0 & 0 & 6 & 46 & 205 \\
\hline Total & 316 & 3,170 & 53,380 & 38 & 443 & 7,306 & 21 & 82 & 7,041 & 375 & 3,695 & 67,729 \\
\hline
\end{tabular}

Bcf $=$ Billion cubic feet. MMcf/day $=$ Million cubic feet per day.

Note: Does not include 21 storage facilities reported on Form EIA-191 because they are considered inactive or standby for purposes of this report.

Source: Energy Information Administration, EIA-191, "Underground Gas Storage Report."

\section{Owners and Operators of Storage}

The principal owner/operators of these underground storage facilities are (1) interstate pipeline companies, (2) local distribution companies (LDC's), (3) intrastate pipeline companies, and (4) independent storage service providers. Several natural gas producers and large industrial users also own a limited amount of storage.

Interstate pipeline companies operate about 62 percent of all working gas capacity in the United States (Table A2). Historically, these FERC-jurisdictional companies have owned and distributed most of the natural gas from U.S. underground storage sites. Underground storage has traditionally been important to interstate pipeline companies because they depend heavily on storage inventories to facilitate load balancing and system supply management on their long-haul transmission lines.

LDC's and intrastate pipeline companies account for about 34 percent of working gas capacity. LDC's generally use gas from storage sites to serve customer needs directly, whereas intrastate pipeline companies use underground storage for operational balancing and system supply as well as the energy needs of end-use customers. While most LDC and intrastate pipeline storage operations are subject only to State regulatory agencies, 14 percent ( 8 of 58 ) are subject to FERC jurisdiction because they also provide significant service to the interstate market.

Independent operators own or operate about 4 percent of current working gas capacity. Many of the salt formation and 
Table A2. Summary of Existing Underground Natural Gas Storage, by Type of Ownership and Jurisdiction, 1993

\begin{tabular}{|c|c|c|c|c|c|c|c|c|c|c|c|c|}
\hline \multirow[b]{2}{*}{ State } & \multicolumn{3}{|c|}{ Depleted Gas/Oil } & \multicolumn{3}{|c|}{ Aquifer Storage } & \multicolumn{3}{|c|}{ Salt Cavern Storage } & \multicolumn{3}{|c|}{ Total } \\
\hline & $\begin{array}{c}\text { Number } \\
\text { of } \\
\text { Sites }\end{array}$ & $\begin{array}{c}\text { Working } \\
\text { Gas } \\
\text { Capacity } \\
\text { (Bcf) }\end{array}$ & $\begin{array}{c}\text { Daily } \\
\text { Deliver- } \\
\text { ability } \\
\text { (MMcf/day) }\end{array}$ & $\begin{array}{c}\text { Number } \\
\text { of } \\
\text { Sites }\end{array}$ & $\begin{array}{c}\text { Working } \\
\text { Gas } \\
\text { Capacity } \\
\text { (Bcf) }\end{array}$ & $\begin{array}{c}\text { Daily } \\
\text { Deliver- } \\
\text { ability } \\
\text { (MMcf/day) }\end{array}$ & $\begin{array}{c}\text { Number } \\
\text { of } \\
\text { Sites }\end{array}$ & $\begin{array}{c}\text { Working } \\
\text { Gas } \\
\text { Capacity } \\
\text { (Bcf) }\end{array}$ & $\begin{array}{c}\text { Daily } \\
\text { Deliver- } \\
\text { ability } \\
\text { (MMcf/day) }\end{array}$ & $\begin{array}{c}\text { Number } \\
\text { of } \\
\text { Sites }\end{array}$ & $\begin{array}{c}\text { Working } \\
\text { Gas } \\
\text { Capacity } \\
\text { (Bcf) }\end{array}$ & $\begin{array}{c}\text { Daily } \\
\text { Deliver- } \\
\text { ability } \\
\text { (MMcf/day) }\end{array}$ \\
\hline \multicolumn{13}{|l|}{ Nonjurisdictional } \\
\hline $\begin{array}{l}\text { Independents } \\
\text { LDC } \\
\text { Intrastate } \\
\quad \text { Total }\end{array}$ & $\begin{array}{r}6 \\
99 \\
9 \\
114\end{array}$ & $\begin{array}{r}51 \\
567 \\
133 \\
750\end{array}$ & $\begin{array}{r}823 \\
13,924 \\
2,486 \\
17,233\end{array}$ & $\begin{array}{r}0 \\
24 \\
0 \\
24\end{array}$ & $\begin{array}{r}0 \\
263 \\
0 \\
263\end{array}$ & $\begin{array}{r}0 \\
4,298 \\
0 \\
4,298\end{array}$ & $\begin{array}{r}7 \\
5 \\
2 \\
14\end{array}$ & $\begin{array}{r}21 \\
19 \\
5 \\
44\end{array}$ & $\begin{array}{l}1,950 \\
1,224 \\
1,100 \\
4,274\end{array}$ & $\begin{array}{r}13 \\
128 \\
11 \\
152\end{array}$ & $\begin{array}{r}72 \\
849 \\
137 \\
1,058\end{array}$ & $\begin{array}{r}2,772 \\
19,446 \\
3,586 \\
25,805\end{array}$ \\
\hline \multicolumn{13}{|l|}{$\begin{array}{l}\text { Under FERC } \\
\text { Jurisdiction }\end{array}$} \\
\hline $\begin{array}{l}\text { Independents } \\
\text { Interstate } \\
\text { LDC } \\
\text { Total }\end{array}$ & $\begin{array}{r}9 \\
167 \\
26 \\
202\end{array}$ & $\begin{array}{r}197 \\
1,971 \\
251 \\
2,420\end{array}$ & $\begin{array}{r}1,629 \\
29,812 \\
4,707 \\
36,148\end{array}$ & $\begin{array}{r}0 \\
13 \\
1 \\
14\end{array}$ & $\begin{array}{r}0 \\
164 \\
15 \\
179\end{array}$ & $\begin{array}{r}0 \\
2,484 \\
525 \\
3,009\end{array}$ & $\begin{array}{l}2 \\
4 \\
1 \\
7\end{array}$ & $\begin{array}{r}6 \\
25 \\
7 \\
38\end{array}$ & $\begin{array}{r}375 \\
1,796 \\
597 \\
2,767\end{array}$ & $\begin{array}{r}11 \\
184 \\
28 \\
223\end{array}$ & $\begin{array}{r}203 \\
2,160 \\
274 \\
2,637\end{array}$ & $\begin{array}{r}2,004 \\
34,091 \\
5,828 \\
41,923\end{array}$ \\
\hline \multicolumn{13}{|l|}{ Total } \\
\hline $\begin{array}{l}\text { Independents } \\
\text { Interstate } \\
\text { LDC } \\
\text { Intrastate } \\
\quad \text { Total }\end{array}$ & $\begin{array}{r}15 \\
167 \\
125 \\
9 \\
316\end{array}$ & $\begin{array}{r}248 \\
1,971 \\
818 \\
133 \\
3,170\end{array}$ & $\begin{array}{r}2,451 \\
29,811 \\
18,630 \\
2,486 \\
53,380\end{array}$ & $\begin{array}{r}0 \\
13 \\
25 \\
0 \\
38\end{array}$ & $\begin{array}{r}0 \\
164 \\
279 \\
0 \\
443\end{array}$ & $\begin{array}{r}0 \\
2,483 \\
4,823 \\
0 \\
7,306\end{array}$ & $\begin{array}{r}9 \\
4 \\
6 \\
2 \\
21\end{array}$ & $\begin{array}{r}26 \\
25 \\
26 \\
5 \\
82\end{array}$ & $\begin{array}{l}2,325 \\
1,795 \\
1,820 \\
1,100 \\
7,041\end{array}$ & $\begin{array}{r}24 \\
184 \\
156 \\
11 \\
375\end{array}$ & $\begin{array}{r}275 \\
2,160 \\
1,123 \\
137 \\
3,695\end{array}$ & $\begin{array}{r}4,776 \\
34,091 \\
25,274 \\
3,586 \\
67,729\end{array}$ \\
\hline
\end{tabular}

Note: Bcf = Billion cubic feet; MMcf = Million cubic feet. Totals may not equal sum of components because of independent rounding. Source: Energy Information Administration, EIA-191, "Underground Gas Storage Report."

high-deliverability sites currently being developed have been initiated by independent storage service operators. If the independent operators principally serve the interstate market they are subject to FERC regulations; otherwise, they are State regulated. Several independent storage operations are joint ventures that include major interstate pipeline companies and LDC's as partners, or they are subsidiaries of interstate pipeline companies operating as independent entities.

\section{Types and Uses of Underground Storage}

Most existing gas storage in the United States is held in depleted natural gas or oil fields (Figure A2) located close to consumption centers. Conversion of a field from production to storage duty takes advantage of existing wells, gathering systems, and pipeline connections. The geology and producing characteristics of a depleted field are also well known. However, choices of storage field location and performance are limited by the inventory of depleted fields in any region.

In some areas, most notably the Midwestern United States, natural aquifers have been converted to gas storage reservoirs.
An aquifer is suitable for gas storage if the water-bearing sedimentary rock formation is overlaid with an impermeable cap rock. While the geology of aquifers is similar to depleted production fields, their use in gas storage usually requires more base (cushion) gas and greater monitoring of withdrawal and injection performance. Deliverability rates may be enhanced by the presence of an active water drive.

Salt caverns, the third main type of storage, provide very high withdrawal and injection rates compared with their working gas capacity. Base gas requirements are relatively low. The large majority of salt cavern storage facilities have been developed in salt dome formations located in the Gulf Coast States. Salt caverns leached from bedded salt formations in Northeastern, Midwestern, and Western States are also being developed to take advantage of the high volume and flexible operations possible with a cavern facility (see Appendix B). Cavern construction is more costly than depleted field conversions when measured on the basis of dollars per thousand cubic feet of working gas, but the ability to perform several withdrawal and injection cycles each year reduces the per-unit cost of each thousand cubic feet of gas injected and withdrawn.

Storage facilities may be classified as seasonal supply reservoirs (depleted gas/oil fields and aquifers for the most 


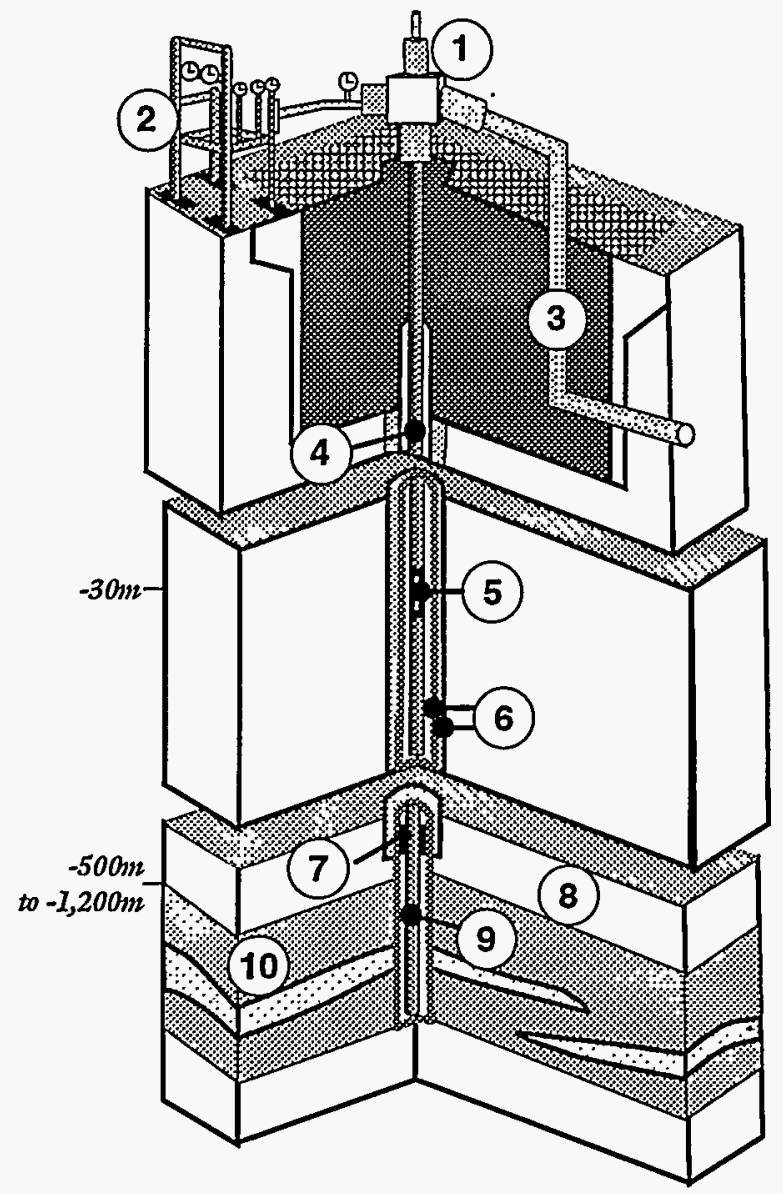

\author{
Cross Section of a \\ Storage Well: \\ 1. Wellhead. \\ 2. Safety Valve Control. \\ 3. Connection Pipe. \\ 4. Flow Tubing String. \\ 5. Automatic Safety Valve. \\ 6. Cemented Casing. \\ 7. Packer. \\ 8. Caprock. \\ 9. Strainers $(-500$ to $-1,200 \mathrm{~m})$. \\ 10. Reservoir.
}

Source: Gaz de France, "Underground Storages Facilities" (June 1992): Recreated by Energy Information Administration, Office of Planning, Management, and Information Services.

part) and high-deliverability sites (mostly salt cavern reservoirs). Seasonal supply sites are designed to be filled during the 214-day nonheating season (April through October) and drawn down during the 151-day heating season (November through March). High-deliverability sites are situated to provide a rapid drawdown (or rebuilding) of inventory to respond to such needs as volatile peaking demands, emergency backup, and/or system load balancing. Compared to seasonal storage, high-deliverability sites can be drawn down in 20 days or less and refilled in 40 days or less.

High deliverability can be achieved in a depleted oil or gas reservoir if the reservoir rock has high porosity and permeability (allowing a rapid flow of gas), and the reservoir has sufficient base gas pressure and a sufficient number of wells to maximize withdrawal. Additionally, it would be desirable to be able to refill a reservoir in a reasonably short time. Salt cavern storage is ideal for high deliverability, as the entire cavern is one large "pore." On average, salt storage facilities can withdraw their gas in 12 days, versus 71 days for aquifers and 64 days for all depleted oil or gas reservoirs. Newly introduced horizontal drilling techniques permit storage in older depleted gas/oil field storage fields to be retrofitted to increase deliverability.

\section{Depleted Gas or Oil Fields}

Underground storage in depleted gas/oil fields (Figure A2) is used when gas can be injected into reservoirs with suitable pore space, permeability, and retention characteristics. All oil and gas reservoirs share similar characteristics in that they are composed of rock with enough porosity so that hydrocarbons can accumulate in the pores in the rock, and they have a less permeable layer of rock above the hydrocarbon-bearing stratum. The hydrocarbon accumulation in the porous rock is pressurized by the weight of hundreds or thousands of feet of rock on top of the reservoir. When a well hole penetrates the impermeable cap layer of rock, the hydrocarbon under 
pressure is exposed to the much lower atmospheric pressure, and gas can flow into and out of the well.

Depleted oil and gas reservoirs are the most commonly used underground storage sites because of their wide availability. They use the pressure of the stored gas and, in some cases, water infiltration pressure to drive withdrawal operations. Cycling (number of times a year the total working gas volume may be injected/withdrawn per year) is relatively low, and daily deliverability rates are dependent on the degree of rock porosity and permeability, although the facilities are usually designed for one injection and withdrawal cycle per year. Daily deliverability rates from depleted fields vary widely because of differences in the surface facilities (such as compressors), base gas levels, and the fluid flow characteristics of each reservoir. Retention capability, which is the degree to which stored gas is held within the reservoir area, however, is highest of the three principal types of underground storage. Depleted field storage is also the least expensive to develop, operate, and maintain.

In order to use an abandoned gas reservoir for storage, one or more of the wells used for extraction are typically used to inject gas. As with extraction, the more porous the rock, the faster the rate of injection can be. As pressure builds up in the reservoir, the rate of injection slows down-pushing the gas in against higher pressure requires more force. Similarly, when the reservoir is at peak pressure, the rate of extraction is greater than at minimum pressure.

The factors that determine whether a gas reservoir will make a good storage reservoir are both geographic and geologic. The greater the porosity of the rock, the faster the rates of injection and withdrawal. In some cases, where the reservoir rock is "tight" or of low porosity, then some form of stimulation of the reservoir may also be performed. This would include various methods to introduce cracks into the reservoir rock, thus increasing the opportunities for the hydrocarbon to flow towards the well hole.

The size of the reservoir-the thickness of the gas-bearing rock stratum and the extent to which the stratum is covered by cap rock-is another factor. The location is also a factor-if the reservair is not close to existing trunk pipelines or market areas and distribution lines, then greater expense will be incurred to establish connecting pipelines.

\section{Aquifers}

An aquifer storage site (Figure A3) is a water-only reservoir conditioned to hold natural gas. Such sites are usually used as storage reservoirs only when depleted gas or oil reservoirs are not available. Aquifers have been developed exclusively in market areas. In general, aquifer storage is more expensive to develop and maintain than depleted gas or oil reservoir storage.

Today, aquifer storage accounts for only 11 percent of the total working gas capacity and daily deliverability in the United States. Most of the aquifer storage is located in the States of Illinois (18), Indiana (8), and Iowa (4). In fact, all of the underground storage sites in Iowa are aquifers. The remaining eight aquifer sites are scattered among five different States.

There are several reasons why an aquifer is the least desirable site for natural gas storage. First, it takes much longer to condition the site: on average about 4 years, which is twice as long as for an average depleted gas or oil field. Unlike a depleted site, the geology of an aquifer site is unknown beforehand. As a result, seismic testing must be performed to determine its geologic profile. Important also are such characteristics as the confinement area of the reservoir, the location and type of the "cap" rock ceiling barrier, existing reservoir pressure, and the porosity and permeability of the reservoir rock. The potential capacity of the reservoir is also unknown and can only be determined as the site is further developed.

Second, all new facilities must be installed, including wells, pipelines, dehydration facilities, and compressor operations. Aquifer storage sites may also require additional facilities such as greater compression for injection purposes (to push back the water), more extensive dehydration facilities (which are not always needed at gas reservoir sites), and "collector" wells drilled into formations above the cap rock, which recover gas that may penetrate out of the storage zone. An important consideration is that the design of the facilities specifically meet the peak-period needs of the customers expected to use the service. Because of the additional support of an aquifer's water (pressure) drive, in most instances, higher sustained deliverability rates than gas or oil reservoirs can be designed and incorporated at the site.

Third, no native gas is present in an aquifer formation. Thus, once initial testing has been completed and site development approval has been granted, base or cushion gas must be introduced into the reservoir to build and maintain deliverability pressure. While base gas in gas/oil storage reservoirs usually is about 50 percent of total capacity, base gas in aquifer storage may constitute as much as 80 to 90 percent by the time the site is fully developed for gas storage.

Needless to say, the need to acquire such large volumes of base gas to maintain operational integrity is a crucial component in assessing the economic viability of the overall project. Most, if not all, of this base gas is not recoverable (even when the site is abandoned). Many of the sites in 
Figure A3. Typical Configuration of Aquifer Storage

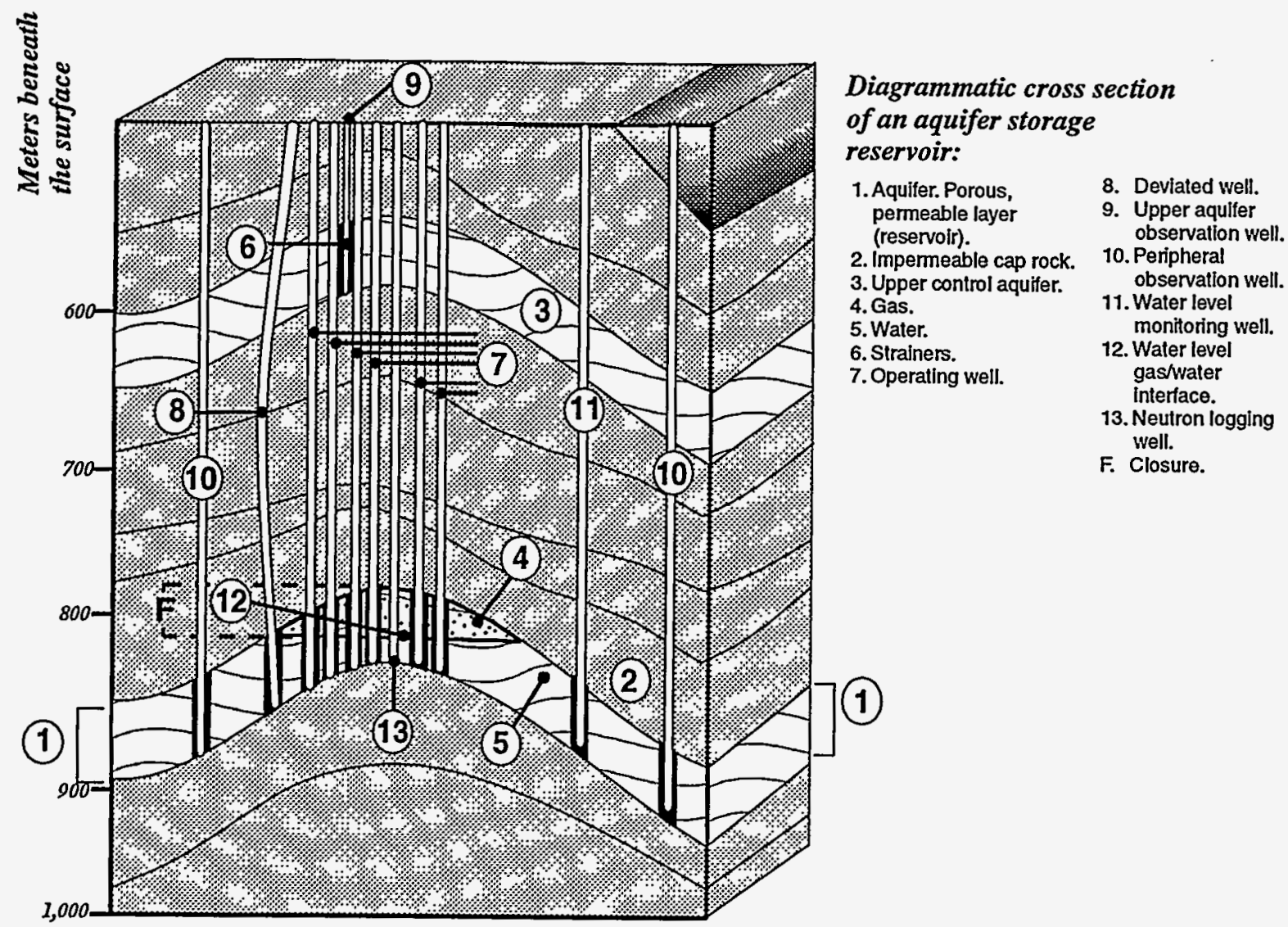

Source: Gaz de France, "Underground Storages Facilities" (June 1992): Recreated by Energy Information Administration, Office of Planning, Management, and Information Services.

operation today were developed when the market price for natural gas was very low. In today's market, developing aquifer storage can be a very expensive undertaking.

Aquifer storage deliverability during the heating season is designed around specific customer requirements. These requirements may be for deliveries over a set period of time, for instance, 20,60 , or 120 days. The overall facility design reflects these combined requirements. These requirements also delimit the degree of cycling, that is, the number of times total working levels may be depleted and replenished during a heating season, that may occur at an aquifer site. The sustained delivery rate cannot exceed design limits. Otherwise, unlike depleted oil and gas reservoir storage where cushion gas can be tapped when needed, tapping cushion gas in an aquifer storage site can have an adverse effect upon reservoir performance.

Lastly, and perhaps the most important constraint on the future use of aquifer formations for natural gas storage, is the environmental qualifier. In the early 1980's, the U.S. Environmental Protection Agency (EPA) issued regulations that tightly restrict the future development of aquifer storage in an effort to avoid further or potential contamination of available water supplies. A permit for aquifer storage will be issued only if the potential site has salinization levels that make the water unusable for drinking or most agricultural purposes. Additional restrictions also apply.

\section{Salt Formations}

Salt formations have several properties that make them ideal for storing natural gas. A salt cavern is virtually impermeable to gas and once formed, a salt reservoir's walls have the structural strength of steel. Thus, gas cannot easily escape the large hollowed-out shape that forms a salt storage cavern (Figure A4). 
Figure A4. Typical Configuration of Salt Dome Storage

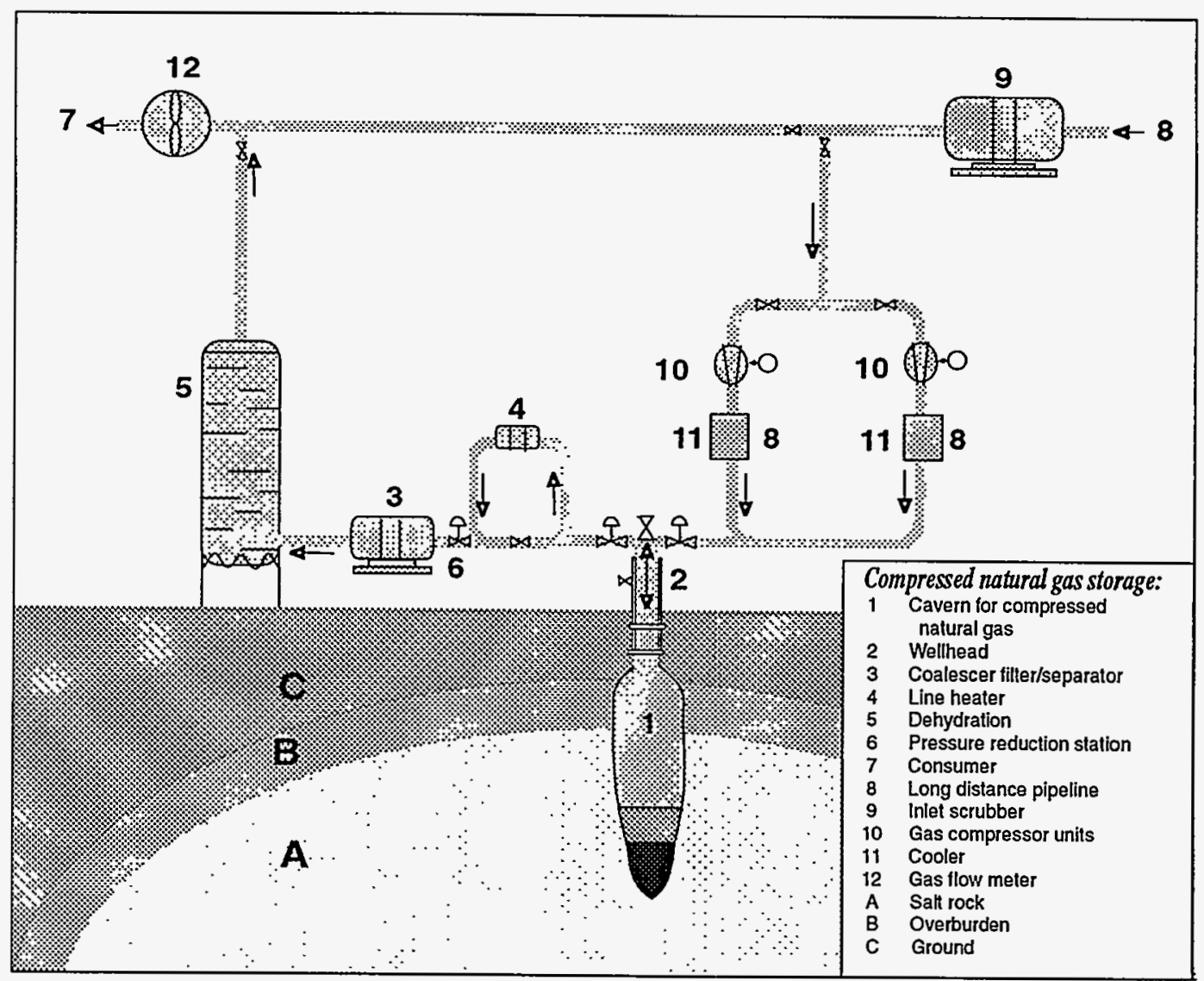

Source: PB-KBB Inc., "Underground Storage and Subsurface Systems": Recreated by Energy Information Administration, Office of Planning, Management, and Information Services.

There are two basic types of salt formations used to store natural gas: domes and beds. Salt domes are very thick salt formations. A salt dome formation might be a mile in diameter, 30,000 feet in height, and begin about 1,500 feet below the surface. The depth of the caverns that are hollowed out within the formation is critical for reasons of pressure and structural integrity. The pressure at which the gas can be stored is a function of the depth of the cavern. However, at extreme depths, as temperature and pressure increases, salt behaves as a plastic and will creep or flow, which can become a major consideration in cavern construction possibly leading to cavern closure. Thus, salt storage is generally limited to depths shallower than 6,000 feet.
A salt bed storage site, on the other hand, is generally developed from a much thinner salt formation $(1,000$ feet or less) located at shallower depths. As a result, the height-towidth ratio of the leached cavern is much less than with dome reservoirs, which are relatively high and narrow. Salt bed storage formations also contain much higher amounts of insoluble particles (shale and anhydrite rock) than salt dome formations. These materials remain in the reservoir after the leaching process and affect the flow velocity and capacity of the reservoir itself. In addition, because the height/width aspect is thin, the flatter reservoir ceiling is subject to greater stress and potential wall deterioration. As a result of these as well as other factors, salt bed storage development and operation can be more expensive than that of salt dome storage. 
Salt bed or dome storage is prepared by injecting water (leaching) into a salt formation and shaping a cavern. ${ }^{46}$ It is the most costly of the three types of facilities to develop, often two to three times more expensive. Because they are susceptible to cavern wall deterioration over time and to salt water incursion, these facilities may incur high workover costs, as well as additional expenses for special equipment on site. However, deliverability rates are high because a salt formation reservoir is essentially a high-pressure storage vessel (that is, an underground tank). Base gas requirements are low (about 25 percent) and can usually be withdrawn fully in an emergency. On average, salt formation storage is capable of multiple cycling of inventory per year, in comparison to the typical one cycle or less for depleted gas/oil field and aquifer storage. As such, salt formation storage is well suited for meeting large swings in demand.

Eleven of the existing natural gas salt storage formation sites once were used to store natural gas liquids (NGL) or brine and were converted to natural gas storage. Although more than 100 salt formation caverns in the United States and Canada are used to store NGL's, not too many conversions are expected because most of them are extremely small in size.

A salt cavern site occupies a much smaller area than an oil or gas reservoir. On average, the amount of acreage taken up by a depleted gas/oil field reservoir is more than a hundred times the amount of acreage taken up by a salt dome. Consequently, a salt cavern storage operation is generally easier to monitor than a gas/oil field reservoir operation made up of many wells.

Development time is also much less for salt formation storage than for gas/oil field reservoirs. On average, it takes about 18 to 24 months to develop a salt reservoir while a gas/oil field reservoir takes 24 to 36 months. Thus, a new salt formation storage site will begin to pay off sooner than a gas/oil field reservoir.

For the same working gas capacity, new salt formation storage reservoirs are also capable of yielding much greater revenues for a heating season than conventional gas/oil field

\footnotetext{
"The Icaching process requires drilling a well into the salt structure, one or more wells for brine disposal, fresh water sources (frequently a well is drilled into freshwater formations), pumps for fresh water injection and brine disposal, a pump and storage tank for the blanket liquid used to control upward leaching of the cavern roof, the blanket material (usually a light hydrocarbon), and the associated gathering lines connecting the wells and pumps. The total quantity of water that must be cycled through the cavern is 7 to 10 times the cavern volume. The entire leaching and dewatering process takes from 4 to 6 months per Bcf of gas storage volume. In an area where fresh water supplies are limited, leaching time may be significantly extended. Leaching costs, excluding disposal wells and costs directly associated with drilling the injection/withdrawal well, make up roughly 15 to 25 percent of the average salt cavern storage project.
}

reservoirs. This is because the working gas capacity of a salt formation storage facility can be turned over three, four, or more times during a heating season while generally a gas/oil field operation can be turned over only once. Most of the Nation's salt dome storage facilities are located in Texas, Mississippi, and Louisiana. Although used effectively by electric utilities in the South to satisfy daytime peak cooling loads during the summer, several salt cavern operations located in Louisiana and Mississippi have attracted LDC's as well as other types of customers located in the Northeastern United States. Perhaps in response to this demand, several salt storage sites are being developed in New York State (see Appendix B). These facilities would augment directly the operations of nearby gas distribution companies.

In summary, although they are the most expensive type of storage to develop and maintain, salt formation storage facilities permit withdrawals at high rates and can be drawn down quickly in emergency situations. As such, salt formation sites are well suited for peaking operations to meet dramatic swings in gas demand.

\section{Other Types of Natural Gas Storage}

\section{LNG Storage}

Liquefied natural gas (LNG) storage facilities are also used for peaking purposes, but relative to underground storage projects are much more expensive to institute and maintain. LNG is generally used as a peak-shaving medium (see the following section) in areas where underground storage or facilities for other supplemental fuels, such as liquefied petroleum gases, are unavailable or inappropriate. In such situations, natural gas in the gaseous state is received via pipelines and is locally transformed at very low temperatures into the liquid state and placed in specially built LNG storage tanks. During peak-load periods it is returned to the gaseous form and fed into the local distribution system.

During the late 1960 's, the concept of importing LNG into the United States as a supplemental supply of gas was first proposed. Even though transportation and storage costs were recognized as potentially very high, the source gas was initially very low-priced. While overall cost per unit remained high relative to domestic natural gas, much of the incremental cost of LNG use was included in the rate base. Because planning and system development for such an undertaking require long lead times, it was not until the mid-1970's that many of the elements were finally in place. By then, however, prices for imported energy products, including LNG, changed the outlook for LNG imports as a competitive gas source. LNG imports reached a high of 252 billion cubic feet in 1979, but because of contractual and pricing problems with foreign 
suppliers, for the most part the flow of LNG imports virtually ceased by 1981 .

LNG imports have never attained a significant place in the overall supply market. In 1993, LNG imports were only 81 billion cubic feet, accounting for less than 1 percent of domestic consumption and only 9 percent of underground storage withdrawals. Today, only two companies continue to import LNG supplies: Trunkline Gas Company into its Lake Charles, Louisiana, site and Distrigas of Massachusetts into its Boston (Everett) facility. LNG imports, as a peaking source relative to underground storage, maintain only a minor niche in the current storage system.

\section{Storage for Peaking and Peak-shaving}

Underground natural gas storage inventories provide suppliers with the means to meet peak customer requirements up to a point. Beyond that point the distribution system still must be capable of meeting customer short-term peaks and swings that occur on a daily and even hourly basis. During periods of extreme usage, peaking facilities, as well as other sources of temporary storage, are relied upon to supplement system and underground storage supplies.

Peaking needs are met in several ways. Some underground storage sites are designed to provide peaking service, but most often LNG and liquefied petroleum gas such as propane are vaporized and injected into the gas distribution system supply to meet instant requirements (Figure A.5). Short-term linepacking is also used to meet anticipated surge requirements. Above-ground natural gas holders are sometimes available.

The use of peaking facilities, as well as underground storage, is essentially a risk-management calculation, known as peakshaving. The cost of installing these facilities is such that the incremental cost per unit is expensive, perhaps as high as $\$ 10$ per thousand cubic feet. However, the cost of a service interruption, as well as the cost to an industrial customer in lost production, may be much higher. In the case of underground storage, a suitable site may not be locally available. The only other alternative might be to build or reserve the needed additional capacity on the pipeline network. Each alternative entails a cost.

A local gas distribution company (LDC) installs supplemental supply sources (underground storage, LNG, and propane) and uses linepacking to "shave" as much of the difference between the total maximum user requirements (on a peak day or shorter period) and the baseload customer requirements (the normal or average) daily usage. Each unit "shaved" represents less demand charges (for reserving pipeline capacity on the trunklines between supply and market areas) that the LDC must pay. The objective is to maintain sufficient local underground storage capacity to minimize capacity reservation costs on the supplying pipeline by using conventional storage and also having in place additional supply sources such as LNG and propane air to meet large shifts in daily demand. In these instances, the tradeoff is between high-deliverability storage such as salt dome facilities and propane-air plants.

Although peaking facilities are often used only a few days a year, their availability is critical. For instance, if it were not for these facilities:

- More long-haul pipeline capacity, and in many cases local pipeline deliverability, would have to be built to serve end-use customers.

- Much more underground storage would have to be developed (if suitable sites were available) to meet peak and surge requirements in addition to seasonal supply.

- More large industrial and electric utility users of natural gas would have to have the capability to fuel-switch during peak periods. 
Figure A5. Propane Underground Storage Cavern

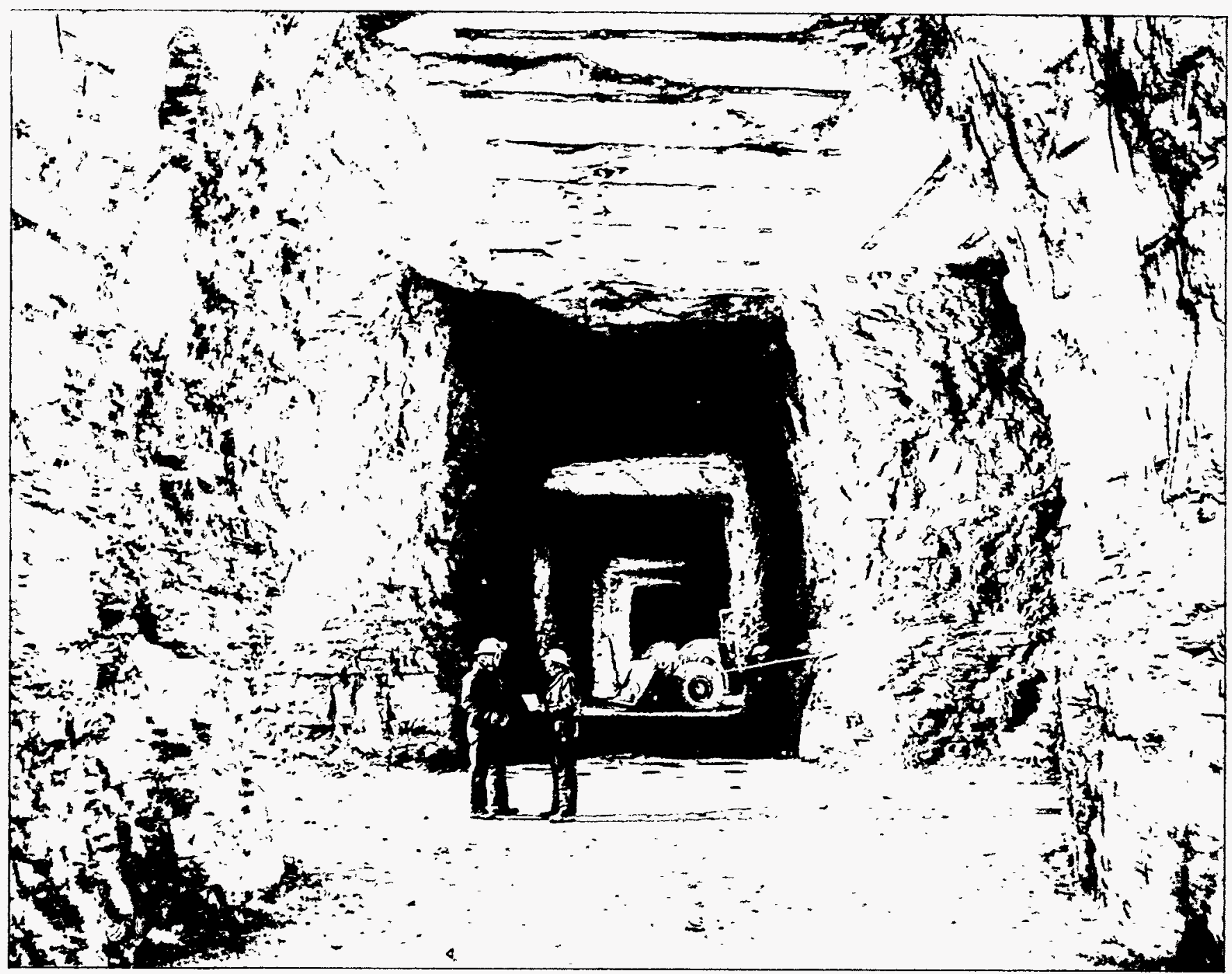

Source: PB-KBB Inc. (Houston, TX). 

Appendix B

Proposed Additions to Underground Storage 


\section{Appendix B}

\section{Proposed Additions to Underground Storage}

This appendix presents an overview of natural gas underground storage projects proposed to be completed by the end of the decade. As of October 1994, 47 new and 34 expansion storage projects had been announced (Figure B1). These projects would add approximately 495 billion cubic feet (Bcf) to U.S. working gas capacity, which represents an increase of 13 percent over 1993 levels (Table B1). Moreover, this activity will generate an additional 21 Bcf of daily deliverability from storage, 31 percent above the 1993 level. The total estimated capital outlay (development cost) for these 81 proposed projects is $\$ 2.2$ billion.

Most of the planned working gas capacity development is the traditional depleted gas/oil reservoir type (65 percent), yet this component accounts for only 31 percent of the planned increase in daily deliverability and only a 10-percent increase over 1993 daily deliverability. In contrast, while salt cavern storage projects represent only 33 percent of the planned increase in working gas capacity, they account for more than 68 percent of the planned increase in daily deliverability (21 percent above the total 1993 daily deliverability of nearly 68 Bcf).

Many of the projects represent expansions to existing or planned salt storage facilities. Twenty-five salt cavern expansion projects, with about $6 \mathrm{Bcf}$ of daily deliverability from additional salt cavern reservoirs, are proposed. Depleted gas/oil and aquifer reservoir expansion projects (9), on the other hand, represent an increase of only 568 million cubic feet per day in deliverability. This is only 10 percent as much as for salt cavern expansion projects and only a 1-percent increase over existing 1993 depleted gas/oil and aquifer reservoir levels. Many proposals also include plans to construct interconnecting lines with other pipeline systems or additional surface facilities to expand deliverability or provide additional services.

Some projects have firm commitments with customers and/or are already under construction. Others are in the engineering design stage or only the early stages of conceptualization. Several projects have yet to announce a planned inservice date. Many projects are competing for overlapping markets and will be withdrawn when earlier or lower cost entrants secure their target customer base. Others will be canceled or delayed because of market or regulatory changes.
The secondary storage market under FERC Order 636 will have a major influence on the ultimate success of these projects. Under most compliance plans, the existing customers of the pipeline companies (primarily distribution companies) were awarded most of the existing storage capacity with the remainder going to the pipeline companies to support no-notice services and system management. As a result, little additional storage was available initially to third parties as a result of unbundling. However, a secondary storage market has developed as distributors have adapted their supply plans and strategies to the post- 636 world. Yet, at this point it is too early to determine if this secondary market will offer old storage or pull in new storage. The evolution of the marketplace during the next 2 to 3 years should provide valuable insights into these issues.

A variety of companies are active in the development of underground storage (Table B2). These include intrastate and interstate pipeline companies, local distribution companies (LDC's), independent storage developers, marketers, producers, and electric utilities. In several cases, multiple parties are jointly developing a project, such as the Avoca salt bed facility in New York. In this case, J. Makowski \& Associates is developing the project with participation by Natural Gas Clearinghouse, Texaco Gas Inc, Tennessee Gas Pipeline Company, Union Gas of Canada, and Equitrans Inc.

Although interstate pipeline companies have been the dominant providers of underground storage and currently manage the majority of storage capacity in the United States, projects sponsored by interstate pipeline companies account for only 14 percent of the proposed additions to working gas capacity. Today, independent storage operators are the principal initiators of new storage projects. They have entered the storage market in unprecedented numbers, with many developing new salt cavern storage sites or other high-deliverability sites. Such facilities, with their high daily deliverability rates, offer the potential for lower per-unit operational costs (because of their capability to provide high turnover in gas inventories, or multiple cycling of inventories over time).

Some interstate pipeline companies are the primary sponsor of a project, as in the case of Questar's expansion of its Clay 
Figure B1. Locations of Storage Projects Planned Through 1999

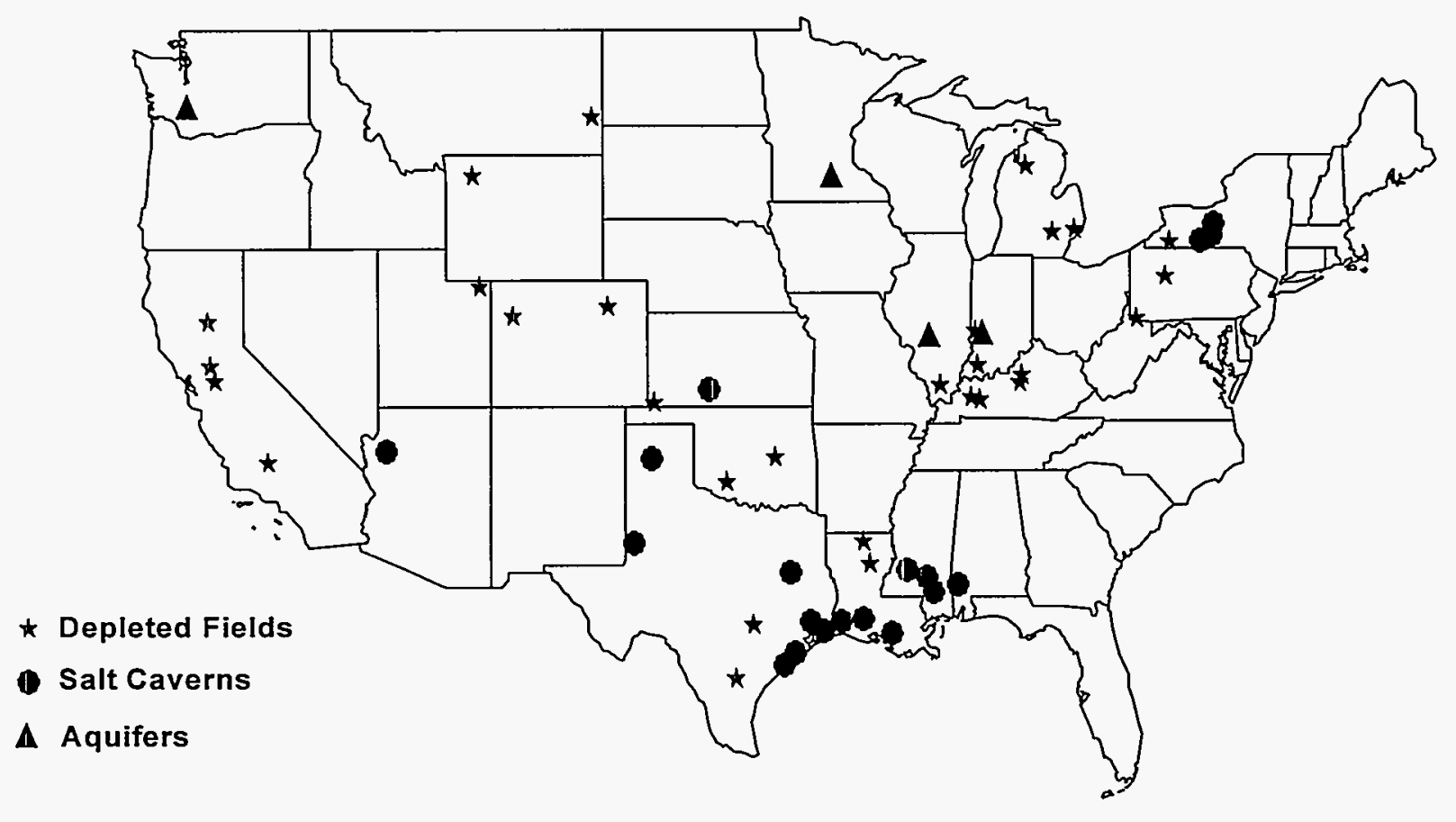

Source: Energy Information Administration, Office of Oil and Gas, Natural Gas Pipeline Geographic Information System (November 1994).

Basin facility. Others are either entering into joint storage ventures with LDC's and independents or are forming subsidiary companies to develop underground storage projects that may or may not serve the pipeline's traditional market. For example, Enron Storage Inc., which was formed to develop primarily nonjurisdictional facilities, is sponsoring the proposed Mullinville (Kansas) bedded salt facility and the Napoleonville (Louisiana) salt cavern facility.

\section{Integration of New Storage}

Most new storage is being planned with access to multiple pipelines, that is, around market (pooling) hubs, being a major consideration. This feature permits service and transportation flexibility, which will enhance a pipeline company's capability to provide reliable no-notice and other services.
The strategic placement of new storage sites in the vicinity of, or with ready access to, multiple pipeline transporters around market hubs is enabling new operators to compete effectively with traditional storage operators. Of the 47 distinct storage projects, about 20 are located in areas near or adjacent to what have become known as market pooling points or have been proposed as such.

\section{Expanded Service Offerings}

Developers see a variety of roles for underground storage located at or near a hub. Key services include supply balancing and emergency backup. Conceptually, a combined storage/hub facility would act as a minipipeline system that transferred gas between sellers and buyers and balanced daily fluctuations in deliveries to meet nominated volumes on the 
Table B1. Summary of Proposed Storage Projects by Reservoir Type and Projected Year in Service

\begin{tabular}{|c|c|c|c|c|c|c|c|c|c|c|c|c|}
\hline \multirow[b]{2}{*}{ Year } & \multicolumn{3}{|c|}{ Depleted Gas/Oil } & \multicolumn{3}{|c|}{ Aquifer Storage } & \multicolumn{3}{|c|}{ Salt Cavern Storage } & \multicolumn{3}{|c|}{ Total } \\
\hline & $\begin{array}{c}\text { Number } \\
\text { of } \\
\text { Projects }\end{array}$ & $\begin{array}{c}\text { Working } \\
\text { Gas } \\
\text { Capacity } \\
\text { (Bcf) }\end{array}$ & $\begin{array}{c}\text { Daily } \\
\text { Deliver- } \\
\text { ability } \\
\text { (MMcf) }\end{array}$ & $\begin{array}{c}\text { Number } \\
\text { of } \\
\text { Projects }\end{array}$ & $\begin{array}{c}\text { Working } \\
\text { Gas } \\
\text { Capacity } \\
\text { (Bcf) }\end{array}$ & $\begin{array}{l}\text { Daily } \\
\text { Deliver- } \\
\text { ability } \\
\text { (MMcf) }\end{array}$ & $\begin{array}{c}\text { Number } \\
\text { of } \\
\text { Projects }\end{array}$ & $\begin{array}{c}\text { Working } \\
\text { Gas } \\
\text { Capacity } \\
\text { (Bcf) }\end{array}$ & $\begin{array}{c}\text { Daily } \\
\text { Deliver- } \\
\text { ability } \\
\text { (MMcf) }\end{array}$ & $\begin{array}{l}\text { Number } \\
\text { of } \\
\text { Projects }\end{array}$ & $\begin{array}{c}\text { Working } \\
\text { Gas } \\
\text { Capacity } \\
\text { (Bcf) }\end{array}$ & $\begin{array}{c}\text { Daily } \\
\text { Deliver- } \\
\text { ability } \\
\text { (MMcf) }\end{array}$ \\
\hline Existing 1993 & 316 & 3,170 & 53,380 & 38 & 443 & 7,306 & 21 & 82 & 7,041 & 375 & 3,695 & 67,729 \\
\hline $\begin{array}{l}1994 \\
\text { New } \\
\text { Expansion } \\
\text { Total }\end{array}$ & $\begin{array}{r}10 \\
5 \\
15\end{array}$ & $\begin{array}{r}144 \\
17 \\
161\end{array}$ & $\begin{array}{r}2,600 \\
383 \\
2,983\end{array}$ & $\begin{array}{l}1 \\
1 \\
2\end{array}$ & $\begin{array}{l}3 \\
4 \\
8\end{array}$ & $\begin{array}{r}35 \\
75 \\
110\end{array}$ & $\begin{array}{r}6 \\
5 \\
11\end{array}$ & $\begin{array}{l}23 \\
11 \\
34\end{array}$ & $\begin{array}{r}1,630 \\
990 \\
2,620\end{array}$ & $\begin{array}{l}17 \\
11 \\
28\end{array}$ & $\begin{array}{r}172 \\
33 \\
205\end{array}$ & $\begin{array}{l}4,265 \\
1,448 \\
5,713\end{array}$ \\
\hline \multicolumn{13}{|l|}{1995} \\
\hline $\begin{array}{l}\text { New } \\
\text { Expansion } \\
\text { Total }\end{array}$ & $\begin{array}{l}8 \\
1 \\
9\end{array}$ & $\begin{array}{r}114 \\
5 \\
119\end{array}$ & $\begin{array}{r}2,312 \\
50 \\
2,362\end{array}$ & $\begin{array}{l}0 \\
0 \\
0\end{array}$ & $\begin{array}{l}0 \\
0 \\
0\end{array}$ & $\begin{array}{l}0 \\
0 \\
0\end{array}$ & $\begin{array}{r}11 \\
6 \\
17\end{array}$ & $\begin{array}{l}45 \\
16 \\
61\end{array}$ & $\begin{array}{l}4,575 \\
1,040 \\
5,615\end{array}$ & $\begin{array}{r}19 \\
7 \\
26\end{array}$ & $\begin{array}{r}159 \\
21 \\
180\end{array}$ & $\begin{array}{l}6,887 \\
1,090 \\
7,977\end{array}$ \\
\hline \multicolumn{13}{|l|}{1996} \\
\hline $\begin{array}{l}\text { New } \\
\text { Expansion } \\
\text { Total }\end{array}$ & $\begin{array}{l}3 \\
1 \\
4\end{array}$ & $\begin{array}{r}13 \\
6 \\
19\end{array}$ & $\begin{array}{r}940 \\
60 \\
1,000\end{array}$ & $\begin{array}{l}0 \\
1 \\
1\end{array}$ & $\begin{array}{l}0 \\
1 \\
1\end{array}$ & $\begin{array}{l}0 \\
0 \\
0\end{array}$ & $\begin{array}{l}4 \\
3 \\
7\end{array}$ & $\begin{array}{r}12 \\
8 \\
20\end{array}$ & $\begin{array}{r}970 \\
800 \\
1,770\end{array}$ & $\begin{array}{r}7 \\
5 \\
12\end{array}$ & $\begin{array}{l}25 \\
15 \\
40\end{array}$ & $\begin{array}{r}1,910 \\
860 \\
2,770\end{array}$ \\
\hline \multicolumn{13}{|l|}{1997} \\
\hline Expansion & 0 & 0 & 0 & 0 & 0 & 0 & 6 & 22 & 2,000 & 6 & 22 & 2,000 \\
\hline Total & 0 & 0 & 0 & 0 & 0 & 0 & 6 & 22 & 2,000 & 6 & 22 & 2,000 \\
\hline \multicolumn{13}{|l|}{1998} \\
\hline New & 0 & 0 & 0 & 0 & 0 & 0 & 1 & 9 & 1,000 & 1 & 9 & 1,000 \\
\hline $\begin{array}{l}\text { Expansion } \\
\text { Total }\end{array}$ & $\begin{array}{l}0 \\
0\end{array}$ & $\begin{array}{l}0 \\
0\end{array}$ & $\begin{array}{l}0 \\
0\end{array}$ & $\begin{array}{l}0 \\
0\end{array}$ & $\begin{array}{l}0 \\
0\end{array}$ & $\begin{array}{l}0 \\
0\end{array}$ & $\begin{array}{l}5 \\
6\end{array}$ & $\begin{array}{l}16 \\
25\end{array}$ & $\begin{array}{l}1,100 \\
2,110\end{array}$ & $\begin{array}{l}5 \\
6\end{array}$ & $\begin{array}{l}16 \\
25\end{array}$ & $\begin{array}{l}1,110 \\
2,110\end{array}$ \\
\hline $\begin{array}{l}1999 \\
\text { New } \\
\text { Total }\end{array}$ & $\begin{array}{l}3 \\
3\end{array}$ & $\begin{array}{l}21 \\
21\end{array}$ & $\begin{array}{l}176 \\
176\end{array}$ & $\begin{array}{l}0 \\
0\end{array}$ & $\begin{array}{l}0 \\
0\end{array}$ & $\begin{array}{l}0 \\
0\end{array}$ & $\begin{array}{l}0 \\
0\end{array}$ & $\begin{array}{l}0 \\
0\end{array}$ & $\begin{array}{l}0 \\
0\end{array}$ & $\begin{array}{l}3 \\
3\end{array}$ & $\begin{array}{l}21 \\
21\end{array}$ & $\begin{array}{l}176 \\
176\end{array}$ \\
\hline \multicolumn{13}{|l|}{ Total 1994-99 } \\
\hline $\begin{array}{l}\text { New } \\
\text { Expansion } \\
\text { Total }\end{array}$ & $\begin{array}{r}24 \\
7 \\
31\end{array}$ & $\begin{array}{r}293 \\
28 \\
322\end{array}$ & $\begin{array}{r}6,028 \\
493 \\
6,521\end{array}$ & $\begin{array}{l}1 \\
2 \\
3\end{array}$ & $\begin{array}{l}3 \\
5 \\
9\end{array}$ & $\begin{array}{r}35 \\
75 \\
110\end{array}$ & $\begin{array}{l}22 \\
25 \\
47\end{array}$ & $\begin{array}{r}89 \\
74 \\
164\end{array}$ & $\begin{array}{r}8,175 \\
5,940 \\
14,115\end{array}$ & $\begin{array}{l}47 \\
34 \\
81\end{array}$ & $\begin{array}{l}387 \\
108 \\
495\end{array}$ & $\begin{array}{r}14,238 \\
6,508 \\
20,746\end{array}$ \\
\hline
\end{tabular}

Bcf $=$ Billion cubic feet. MMcf $=$ Million cubic feet.

Note: Two liquefied natural gas storage projects (one new, one expansion) have also been proposed for 1995 and 1998, respectively, which would add $4 \mathrm{Bcf}$ working gas capacity and 1,000 MMcf daily deliverability. Totals may not equal sum of components because of independent rounding.

Source: Energy Information Administration, Office of Oil and Gas, "Proposed Natural Gas Storage Projects," data base as of October 31, 1994, based on Federal Energy Regulatory Commission filings and information from various news sources. 
Table B2. Summary of Proposed Storage Projects by Ownership Type

\begin{tabular}{l|c|c|c|c|c|c}
\hline & \multirow{2}{*}{$\begin{array}{c}\text { Number of } \\
\text { Type of Owner }\end{array}$} & \multicolumn{2}{|c|}{ Capacity Additions (billion cubic feet) } & \multicolumn{2}{c}{ Additions (MMcf/d) } \\
\cline { 3 - 7 } & Projects & Base Gas & Working Gas & Total & Withdrawals & Injections \\
\hline Independent Co. & 38 & 185 & 327 & 513 & 11,095 & 3,680 \\
Interstate Pipeline Co. & 20 & 83 & 68 & 151 & 4,326 & 1,825 \\
Intrastate Pipeline Co. & 12 & 37 & 55 & 92 & 3,290 & 1,290 \\
Local Distribution Co. & 11 & 22 & 45 & 67 & 2,035 & 1,009 \\
$\quad$ Total & 81 & 328 & 495 & 824 & 20,746 & 7,804 \\
\hline
\end{tabular}

MMct/d = Million cubic feet per day.

Note: Two liquefied natural gas storage projects (one new, one expansion) have also been proposed by an interstate pipeline company affiliate, which would add $4 \mathrm{Bcf}$ working gas capacity, 1,000 MMcf/d withdrawal capacity and $15 \mathrm{MMcf} / \mathrm{d}$ injection capacity. Totals may not equal sum of components because of independent rounding.

Source: Energy information Administration, Office of Oil and Gas, "Proposed Natural Gas Storage Projects," data base as of October 31, 1994, based on Federal Energy Regulatory Commission filings and information from various news sources.

long-distance pipelines. Several developers also envision providing value added sales services to prospective buyers. "Swing services" are a prime example. These involve a gas supply contract that permits the purchaser to take less than 100 percent of the contracted volumes at variable rates that match daily and seasonal swings in demands.

A number of producers are also actively developing or participating in new underground gas storage projects. ${ }^{47}$ Producers find storage attractive as a means of levelizing their daily production flows. Putting gas in storage can be more economic for producers than putting excess gas on the spot market, or shutting in the gas. In this sense, storage serves as an operational risk management tool that is essential if a producer plans to compete as a firm supplier of gas in the unbundled market. A producer's interest in storage includes its use for:

- Aggregating supplies. In this case, storage serves as the point where a producer's various gas supplies can be pooled together and repackaged to meet customer needs.

- Improving the reliability of the producer's supplies. In this case, storage acts as an emergency backup supply in the event of equipment failures, well freezeups, or hurricanes.

- Offering value-added services to consumers. In this case, storage is used to provide services to consumers in addition to the sale of gas.

\footnotetext{
${ }^{47}$ For instance, Chevron, which is participating in the Petal Salt Dome project; Texaco, which is participating in the Avoca project; and, Amoco, which is participating in the Stratton Ridge project.
}

In addition, a number of proposed new storage projects are being developed on behalf of, or are geared toward attracting, electric utility users. Some examples include: the Hilbig project in Bastrop, Texas, which will be used for the Lower Colorado River Authority's gas-fired units; the Nichols Station Plant project, which is under consideration by Southwest Public Service as a backup supply source for its Nichols Plant; the Spindletop project being developed by Sabine Gas Transmission to serve Gulf States Utilities; and several California projects that are competing to supply the Sacramento Municipal Utility District, including the Wild Goose, the Lodi, and the Putah Sink projects These users in particular need high-deliverability type storage to service their varying weekly, daily, and even hourly peaking needs.

New storage is also being marketed by some storage developers as a potential price arbitrage and futures trading hedging tool. Many in the industry, however, feel this service will evolve into only a very small niche market, offering little in the way of a major income source or opportunity for profit.

\section{Emphasis on Salt Facilities}

Conversions of depleted fields are expected to provide 65 percent of proposed additional working gas capacity. In general, depleted field conversions still offer the most costeffective choice for seasonal baseload storage supply, and about 29 percent of the depleted field projects are expansions of existing storage fields. Salt cavern facilities (both bedded and dome) account for an additional 33 percent of proposed additions to working gas capacity, and aquifers 2 percent. The salt cavern facilities, however, account for the large majority of additions to withdrawal capacity (68 percent in total or 
approximately 2.1 times their contribution to working gas capacity).

The large number of proposed salt cavern projects represents an interesting departure from the historical trend of storage development in depleted fields. Salt cavern facilities are essentially large underground caverns that act as pressure vessels (see Appendix A). As a result, these facilities have very high withdrawal rates relative to their working gas capacities. Most salt cavern facilities are designed to deliver their total working gas capacity in a period of 10 to 15 days and have sufficient injection capacity to replace this working gas in 20 to 30 days. The high-deliverability, low-volume capacity associated with these facilities, and their ability to inject and withdraw gas on a continuing basis throughout the year, make salt cavern facilities particularly attractive for providing a number of upstream storage services now in high demand in the unbundled market environment (i.e., balancing, emergency backup). In contrast, storage in depleted fields and aquifers is not easily configured to provide these services as the withdrawal and injection rates for storage in these fields are restricted by the much lower permeability of the storage formation.

Several developers are also marketing salt dome and salt bed facilities as a peaking supply source. The high-deliverability rates possible from these facilities make them attractive for peaking uses. However, peaking facilities generally need to be located in close proximity to the customer purchasing the service in order to assure prompt delivery of the gas. Salt domes in the producing regions, therefore, generally cannot offer peaking service to customers in other regions of the United States. However, several proposed projects using salt bed deposits are located in, or relatively near, major market areas in the Northeast and Western United States, making them attractive for development and use as peaking supply.

Proposed salt cavern facilities also differ from existing storage with respect to the planned operation of the facilities. Most proposed salt caverns are designed with the intent of cycling the entire working gas capacity several times each year. This requires the installation of substantial compressor capacity for re-injecting gas in a short period.

\section{Locations of New Storage}

Most of the increased storage capacity is slated for development in Texas. With 15 projects, Texas storage deliverability could increase by 44 percent by 1998 while working gas capacity could expand by 22 percent, adding over 4 billion cubic feet per day to deliverability and 80 billion cubic feet of working gas capacity overall. But on a percentage basis, Louisiana's planned growth is even more remarkable, with a 38-percent increase in working gas capacity and more than double the current daily deliverability. New York and California will also see significant growth in their underground storage services. All of these States are homes of major market hubs and, with the exception of California, have geologic salt formations which will be used for much of the planned storage. California, however, does possess the geology to permit development of high-deliverability storage in nonsalt reservoirs-for example, the Wild Goose project in Butte County.

Each project, by location, is detailed in Table B3. 


\begin{tabular}{|c|c|c|c|c|c|c|}
\hline Project Name/State & Operator & County & $\begin{array}{l}\text { Year in } \\
\text { Service }\end{array}$ & $\begin{array}{c}\text { Expansion } \\
\text { Project? } \\
\text { (X=Yes) }\end{array}$ & $\begin{array}{l}\text { FERC } \\
\text { Docket } \\
\text { Number }\end{array}$ & $\begin{array}{l}\text { Reservoir } \\
\text { Type }\end{array}$ \\
\hline \multicolumn{7}{|l|}{ ALABAMA } \\
\hline $\begin{array}{l}\text { SOUTH } \\
\text { ALABAMA-MCINTOSH }\end{array}$ & BAY GASSTG-MOBILE & WASHINGTON & 1994 & & & SALT DOME \\
\hline \multicolumn{7}{|l|}{ ARIZONA } \\
\hline PATAYA PHASE 1 & $\begin{array}{l}\text { GOLDEN STORAGE } \\
\text { SERVICES }\end{array}$ & MOHAVE & 1996 & & & SALT BED \\
\hline PATAYA PHASE 2 & $\begin{array}{l}\text { GOLDEN STORAGE } \\
\text { SERVICES }\end{array}$ & MOHAVE & 1998 & $\mathrm{x}$ & & SALT BED \\
\hline TRANAM PHASE 1 & TRAN AM ENERGY & MOHAVE & 1995 & & & SALT BED \\
\hline TRANAM PHASE 2 & TRAN AM ENERGY & MOHAVE & 1998 & & & SALT BED \\
\hline \multicolumn{7}{|l|}{ CALIFORNIA } \\
\hline LODI & $\begin{array}{l}\text { NORTHERN CA. GAS } \\
\text { STORAGE }\end{array}$ & SAN JOAQUIN & 1995 & & & DEPL FIELD \\
\hline PUTAH SINK & NAHAMA \& WEAGANT & SACRAMENTO & 1995 & & & DEPL FIELD \\
\hline TEN SECTION & MCFARLAND ENERGY & KERN & 1995 & & & DEPL FIELD \\
\hline WILD GOOSE & $\begin{array}{l}\text { WILD GOOSE GAS } \\
\text { STORAGE }\end{array}$ & BUTTE & 1995 & & & DEPL FIELD \\
\hline \multicolumn{7}{|l|}{ COLORADO } \\
\hline DOUGLAS CREEK & WILLIAMS STORAGE & RIO BLANCO & 1994 & & & DEPL FIELD \\
\hline YOUNG & CIG & MORGAN & 1994 & & & DEPL FIELD \\
\hline \multicolumn{7}{|l|}{ ILLINOIS } \\
\hline HILLSBORO EXPANSION & ILLINOIS POWER & MONTGOMERY & 1994 & $x$ & & AQUIFER \\
\hline JOHNSON CITY & $\begin{array}{l}\text { CENTRAL ILLINOIS } \\
\text { PUBLIC }\end{array}$ & WILLIAMSON & 1996 & & & DEPL FIELD \\
\hline \multicolumn{7}{|l|}{ INDIANA } \\
\hline CARBON-CALCUTTA & MIDWEST GAS STORAGE & CLAY & 1994 & & CP90-454 & AQUIFER \\
\hline \multicolumn{7}{|l|}{ KANSAS } \\
\hline MID-CONTINENT PHASE 1 & HNG STORAGE & KIOWA & 1995 & & & SALT BED \\
\hline MID-CONTINENT PHASE 2 & HNG STORAGE & KIOWA & 1996 & $x$ & & SALT BED \\
\hline MID-CONTINENT PHASE 3 & HNG STORAGE & KIOWA & 1997 & $x$ & & SALT BED \\
\hline MID-CONTINENT PHASE 4 & HNG STORAGE & KIOWA & 1998 & $x$ & & SALT BED \\
\hline MULLINVILLE & ENRON STORAGE & KIOWA & 1995 & & & SALT BED \\
\hline RICHFIELD WEST FIELD & $\begin{array}{l}\text { CENTENNIAL STORAGE, } \\
\text { NUEVO }\end{array}$ & MORTON & 1994 & & CP92-285 & DEPL FIELD \\
\hline RICHFIELD WEST FIELD & $\begin{array}{l}\text { CENTENNIAL STORAGE, } \\
\text { NUEVO }\end{array}$ & MORTON & 1994 & $x$ & & DEPL FIELD \\
\hline \multicolumn{7}{|l|}{ KENTUCKY } \\
\hline ELK CREEK & HAR-KEN & SPENCER & 1999 & & & DEPL FIELD \\
\hline SOUTH ST. CHARLES & HAR-KEN & HOPKINS & 1999 & & & DEPL FIELD \\
\hline ST. CHARLES & HAR-KEN & HOPKINS & 1999 & & & DEPL FIELD \\
\hline \multicolumn{7}{|l|}{ LOUISIANA } \\
\hline CHANDELEUR & ENTRE ENERGY & OFFSHORE & 1994 & & CP94-389 & DEPL FIELD \\
\hline COTTON PLANT & $\begin{array}{l}\text { SWIFT/NG CLEARING } \\
\text { HOUSE }\end{array}$ & CALDWELL & 1994 & & & DEPL FIELD \\
\hline
\end{tabular}


Table B3. Proposed Underground Storage by State, 1994-1999 (Continued)

\begin{tabular}{|c|c|c|c|c|c|c|}
\hline \multirow[b]{2}{*}{ Project Name/State } & \multicolumn{3}{|c|}{$\begin{array}{c}\text { Capacity } \\
\text { (billion cubic feet) }\end{array}$} & \multicolumn{2}{|c|}{$\begin{array}{c}\text { Capacity } \\
\text { (MMcf per day) }\end{array}$} & \multirow[b]{2}{*}{$\begin{array}{l}\text { Total Cost } \\
\text { (Thousand \$) }\end{array}$} \\
\hline & Total & Base Gas & $\begin{array}{l}\text { Working } \\
\text { Gas }\end{array}$ & Withdrawal & Injection & \\
\hline \multicolumn{7}{|l|}{ ALABAMA } \\
\hline $\begin{array}{l}\text { SOUTH } \\
\text { ALABAMA-MCINTOSH }\end{array}$ & 4.00 & 1.30 & 2.70 & 100 & 25 & $\$ 30,000$ \\
\hline TOTALS: Projects=1 & 4.00 & 1.30 & 2.70 & 100 & 25 & $\$ 30,000$ \\
\hline \multicolumn{7}{|l|}{ ARIZONA } \\
\hline PATAYA PHASE 1 & 9.00 & 3.00 & 6.00 & 250 & 120 & $\$ 41,000$ \\
\hline PATAYA PHASE 2 & 9.00 & 3.00 & 6.00 & 250 & 120 & $\$ 18,000$ \\
\hline TRANAM PHASE 1 & 11.00 & 0.00 & 11.00 & 1000 & 0 & \$o \\
\hline TRANAM PHASE 2 & 9.00 & 0.00 & 9.00 & 1000 & 0 & \$o \\
\hline TOTALS: Projects $=4$ & 38.00 & 6.00 & 32.00 & 2,500 & 240 & $\$ 59,000$ \\
\hline \multicolumn{7}{|l|}{ CALIFORNIA } \\
\hline LODI & 24.00 & 16.00 & 8.00 & 250 & 130 & $\$ 25,000$ \\
\hline PUTAH SINK & 23.00 & 8.00 & 15.00 & 214 & 107 & $\$ 40,000$ \\
\hline TEN SECTION & 65.00 & 25.00 & 40.00 & 600 & 200 & $\$ 55,000$ \\
\hline WILD GOOSE & 9.00 & 3.00 & 6.00 & 400 & 200 & $\$ 90,000$ \\
\hline TOTALS: Projects $=4$ & 121.00 & 52.00 & 69.00 & 1,464 & 637 & 210,000 \\
\hline \multicolumn{7}{|l|}{ COLORADO } \\
\hline DOUGLAS CREEK & 17.00 & 7.00 & 10.00 & 200 & 250 & $\$ 30,000$ \\
\hline YOUNG & 10.00 & 4.70 & 5.30 & 200 & 100 & $\$ 44,400$ \\
\hline TOTALS: Projects $=2$ & 27.00 & 11.70 & 15.30 & 400 & 350 & $\$ 74,400$ \\
\hline \multicolumn{7}{|l|}{ ILLINOIS } \\
\hline HILLSBORO EXPANSION & 11.50 & 7.00 & 4.50 & 75 & 27 & $\$ 36,600$ \\
\hline JOHNSON CITY & 1.60 & 0.60 & 1.00 & 10 & 7 & $\$ 2,600$ \\
\hline TOTALS: Projects $=2$ & 13.10 & 7.60 & 5.50 & 85 & 34 & $\$ 39,200$ \\
\hline \multicolumn{7}{|l|}{ INDIANA } \\
\hline CARBON-CALCUTTA & 5.50 & 1.60 & 3.90 & 35 & 18 & $\$ 12,275$ \\
\hline TOTALS: Projects $=1$ & 5.50 & 1.60 & 3.90 & 35 & 18 & $\$ 12,275$ \\
\hline \multicolumn{7}{|l|}{ KANSAS } \\
\hline MID-CONTINENT PHASE 1 & 1.90 & 0.65 & 1.25 & 100 & 50 & $\$ 20,000$ \\
\hline MID-CONTINENT PHASE 2 & 1.90 & 0.65 & 1.25 & 100 & 50 & $\$ 11,000$ \\
\hline MID-CONTINENT PHASE 3 & 1.90 & 0.65 & 1.25 & 100 & 50 & $\$ 11,000$ \\
\hline MID-CONTINENT PHASE 4 & 1.90 & 0.65 & 1.25 & 100 & 50 & $\$ 11,000$ \\
\hline MULLINVILLEE & 7.50 & 2.50 & 5.00 & 500 & 250 & $\$ 40,000$ \\
\hline RICHFIELD WEST FIELD & 6.50 & 3.00 & 3.50 & 50 & 12 & $\$ 12,000$ \\
\hline RICHFIELD WEST FIELD & 1.50 & 0.00 & 1.50 & 30 & 0 & $\$ 0$ \\
\hline TOTALS: Projects $=7$ & 23.10 & 8.10 & 15.00 & 980 & 462 & 105,000 \\
\hline \multicolumn{7}{|l|}{ KENTUCKY } \\
\hline ELK CREEK & 13.00 & 6.50 & 6.50 & 50 & 33 & $\$ 14,000$ \\
\hline SOUTH ST. CHARLES & 1.40 & 0.70 & 0.70 & 6 & 4 & $\$ 3,300$ \\
\hline ST. CHARLES & 29.50 & 14.75 & 14.75 & 120 & 80 & $\$ 51,000$ \\
\hline TOTALS: Projects $=3$ & 43.90 & 21.95 & 21.95 & 176 & 117 & $\$ 68,300$ \\
\hline \multicolumn{7}{|l|}{ LOUISIANA } \\
\hline CHANDELEUR & 26.00 & 0.00 & 26.00 & 300 & 300 & \$o \\
\hline COTTON PLANT & 46.00 & 30.00 & 16.00 & 450 & 173 & $\$ 100,000$ \\
\hline
\end{tabular}


Table B3. Proposed Underground Storage by State, 1994-1999 (Continued)

\begin{tabular}{|c|c|c|c|c|c|c|}
\hline Project Name/State & Operator & County & $\begin{array}{l}\text { Year in } \\
\text { Service }\end{array}$ & $\begin{array}{c}\text { Expansion } \\
\text { Project? } \\
\text { ( } X=Y e s)\end{array}$ & $\begin{array}{l}\text { FERC } \\
\text { Docket } \\
\text { Number }\end{array}$ & $\begin{array}{l}\text { Reservoir } \\
\text { Type }\end{array}$ \\
\hline JEFFERSON ISLAND & EQUITABLE RESOURCES & $\begin{array}{l}\text { IBERIA AND } \\
\text { VERM }\end{array}$ & 1995 & & & SALT DOME \\
\hline JENNINGS SALT DOME & EGAN GAS STORAGE CO & ACADIA & 1995 & & CP94-217 & SALT DOME \\
\hline LA-1 PHASE 3,4 & TEJAS POWER CORP & ACADIA & 1996 & $x$ & & SALT DOME \\
\hline LA-1 PHASE 5,6 & TEJAS POWER CORP & ACADIA & 1997 & $x$ & & SALT DOME \\
\hline LA-i/EGAN PHASE 1,2 & TEJAS POWER CORP & ACADIA & 1995 & & & SALT DOME \\
\hline NAPOLEONVILLE PHASE 1 & ENRON STORAGE & ASSUMPTION & 1994 & & & SALT DOME \\
\hline NAPOLEONVILLE PHASE 2 & ENRON STORAGE & ASSUMPTION & 1998 & $x$ & & SALT DOME \\
\hline OUACHITA RIVER & MATRIX PARTNERS & UNION & 1995 & & CP94-038 & DEPL FIELD \\
\hline SULPHUR MINES & HNG STORAGE & CALCASIEU & 1995 & & CP93-716 & SALT DOME \\
\hline \multicolumn{7}{|l|}{ MICHIGAN } \\
\hline GRANDS LACS & TEJAS POWER/CMS GAS & ST CLAIR & 1995 & & & SALT BED \\
\hline KALKASKA 30 & CMS ENERGY & KALKASKA & 1994 & & & DEPL FIELD \\
\hline LEE 8 & $\begin{array}{l}\text { PANHANDLE } \\
\text { STORAGEMG } \\
\text { VENTURES }\end{array}$ & CALHOUN & 1995 & & & DEPL FIELD \\
\hline LIVINGSTON EXPANSION & $\begin{array}{l}\text { GRI, PANHANDLE } \\
\text { EASTERN }\end{array}$ & LIVINGSTON & 1994 & $x$ & & DEPL FIELD \\
\hline WASHINGTON TOWNSHIP & MCN INVESTMENT & MACOMB & 1996 & & & DEPL FIELD \\
\hline \multicolumn{7}{|l|}{ MINNESOTA } \\
\hline WATERVILLE-WASECA & MINNEGASCO & LE SUEUR & 1996 & $\mathrm{x}$ & & AQUIFER \\
\hline \multicolumn{7}{|l|}{ MISSISSIPPI } \\
\hline EMINENCE EXP PHASE 2 & TRANSCO & COVINGTON & 1994 & $x$ & CP90-2230 & SALT DOME \\
\hline EMINENCE EXP PHASE 2 & TRANSCO & COVINGTON & 1995 & $\mathrm{x}$ & CP90-2230 & SALT DOME \\
\hline HATTIESBURG PHASE 2 & $\begin{array}{l}\text { HATTIESBURG GAS } \\
\text { STORAGE }\end{array}$ & FORREST & 1995 & $x$ & CP93-69 & SALT DOME \\
\hline MS-1 PHASE 1,2 & TEJAS POWER CORP & COPIAH & 1995 & & CP92-586 & SALT DOME \\
\hline MS-1 PHASE 3,4 & TEJAS POWER CORP & COPIAH & 1996 & $\mathrm{x}$ & CP92-586 & SALT DOME \\
\hline MS-1 PHASE 5 & TEJAS POWER CORP & COPIAH & 1997 & $x$ & CP92-586 & SALT DOME \\
\hline PETAL & PETAL GAS/CHEVRON & FORREST & 1994 & & CP93-69 & SALT DOME \\
\hline \multicolumn{7}{|l|}{ MONTANA } \\
\hline BAKER EXPANSION & WILLISTON BASIN & FALLON & 1994 & $x$ & CP93-285 & DEPL FIELD \\
\hline \multicolumn{7}{|l|}{ NEW YORK } \\
\hline AVOCA PHASE 1 & J. MAKOWSKI \& ASSOC. & STEUBEN & 1996 & & & SALT BED \\
\hline AVOCA PHASE 2 & J. MAKOWSKI \& ASSOC. & STEUBEN & 1997 & $x$ & CP94-161 & SALT BED \\
\hline AVOCA PHASE 3 & J. MAKOWSKI \& ASSOC. & STEUBEN & 1998 & $x$ & CP94-161 & SALT BED \\
\hline CAYUTA PHASE 1 & BOWDOIN STORAGE & SCHUYLER & 1996 & & & SALT BED \\
\hline CAYUTA PHASE 2 & BOWDOIN STORAGE & SCHUYLER & 1997 & $x$ & & SALT BED \\
\hline CAYUTA PHASE 3 & BOWDOIN STORAGE & SCHUYLER & 1998 & $x$ & & SALT BED \\
\hline LAUREL FIELDS-ALLEGANY & NATIONAL FUEL GAS & CATTARAUGUS & 1996 & $x$ & CP90-2086 & DEPL FIELD \\
\hline SENECA LAKE & NGE ENTERPRISES & SENECA & 1996 & & & SALT DOME \\
\hline THOMAS CORNERS & ARLINGTON STORAGE & STEUBEN & 1995 & $x$ & CP95-119 & DEPL FIELD \\
\hline WATKINS GLEN & $\begin{array}{l}\text { ANR STORAGE, NGE } \\
\text { ENTERPRISES }\end{array}$ & SCHUYLER & 1995 & & & SALT DOME \\
\hline
\end{tabular}


Table B3. Proposed Underground Storage by State, 1994-1999 (Continued)

\begin{tabular}{|c|c|c|c|c|c|c|}
\hline \multirow[b]{2}{*}{ Project Name/State } & \multicolumn{3}{|c|}{$\begin{array}{c}\text { Capacity } \\
\text { (billion cubic feet) }\end{array}$} & \multicolumn{2}{|c|}{$\begin{array}{c}\text { Capacity } \\
\text { (MMcf per day) }\end{array}$} & \multirow[b]{2}{*}{$\begin{array}{c}\text { Total Cost } \\
\text { (Thousand \$) }\end{array}$} \\
\hline & Total & Base Gas & $\begin{array}{l}\text { Working } \\
\text { Gas }\end{array}$ & Withdrawal & Injection & \\
\hline JEFFERSON ISLAND & 4.70 & 1.70 & 3.00 & 300 & 150 & so \\
\hline JENNINGS SALT DOME & 6.00 & 1.90 & 4.10 & 1200 & 150 & $\$ 56,000$ \\
\hline LA-1 PHASE 3, 4 & 6.20 & 2.20 & 4.00 & 400 & 200 & $\$ 18,000$ \\
\hline LA-1 PHASE 5, 6 & 6.20 & 2.20 & 4.00 & 400 & 200 & $\$ 12,000$ \\
\hline LA-1/EGAN PHASE 1, 2 & 6.70 & 2.20 & 4.50 & 400 & 150 & $\$ 37,000$ \\
\hline NAPOLEONVILLE PHASE 1 & 8.30 & 3.70 & 4.60 & 400 & 200 & $\$ 45,000$ \\
\hline NAPOLEONVILLE PHASE 2 & 10.00 & 3.00 & 7.00 & 600 & 300 & $\$ 33,750$ \\
\hline OUACHITA RIVER & 40.50 & 13.50 & 27.00 & 550 & 250 & $\$ 80,000$ \\
\hline SULPHUR MINES & 13.55 & 5.55 & 8.00 & 400 & 150 & $\$ 65,000$ \\
\hline TOTALS: Projects $=11$ & 174.15 & 65.95 & 108.20 & 5,400 & 2,223 & 446,750 \\
\hline \multicolumn{7}{|l|}{ MICHIGAN } \\
\hline GRANDS LACS & 3.00 & 0.00 & 3.00 & 150 & 0 & $\$ 100,000$ \\
\hline KAL.KASKA 30 & 22.00 & 5.00 & 17.00 & 200 & 150 & $\$ 50,000$ \\
\hline LEE 8 & 3.80 & 3.80 & 0.00 & 0 & 0 & \$o \\
\hline LIVINGSTON EXPANSION & 0.80 & 0.00 & 0.80 & 0 & 0 & $\$ 1,000$ \\
\hline WASHINGTON TOWNSHIP & 42.00 & 42.00 & 0.00 & 800 & 0 & $\$ 120,000$ \\
\hline TOTALS: Projects $=\mathbf{5}$ & 71.60 & 50.80 & 20.80 & 1.150 & 150 & 271,000 \\
\hline \multicolumn{7}{|l|}{ MINNESOTA } \\
\hline WATERVILLE-WASECA & 2.00 & 0.80 & 1.20 & 0 & 0 & $\$ 2,000$ \\
\hline TOTALS: Projects $=1$ & 2.00 & 0.80 & 1.20 & $\mathbf{0}$ & 0 & $\$ 2,000$ \\
\hline \multicolumn{7}{|l|}{ MISSISSIPPI } \\
\hline EMINENCE EXP PHASE 2 & 4.64 & 1.72 & 2.92 & 200 & 0 & $\$ 10,152$ \\
\hline EMINENCE EXP PHASE 2 & 4.64 & 1.72 & 2.92 & 0 & 0 & $\$ 10,152$ \\
\hline HATTIESBURG PHASE 2 & 3.16 & 0.96 & 2.20 & 220 & 40 & $\$ 20,000$ \\
\hline MS-1 PHASE 1, 2 & 4.20 & 1.20 & 3.00 & 300 & 280 & $\$ 60,000$ \\
\hline MS-1 PHASE 3,4 & 4.20 & 1.20 & 3.00 & 300 & 0 & $\$ 25,000$ \\
\hline MS-1 PHASE 5 & 4.20 & 1.20 & 3.00 & 300 & 280 & $\$ 15,000$ \\
\hline PETAL & 5.00 & 1.80 & 3.20 & 320 & 160 & $\$ 30,000$ \\
\hline TOTALS: Projects $=7$ & 30.04 & 9.80 & 20.24 & 1,640 & 760 & 170,304 \\
\hline \multicolumn{7}{|l|}{ MONTANA } \\
\hline BAKER EXPANSION & 0.00 & 0.00 & 0.00 & 40 & 20 & $\$ 7,312$ \\
\hline TOTALS: Projects $=1$ & 0.00 & 0.00 & 0.00 & 40 & 20 & $\$ 7,312$ \\
\hline \multicolumn{7}{|l|}{ NEW YORK } \\
\hline AVOCA PHASE 1 & 2.96 & 0.96 & 2.00 & 320 & 160 & $\$ 49,000$ \\
\hline AVOCA PHASE 2 & 2.30 & 0.30 & 2.00 & 100 & 50 & $\$ 5,600$ \\
\hline AVOCA PHASE 3 & 1.24 & 0.24 & 1.00 & 80 & 40 & $\$ 4,600$ \\
\hline CAYUTA PHASE 1 & 4.00 & 0.80 & 3.20 & 320 & 160 & $\$ 42,000$ \\
\hline CAYUTA PHASE 2 & 2.50 & 0.50 & 2.00 & 100 & 50 & $\$ 6,600$ \\
\hline CAYUTA PHASE 3 & 1.30 & 0.30 & 1.00 & 80 & 40 & $\$ 6,600$ \\
\hline LAUREL FIELDS-ALLEGANY & 15.30 & 9.30 & 6.00 & 60 & 40 & $\$ 48,600$ \\
\hline SENECA LAKE & 0.80 & 0.00 & 0.80 & 80 & 20 & $\$ 59,000$ \\
\hline THOMAS CORNERS & 7.70 & 2.70 & 5.00 & 50 & 33 & $\$ 28,000$ \\
\hline WATKINS GLEN & 2.00 & 0.00 & 2.00 & 200 & $\mathbf{0}$ & $\$ 0$ \\
\hline TOTALS: Projects $=10$ & 40.10 & 15.10 & 25.00 & 1,390 & 593 & 250,000 \\
\hline
\end{tabular}




\begin{tabular}{|c|c|c|c|c|c|c|}
\hline Project Name/State & Operator & County & $\begin{array}{l}\text { Year in } \\
\text { Service }\end{array}$ & $\begin{array}{c}\text { Expansion } \\
\text { Project? } \\
\text { (X=Yes) }\end{array}$ & $\begin{array}{l}\text { FERC } \\
\text { Docket } \\
\text { Number }\end{array}$ & $\begin{array}{l}\text { Reservoir } \\
\text { Type }\end{array}$ \\
\hline \multicolumn{7}{|l|}{ OKLAHOMA } \\
\hline MANCHESTER & $\begin{array}{l}\text { WILLIAMS BROTHERS } \\
\text { ENGINEERING }\end{array}$ & GRANT & 1995 & & & DEPL FIELD \\
\hline OKFUSKEE & UNIGAS CORP & OKFUSKEE & 1994 & & & DEPL FIELD \\
\hline \multicolumn{7}{|l|}{ PENNSYLVANIA } \\
\hline LAUREL FIELDS-CALLEN RUN & NATIONAL FUEL GAS & JEFFERSON & 1996 & & CP90-2086 & DEPL FIELD \\
\hline RIVERSIDE & $\begin{array}{l}\text { RIVERSIDE GAS } \\
\text { STORAGE }\end{array}$ & GREENE & 1995 & & CP94-292 & DEPL FIELD \\
\hline \multicolumn{7}{|l|}{ TEXAS } \\
\hline ATKINSON GAS STORAGE & KEBO OIL & LIVE OAK & 1994 & & & DEPL FIELD \\
\hline BETHEL PHASE 3 & LONE STAR GAS & ANDERSON & 1995 & $x$ & & SALT DOME \\
\hline HILBIG & $\begin{array}{l}\text { LOWER COLO. RIVER } \\
\text { AUTH }\end{array}$ & BASTROP & 1994 & & & DEPL FIELD \\
\hline LOOP PHASE 2 & $\begin{array}{l}\text { AMERICAN GAS } \\
\text { STORAGE }\end{array}$ & GAINES & 1994 & $x$ & & SALT BED \\
\hline LOOP PHASE 3 & $\begin{array}{l}\text { AMERICAN GAS } \\
\text { STORAGE }\end{array}$ & GAINES & 1995 & $x$ & & SALT BED \\
\hline MARKHAM (CAVERN \#2) & COASTLINE(UTTCO) & MATAGORDA & 1994 & $x$ & & SALT DOME \\
\hline MOSS BLUFF PHASE 3 & TEJAS POWER CORP & LIBERTY & 1995 & $x$ & & SALT DOME \\
\hline NICHOLS STATION PLANT & SW PUBLIC SERVICE & & 1994 & & & SALT DOME \\
\hline NORTH FELMAC & $\begin{array}{l}\text { AMERICAN GAS } \\
\text { STORAGE }\end{array}$ & GAINES & 1994 & & & DEPL FIELD \\
\hline SALADO GAS STORAGE & $\begin{array}{l}\text { AMERICAN GAS } \\
\text { STORAGE }\end{array}$ & GAINES & 1994 & & & SALT BED \\
\hline $\begin{array}{l}\text { SPINDLETOP } \\
\text { (SABINE-CAVERN }\end{array}$ & $\begin{array}{l}\text { SABINE GAS } \\
\text { TRANSMISSION }\end{array}$ & JEFFERSON & 1995 & $x$ & & SALT DOME \\
\hline $\begin{array}{l}\text { SPINDLETOP } \\
\text { SABINE-CAVERN }\end{array}$ & $\begin{array}{l}\text { SABINE GAS } \\
\text { TRANSMISSION }\end{array}$ & JEFFERSON & 1994 & $x$ & & SALT DOME \\
\hline SPINDLETOP (WINNIE P L) & WINNIE PIPELINE & JEFFERSON & 1997 & $x$ & & SALT DOME \\
\hline STRATTON RIDGE (AMOCO) & AMOCO & BRAZORIA & 1994 & $x$ & & SALT DOME \\
\hline STRATTON RIDGE (MG) & MG STORAGE CORP & BRAZORIA & 1994 & & & SALT DOME \\
\hline \multicolumn{7}{|l|}{ UTAH } \\
\hline CLAY BASIN EXPANSION & QUESTAR & DAGGETT & 1994 & $x$ & CP93-409 & DEPL FIELD \\
\hline \multicolumn{7}{|l|}{ VIRGINIA } \\
\hline SALTVILLE & $\begin{array}{l}\text { TENNECO ENERGY } \\
\text { RESNIRGINIA }\end{array}$ & SMYTH & 1995 & & & SALT DOME \\
\hline \multicolumn{7}{|l|}{ WYOMING } \\
\hline ELK BASIN RETROFIT & WILLISTON BASIN & PARK & 1994 & $\mathrm{x}$ & CP93-283 & DEPL FIELD \\
\hline
\end{tabular}


Table B3. Proposed Underground Storage by State, 1994-1999 (Continued)

\begin{tabular}{|c|c|c|c|c|c|c|}
\hline \multirow[b]{2}{*}{ Project Name/State } & \multicolumn{3}{|c|}{$\begin{array}{c}\text { Capacity } \\
\text { (billion cubic feet) }\end{array}$} & \multicolumn{2}{|c|}{$\begin{array}{c}\text { Capacity } \\
\text { (MMcf per day) }\end{array}$} & \multirow[b]{2}{*}{$\begin{array}{c}\text { Total Cost } \\
\text { (Thousand \$) }\end{array}$} \\
\hline & Total & Base Gas & $\begin{array}{l}\text { Working } \\
\text { Gas }\end{array}$ & Withdrawal & Injection & \\
\hline \multicolumn{7}{|l|}{ OKLAHOMA } \\
\hline MANCHESTER & 18.50 & 3.50 & 15.00 & 250 & 100 & $\$ 30,000$ \\
\hline OKFUSKEE & 45.00 & 15.00 & 30.00 & 600 & 200 & $\$ 70,000$ \\
\hline TOTALS: Projects $=2$ & 63.50 & 18.50 & 45.00 & 850 & 300 & 100,000 \\
\hline \multicolumn{7}{|l|}{ PENNSYLVANIA } \\
\hline LAUREL FIELDS-CALLEN RUN & 24.90 & 12.80 & 12.10 & 130 & 50 & $\$ 76,000$ \\
\hline RIVERSIDE & 5.64 & 2.54 & 3.10 & 48 & 48 & $\$ 24,000$ \\
\hline TOTALS: Projects $=2$ & 30.54 & 15.34 & 15.20 & 178 & 98 & 100,000 \\
\hline \multicolumn{7}{|l|}{ TEXAS } \\
\hline ATKINSON GAS STORAGE & 39.00 & 11.00 & 28.00 & 400 & 300 & $\$ 23,000$ \\
\hline BETHEL PHASE 3 & 5.00 & 1.50 & 3.50 & 200 & 0 & $\$ 29,000$ \\
\hline HILBIG & 4.80 & 1.80 & 3.00 & 60 & 30 & $\$ 15,000$ \\
\hline LOOP PHASE 2 & 2.00 & 1.00 & 1.00 & 200 & 100 & $\$ 2,500$ \\
\hline LOOP PHASE 3 & 2.00 & 1.00 & 1.00 & 200 & 100 & $\$ 2,500$ \\
\hline MARKHAM (CAVERN \#2) & 4.50 & 1.30 & 3.20 & 250 & 90 & $\$ 11,700$ \\
\hline MOSS BLUFF PHASE 3 & 6.00 & 2.00 & 4.00 & 300 & 0 & $\$ 17,000$ \\
\hline NICHOLS STATION PLANT & 4.20 & 1.20 & 3.00 & 300 & 150 & $\$ 13,000$ \\
\hline NORTH FELMAC & 5.60 & 0.00 & 5.60 & 140 & 150 & so \\
\hline SALADO GAS STORAGE & 3.00 & 0.00 & 3.00 & 260 & 0 & so \\
\hline SPINDLETOP (SABINE-CAVERN & 4.70 & 1.90 & 2.80 & 120 & 0 & $\$ 0$ \\
\hline SPINDLETOP (SABINE-CAVERN & 5.40 & 2.50 & 2.90 & 240 & 600 & $\$ 0$ \\
\hline SPINDLETOP (MINNIE P L) & 10.30 & 0.00 & 10.30 & 1000 & 0 & $\$ 46,000$ \\
\hline STRATTON RIDGE (AMOCO) & 1.40 & 0.40 & 1.00 & 100 & 0 & $\$ 8,300$ \\
\hline STRATTON RIDGE (MG) & 12.50 & 5.30 & 7.20 & 250 & 100 & \$o \\
\hline TOTALS: Projects $=15$ & 110.40 & 30.90 & 79.50 & 4,020 & 1,620 & 168,000 \\
\hline \multicolumn{7}{|l|}{ UTAH } \\
\hline CLAY BASIN EXPANSION & 26.30 & 11.10 & 15.20 & 258 & 130 & $\$ 49,600$ \\
\hline TOTALS: Projects $=1$ & 26.30 & 11.10 & 15.20 & 258 & 130 & $\$ 49,600$ \\
\hline \multicolumn{7}{|l|}{ VIRGINIA } \\
\hline SALTVILLE & 0.25 & 0.00 & 0.25 & 25 & 0 & \$o \\
\hline TOTALS: Projects $=1$ & 0.25 & 0.00 & 0.25 & 25 & $\mathbf{0}$ & so \\
\hline \multicolumn{7}{|l|}{ WYOMING } \\
\hline ELK BASIN RETROFIT & 0.00 & 0.00 & 0.00 & 55 & 27 & $\$ 3,692$ \\
\hline TOTALS: Projects $=1$ & 0.00 & 0.00 & 0.00 & 55 & 27 & $\$ 3,692$ \\
\hline U.S. TOTAL & & & & 20,746 & 7.804 & $\$ 2,166,834$ \\
\hline
\end{tabular}

MMcf = Million cubic feet.

Note: Two liquefied natural gas storage projects (one new, one expansion) have also been proposed by Cove Point LNG at Cove Point, Maryland, which would add 4 Bcf working gas capacity, 1,000 MMcf per day withdrawal capacity, and 15 MMcf per day injection capacity. Totals may not equal sum of components because of independent rounding.

Source: Energy Information Administration, Office of Oil and Gas, "Proposed Natural Gas Storage Projects," data base as of October 31, 1994, based on Federal Energy Regulatory Commission filings and information from various industry news sources. 

Appendix C

Revisions to Working Gas Storage Data 


\section{Appendix C}

\section{Revisions to Working Gas Storage Data}

An underground storage site is described by its total capacity (the total volume of gas that can be stored in the facility), its base gas or volume of gas that remains in the facility at all times, and its working gas capacity, which is the difference between the first two measures (total capacity minus base gas). Base gas is the amount of gas that supports the working gas by providing pressure to enable the working gas to be withdrawn at an acceptable rate. Working gas is the amount of gas in the site that is available for withdrawal to serve customer or system needs. Only when the storage site is completely full does the working gas reach the working gas capacity.

Each month gas is injected into and withdrawn from an underground facility, either increasing or decreasing the working gas. In theory, the level of working gas cannot exceed the working gas capacity nor may it drop below zero. In practice however, it is possible to exceed the working gas capacity by overpressurization, and it is possible to go below zero by withdrawing base gas. The determination of base gas has some degree of flexibility, depending on what level is determined necessary to maintain a desired withdrawal rate.

Each month, on the Energy Information Administration's Form EIA-191, "Underground Gas Storage Report," storage operators report their current estimates of total capacity, base gas, and working gas, as well as their estimates of gas withdrawn and injected that month. Base gas levels can fluctuate slightly because of factors such as migration losses, but these are usually very small changes. Base gas will also change if a site is expanded, and will increase as a new site or an aquifer is pressurized. Otherwise, base gas is essentially a constant. Similarly, the total capacity of a reservoir is not expected to change. Base gas thus represents a financial cost that is not recoverable because the gas is ordinarily not withdrawn and sold until the site is abandoned.

However, between January 1992 and December 1993, over one-quarter (118) of all facilities revised their base gas levels overall by more than 3 percent, thus also changing the working gas capacities. An additional 33 sites reported withdrawals from base gas. The largest changes to base gas came just prior to the 1993-94 heating season. The total base gas revisions were substantial, representing a net change of more than 250 billion cubic feet, or 6.3 percent, from levels a year earlier. Comparatively, between the 1990-91 and 199192 heating seasons, base gas levels were revised upward by only half that amount. In prior years, revisions were less than 1 percent annually.

In effect, existing working gas capacity was downsized during 1992 and 1993, whereby a portion of working gas was shifted to the base gas category for accounting purposes. The 3percent increase (104 billion cubic feet) in base gas levels during 1992 reflect changes in the natural gas marketplace as a result of open-access transportation programs. Columbia Gas Transmission, for instance, revised its base gas estimates at a number of its storage sites after a global settlement reached with its customers indicated that the customers wanted, and market demand indicated a need for, more peaking service, thus, a need for higher daily deliverability from storage. Columbia, therefore, increased its base gas at most of its storage sites to increase reservoir pressure and, consequently, deliverability. Penn-York Energy Corporation, in a separate settlement case before FERC, was permitted to increase its base gas at one of its major storage sites to compensate for gas lost over a period of time because of reservoir migration. The reclassification provided for cost recovery.

In 1993, most of the base gas reclassification resulted from the restructuring of storage operations by interstate pipeline companies to comply with the Federal Energy Regulatory Commission's (FERC) Order 636. Before the reclassifications, these operators had more capacity classified as working gas than could realistically be withdrawn during a heating season or refilled during a nonheating season. Therefore, under restructuring, they revised their estimates to present a more representative picture of storage capabilities to their customers. In most instances, these reclassifications are subject to final approval in the pipeline company's ongoing rate case. ${ }^{48}$

\section{Impacts on Analyses}

Because base gas levels were revised only at some sites and at different time periods, comparisons of certain storage data cannot be made. For example, comparisons of working gas

\footnotetext{
${ }^{48}$ The major companies that reported revised base gas levels in response to the FERC ruling were: Natural Gas Pipeline Company of America, KN Interstate Gas Co, Southern Natural Gas Co, Equitrans, Inc., and El Paso Natural Gas Co.
} 
capacity or percentage of working gas filled in September 1992 versus September 1994 would not be valid because base gas is a part of the calculations.

Another difficulty in data comparisons is that the reported working gas levels are often changed from one month to the next. Many respondents (storage operators) to Form EIA-191 re-estimate storage levels from time to time, so that working gas for the reported month is not the sum of last month's total plus injections and minus withdrawals. From 1991 through 1994, working gas levels had been re-estimated for more than 96 percent of the storage sites.

The approach taken to resolve some of these data and analyses difficulties was to recalculate working gas capacity and working gas levels using the following two assumptions:
1. The most recent estimates of base gas are also historically valid as the most accurate.

2. Estimates of monthly injections and withdrawals are accurate.

The monthly data for each storage site were sorted beginning with the most recent data. From that starting point, injections and withdrawals were systematically added and subtracted to produce new monthly working gas levels. The most recent capacity and base gas values were also carried back through the previous months. These new calculations produced little difference in the 1994 data but increasing difference in earlier years. Table $\mathrm{Cl}$ summarizes the calculations by month for all storage sites, showing the difference in base gas increasing to 8 percent by early 1991 , and the difference in percent filled (ratio of working gas to working gas capacity) increasing to 6 percent. 
Table C1. Underground Gas Storage Volumes

(Volumes in Billion Cubic Feet)

\begin{tabular}{|c|c|c|c|c|c|c|c|c|c|}
\hline \multirow{2}{*}{ Year/Month } & \multicolumn{3}{|c|}{ Base Gas } & \multicolumn{2}{|c|}{ Working Gas Capacity } & \multicolumn{2}{|c|}{ Working Gas } & \multicolumn{2}{|c|}{ Percent Full } \\
\hline & Reported & Adjusted & $\begin{array}{l}\text { Percent } \\
\text { Difference }\end{array}$ & Reported & Adjusted & Reported & Adjusted & Reported & Adjusted \\
\hline \multicolumn{10}{|l|}{1991} \\
\hline $\begin{array}{l}\text { January } \\
\text { February } \\
\text { March } \\
\text { April } \\
\text { May } \\
\text { June } \\
\text { July } \\
\text { August } \\
\text { September } \\
\text { October } \\
\text { November } \\
\text { December }\end{array}$ & $\begin{array}{l}3,984 \\
3,996 \\
3,985 \\
3,997 \\
4,030 \\
4,039 \\
4,043 \\
4,048 \\
4,049 \\
4,051 \\
4,052 \\
4,056\end{array}$ & $\begin{array}{l}4,298 \\
4,299 \\
4,299 \\
4,299 \\
4,299 \\
4,299 \\
4,299 \\
4,299 \\
4,301 \\
4,301 \\
4,302 \\
4,304\end{array}$ & $\begin{array}{l}8 \\
8 \\
8 \\
8 \\
7 \\
6 \\
6 \\
6 \\
6 \\
6 \\
6 \\
6\end{array}$ & $\begin{array}{l}4,042 \\
3,915 \\
3,923 \\
3,953 \\
3,850 \\
3,846 \\
3,861 \\
3,862 \\
3,872 \\
3,868 \\
3,840 \\
3,862\end{array}$ & $\begin{array}{l}3,582 \\
3,582 \\
3,582 \\
3,582 \\
3,582 \\
3,582 \\
3,582 \\
3,582 \\
3,589 \\
3,589 \\
3,590 \\
3,599\end{array}$ & $\begin{array}{l}2,328 \\
2,039 \\
1,890 \\
2,020 \\
2,255 \\
2,533 \\
2,750 \\
2,957 \\
3,180 \\
3,347 \\
3,127 \\
2,809\end{array}$ & $\begin{array}{l}1,966 \\
1,685 \\
1,525 \\
1,650 \\
1,911 \\
2,183 \\
2,396 \\
2,596 \\
2,811 \\
2,959 \\
2,757 \\
2,440\end{array}$ & $\begin{array}{l}58 \\
52 \\
48 \\
51 \\
59 \\
66 \\
71 \\
77 \\
82 \\
87 \\
81 \\
73\end{array}$ & $\begin{array}{l}55 \\
47 \\
43 \\
46 \\
53 \\
61 \\
67 \\
73 \\
78 \\
82 \\
77 \\
68\end{array}$ \\
\hline \multicolumn{10}{|l|}{1992} \\
\hline $\begin{array}{l}\text { January } \\
\text { February } \\
\text { March } \\
\text { April } \\
\text { May } \\
\text { June } \\
\text { July } \\
\text { August } \\
\text { September } \\
\text { October } \\
\text { November } \\
\text { December }\end{array}$ & $\begin{array}{l}4,038 \\
4,038 \\
4,032 \\
4,022 \\
4,025 \\
4,027 \\
4,061 \\
4,058 \\
4,057 \\
4,061 \\
4,054 \\
4,022\end{array}$ & $\begin{array}{l}4,314 \\
4,314 \\
4,314 \\
4,314 \\
4,314 \\
4,314 \\
4,333 \\
4,333 \\
4,333 \\
4,335 \\
4,335 \\
4,335\end{array}$ & $\begin{array}{l}7 \\
7 \\
7 \\
7 \\
7 \\
7 \\
7 \\
7 \\
7 \\
7 \\
7 \\
8\end{array}$ & $\begin{array}{l}3,888 \\
3,887 \\
3,893 \\
3,904 \\
3,901 \\
3,898 \\
3,890 \\
3,892 \\
3,893 \\
3,892 \\
3,899 \\
3,931\end{array}$ & $\begin{array}{l}3,611 \\
3,611 \\
3,611 \\
3,611 \\
3,611 \\
3,611 \\
3,617 \\
3,617 \\
3,617 \\
3,617 \\
3,617 \\
3,617\end{array}$ & $\begin{array}{l}2,203 \\
1,825 \\
1,533 \\
1,562 \\
1,837 \\
2,141 \\
2,448 \\
2,749 \\
3,031 \\
3,211 \\
3,042 \\
2,585\end{array}$ & $\begin{array}{l}1,913 \\
1,525 \\
1,225 \\
1,243 \\
1,520 \\
1,843 \\
2,149 \\
2,458 \\
2,756 \\
2,939 \\
2,759 \\
2,268\end{array}$ & $\begin{array}{l}57 \\
47 \\
39 \\
40 \\
47 \\
55 \\
63 \\
71 \\
78 \\
83 \\
78 \\
66\end{array}$ & $\begin{array}{l}53 \\
42 \\
34 \\
34 \\
42 \\
51 \\
59 \\
68 \\
76 \\
81 \\
76 \\
63\end{array}$ \\
\hline \multicolumn{10}{|l|}{1993} \\
\hline $\begin{array}{l}\text { January } \\
\text { February } \\
\text { March } \\
\text { April } \\
\text { May } \\
\text { June } \\
\text { July } \\
\text { August } \\
\text { September } \\
\text { October } \\
\text { November } \\
\text { December }\end{array}$ & $\begin{array}{l}4,271 \\
4,248 \\
4,228 \\
4,239 \\
4,254 \\
4,264 \\
4,263 \\
4,270 \\
4,261 \\
4,321 \\
4,342 \\
4,340\end{array}$ & $\begin{array}{l}4,337 \\
4,338 \\
4,336 \\
4,336 \\
4,336 \\
4,336 \\
4,336 \\
4,336 \\
4,329 \\
4,329 \\
4,336 \\
4,338\end{array}$ & $\begin{array}{l}2 \\
2 \\
3 \\
2 \\
2 \\
2 \\
2 \\
2 \\
2 \\
0 \\
0 \\
0\end{array}$ & $\begin{array}{l}3,692 \\
3,717 \\
3,733 \\
3,722 \\
3,707 \\
3,697 \\
3,698 \\
3,691 \\
3,684 \\
3,627 \\
3,661 \\
3,669\end{array}$ & $\begin{array}{l}3,620 \\
3,621 \\
3,618 \\
3,618 \\
3,618 \\
3,618 \\
3,618 \\
3,618 \\
3,624 \\
3,627 \\
3,669 \\
3,673\end{array}$ & $\begin{array}{l}1,818 \\
1,293 \\
1,017 \\
1,108 \\
1,512 \\
1,883 \\
2,229 \\
2,537 \\
2,862 \\
2,953 \\
2,771 \\
2,329\end{array}$ & $\begin{array}{r}1,713 \\
1,163 \\
857 \\
968 \\
1,395 \\
1,763 \\
2,104 \\
2,415 \\
2,733 \\
2,884 \\
2,715 \\
2,275\end{array}$ & $\begin{array}{l}49 \\
35 \\
27 \\
30 \\
41 \\
51 \\
60 \\
69 \\
78 \\
81 \\
76 \\
63\end{array}$ & $\begin{array}{l}47 \\
32 \\
24 \\
27 \\
39 \\
49 \\
58 \\
67 \\
75 \\
80 \\
74 \\
62\end{array}$ \\
\hline 1994 & & & & & & $\cdot$ & & & \\
\hline $\begin{array}{l}\text { January } \\
\text { February } \\
\text { March } \\
\text { April } \\
\text { May } \\
\text { June } \\
\text { July } \\
\text { August } \\
\text { September } \\
\text { October } \\
\text { November }\end{array}$ & $\begin{array}{l}4,344 \\
4,338 \\
4,344 \\
4,347 \\
4,353 \\
4,350 \\
4,353 \\
4,353 \\
4,351 \\
4,351 \\
4,351\end{array}$ & $\begin{array}{l}4,351 \\
4,351 \\
4,351 \\
4,351 \\
4,351 \\
4,351 \\
4,351 \\
4,351 \\
4,351 \\
4,351 \\
4,351\end{array}$ & $\begin{array}{l}0 \\
0 \\
0 \\
0 \\
0 \\
0 \\
0 \\
0 \\
0 \\
0 \\
0\end{array}$ & $\begin{array}{l}3,692 \\
3,698 \\
3,692 \\
3,689 \\
3,683 \\
3,686 \\
3,687 \\
3,687 \\
3,689 \\
3,689 \\
3,689\end{array}$ & $\begin{array}{l}3,685 \\
3,685 \\
3,685 \\
3,685 \\
3,685 \\
3,685 \\
3,688 \\
3,688 \\
3,688 \\
3,688 \\
, 688\end{array}$ & $\begin{array}{r}1,572 \\
1,085 \\
952 \\
1,165 \\
1,548 \\
1,890 \\
2,267 \\
2,600 \\
2,904 \\
3,067 \\
2,970 \\
\end{array}$ & $\begin{array}{r}1,556 \\
1,063 \\
931 \\
1,143 \\
1,535 \\
1,878 \\
2,258 \\
2,592 \\
2,906 \\
3,067 \\
2,970 \\
\end{array}$ & $\begin{array}{l}43 \\
29 \\
26 \\
32 \\
42 \\
51 \\
61 \\
71 \\
79 \\
83 \\
81 \\
\end{array}$ & $\begin{array}{l}42 \\
29 \\
25 \\
31 \\
42 \\
51 \\
61 \\
70 \\
79 \\
83 \\
81 \\
\end{array}$ \\
\hline
\end{tabular}

Note: These data exclude four storage fields included in Figure 1 and Table A1 that are not reported on EIA-191.

Source: Energy Information Administration (EIA). Reported: EIA-191, "Underground Gas Storage Report." Adjusted: Office of Oil and Gas. 

Appendix D

Regression

Analysis Results 



\title{
Appendix D
}

\section{Regression Analysis Results}

This appendix presents summary statistics and other findings for the regression analyses reported in Chapter 2. Background information for understanding the relationships estimated is included in the main body of the text and references to the data sources are included in source notes to the figures in the text.

\section{Spot Prices and Monthly Storage Needs}

\author{
(Pages 11 - 14)
}

\section{Specification and Estimation}

The first regression analysis presented in Chapter 2 deals with the relationship between the spot price of gas at the beginning of the month (PG) and the level of gas in storage at the end of the previous month (GS) relative to expected consumption (EC) or deliveries of gas for the month.[1,2] EC is measured by actual total consumption for a month in the previous year. PG is represented by the price of gas at the Henry Hub in Louisiana, which is the reference price for gas exchanges in the United States and Canada. This price largely represents exchanges of gas negotiated at the close of the previous month during a period called bid week when contracts for guaranteed deliveries of gas for the month are signed (for a discussion of spot and futures prices see [3-7]). An appealing characteristic of EIA storage or inventory data is that it represents inventories at the end of the month. Moreover, non-EIA price data represent prices negotiated at the end of the month for deliveries in the next month, and EIA consumption data represent consumption throughout the month. The temporal characteristics of these data are particularly appropriate for examining the relationship between price and inventories. For most other commodities the inventory and price data need to be adjusted prior to any econometric analysis.

Large values for GS relative to EC (GS/EC) are expected to be associated with low values for PG because large values for GS/EC indicate that supplies of gas in storage are plentiful relative to expected deliveries. When the regression equation is estimated, the following results are obtained (standard errors are reported in parenthesis followed by the coefficient of determination, $R^{2}$, and the value for the Durbin-Watson test, DW):

$\mathrm{PG}=5.12-1.09 \mathrm{GS} / \mathrm{EC}$

$(0.911)(0.287)$

$\mathrm{R}^{2}=0.59, \mathrm{DW}=1.78, \mathrm{n}=12$ (number of data points for storage at the end of January, February, and March for the years 1991-1994).

\section{Evaluation}

The size of the standard errors relative to the size of the coefficients in equation 1 indicates that the coefficients are significantly different from zero. The coefficient of determination $\left(\mathrm{R}^{2}\right)$ indicates that 59 percent of the variation in $P G$ is associated with the variation in GS/EC. The value for the Durbin-Watson (DW) test, while difficult to interpret with only $12(\mathrm{n}=12)$ observations, indicates that the errors terms in the model underlying equation 1 are independent (the assumption of a lack of first-order serial correlation could not be rejected). Because there are 6 negative residuals and 6 positive residuals and 6 runs of the residuals, a runs test on the residuals would indicate the same conclusion.[8] Examination of r-student values[9] indicates that there are no outlying observations. Examination of plots of the residuals against GS/EC also indicates that the assumption of a constant variance for the error terms is also not violated (copies are available from John H. Herbert, EIA). 


\title{
The Premium and Temperature Deviations
}

\author{
(Page 18)
}

\section{Specification and Estimation}

After examining the relationship between monthly spot prices and storage requirements, the next analysis focuses on daily data. The first objective is to examine how the value of having gas in storage might change between days. One way to estimate this value is to compute the difference between the daily spot price (DSP) for natural gas at the Henry Hub and the daily futures price (DFP) for natural gas for the nearby month contract (the contract that is next to terminate on the futures contract market). (Deliveries under a futures contract take place at the Henry Hub.) The difference in these prices is referred to as the "premium" in the main body of the text, and is denoted here as PR. It is also referred to as the basis by some, or the basis between the spot and futures prices at the Henry Hub to distinguish it from a locational basis. After gathering appropriate price information from spot and futures markets, it was observed that PR increased dramatically during the cold spell in mid-January 1994.

The magnitude of PR = DSP - DFP at different points in time is in part a consequence of the cost of storage and the cost of borrowing money. These costs are implicitly contained in DFP. The magnitude of $P R$ also reflects the convenience of having gas on hand (a marginal convenience value or yield). If the cost of storage (CS) and the cost of borrowing money (CM) is first subtracted from the futures price, then the difference between the spot price and this adjusted futures price is equal to the marginal convenience value or yield (CY) (i.e., DSP - $(D F P-C S-C M)=C Y$ or $P R+C S+C M=C Y$ ).

The degree to which several other variables might be related to PR is examined next. The first step is to examine previous investigations of the relationship between CY and other variables (early but still relevant investigations of CY include [10,11]). It is difficult, however, to draw lessons from these analyses because they examined commodities with a relatively constant demand throughout the year (for a theoretical discussion of distinguishing features of the economics of gas markets and gas storage see [12]). For such commodities it is possible simply to regress PR on storage levels after adjusting the futures price for the cost of storage and the cost of money. This adjustment is accomplished either directly by subtracting estimates of the cost of storage and the cost of money from the futures price prior to any regression analysis or indirectly by means of an appropriate variable in the regression equation. Even analysts that examined CY for heating oil[13,14], which exhibits a seasonal variability in consumption similar to natural gas but less pronounced, tended to ignore this variability in their analysis. Not surprisingly, they found it difficult to explain CY for heating oil using the methodology crafted by earlier analysts for commodities with relatively constant demand throughout the year. Thus, they used very indirect tests of CY. They examined whether the variability in an estimate of CY was significantly greater when storage levels were thought to be low. If the variability was significantly greater, they concluded that storage had a significant influence on $\mathrm{CY}$.

The demand for natural gas is not only highly variable throughout the year, but it is also strongly correlated with temperature during the wintertime because of the large amount of space-heating demand satisfied by natural gas furnaces.[15] When the temperature drops in the wintertime, demand for natural gas rises, which may put upward pressure on prices. Yet, the same temperature drop at different times has a much different significance for the gas industry. A $5^{\circ}$ drop from $30^{\circ}$ Fahrenheit $(F)$ at the beginning of January in New York has much less significance than the same occurrence in March, when it is less likely for temperatures to be that low. Thus, while absolute changes in temperature may be expected to influence the demand for gas, temperature changes compared to normal temperatures for the time period should have a more significant influence.

The storage part of the gas industry, in fact, organizes itself around normal temperatures and reasonable expectations of deviations from normal. It p!aces enough gas in storage, particularly in end-use market areas, to meet the expected demand associated with normal temperatures, as well as variations in demand that occur from daily deviations from normal temperature. Colder than normal temperatures may have a positive influence on price changes because prices are more likely to increase than decrease when temperatures fall below normal.

The temperature variable used in this analysis is:

$$
\mathrm{DT}_{\mathrm{t}}=N \mathrm{NT}_{\mathrm{t}}-\mathrm{T}_{\mathrm{t}}
$$


where $T_{t}$ is the temperature on day $t$ at a particular site (the average of the daily high and low temperatures at the site), and $N T_{t}$ is the normal temperature on day $t$ at the same site (the average of the long-term average high and low temperatures at the site). Thus, as temperatures fall below normal, the deviation in temperature, DT, is positive and increases. A positive relationship is expected between $P R_{1}$ and $D T_{i}$; that is, as $D T_{t}$ increases $\left(T_{t}\right.$ declines relative to $\left.N T_{t}\right), P R_{t}$ is expected to increase.

The variable $T$ is a reliable measure of daily temperatures at a site as long as a large drop in temperature does not occur at the beginning or close of a day. A further refinement of the analysis presented here would be to use hourly temperature data in order to adjust for such shifts. For example, if the temperature declines from $40^{\circ} \mathrm{F}$ to $12^{\circ} \mathrm{F}$ between $3 \mathrm{a} . \mathrm{m}$. and $5 \mathrm{a}$.m. and stays near $12^{\circ} \mathrm{F}$ throughout the day, it would probably be better to use the minimum temperature rather than the average of the high and low temperatures as an indicator of temperatures experienced during the day.

The values of DT used for this analysis are the average of DT for four cities that are distributed across the major natural gas space-heating region of the United States. The four cities are Kansas City, Missouri; Chicago, Illinois; Pittsburgh, Pennsylvania; and New York, New York. The temperature changes at these sites represent the temperature changes experienced by a large percentage of gas space-heating customers in the United States. Interestingly enough, data for several sites (Chicago and Pittsburgh in particular) give results similar to an average of the values at the four sites in terms of explaining PR.[16] These results follow from the interesting fact that temperature changes between days across locations in the eastern part of the United States tend to be correlated or dependent, while temperature changes between days at the same site tend to be uncorrelated or independent.

A previous analysis[17] found average monthly storage withdrawals to be highly correlated with average monthly declines in temperature. Therefore, prior to examining the relationship between the daily variables, PR and DT, the issue of whether DT is also a possible proxy variable for daily storage withdrawals was examined. The way that this issue was addressed is described next.

An estimate of weekly storage withdrawals was computed by taking the difference in the level of weekly working gas between weeks for the Consuming East Region as defined by the American Gas Association (AGA). This region includes the cities of Kansas City, Missouri; Chicago, Illinois; Pittsburgh, Pennsylvania and New York, New York. (These weekly data were first published by the AGA in December 1993). This should provide a reasonable estimate of withdrawals as long as there is only a modest amount of injections of gas into storage for the time period covered by the analysis. An examination of monthly EIA data indicate that storage injections were only 7 percent of withdrawals during January and February 1994. Weekly values for DT were obtained by taking the sum of the daily values for $\mathrm{DT}_{1}$ for the same 7-day period covered by the AGA weekly storage statistics. Then, the correlation coefficient for weekly values for DT and weekly values for storage withdrawals was computed. The correlation coefficient was found to be equal to 0.82 .

Given the strong relationship between weekly values of DT and the estimate of weekly storage withdrawals, $D T_{t}$ is used to approximate the behavior of daily storage withdrawals. When PR is regressed on DT, the following equation is estimated (standard errors are reported in parenthesis):

$$
\begin{aligned}
P R_{t}= & 0.184+0.0182 D T_{t} \\
& (0.042)(0.004)
\end{aligned}
$$

$R^{2}=0.37, n=38$ (the number of data points that covers the 38 trading days on the cash and futures market for the months of January and February 1994).

The estimated coefficients are statistically different from zero as indicated by the magnitude of the standard error relative to the magnitude of the estimated coefficient. In addition, 37 percent of the variability in $P R$ is explained by $D T\left(R^{2}=0.37\right)$. When a robust estimator (least absolute deviation[18]) is used to reestimate the relationship between PR and DT and to evaluate the influence of outlying observations on estimated results, it is found that the estimated coefficient for the intercept term (0.184) changes by only -0.017 and the coefficient for the variable DT (.0182) changes by only -0.007 . Thus, the coefficients are found to be stable and not much influenced by outlying observations. The value of $R^{2}$, however, increased to 0.51 .

Estimated results for equation 3 and the robust procedure are mentioned in the main body of the text. Another estimated equation, which is discussed next (equation 4), includes a time variable (TP). As a consequence of the examination of the residuals from this estimation, two additional equations (equations 5 and 6) were estimated. The results of these estimations appear in 
footnote 22 in the main text. A final equation was also estimated (equation 7) to evaluate the inclusion of a stock variable in the specification of the behavioral relationship underlying equation 6 . The results reported for this estimation are not reflected in the main text because this estimation was done for the primary purpose of evaluating the estimated results reported for equation 6 .

As previously stated, part of the difference between DSP and DFP is due to the cost of storing gas and the cost of borrowing money (the daily interest rate times the number of days over which the money is to be borrowed). The daily cost of having gas in storage, per MMBtu of gas acquired, is relatively constant from one day to the next because most storage rental space charges are based on long-term fixed price contracts. The cost of storage at a particular time is determined more by contract conventions than by market forces, although over time contract provisions may be changed to reflect market conditions. The interest rate is also relatively constant from one day to the next although interest rates did begin to increase during February 1994.

A time index variable (TP), which declines in value by one unit for each trading day as the termination of contract approaches, is used as a proxy variable to capture the cost of storage and the cost of money in the regression relationship. This proxy variable is used because estimates of the daily cost of storing gas are not generally available.

The variable TP declines in value as the last trading day of the futures market approaches because the cost of storage and the cost of money declines as the number of days to the termination of the contract declines. For example, in principle, if money is borrowed to purchase and store gas 20 days before the termination of the contract, the cost of money and the cost of storage is approximately 20 times as great as it would be if we borrowed money to purchase and store gas on the last day of trading of the futures contract. Thus, if there are 20 days to the termination of the contract, this variable takes on the value 20 , while if there is one day to termination, it takes on the value one.

The estimated equation with both DT and TP is (standard errors are reported in parenthesis):

$$
\begin{gathered}
\mathrm{PR}_{\mathrm{t}}=0.288+0.0184 \mathrm{DT} \mathrm{T}_{\mathrm{t}}-0.0070 \mathrm{TP}_{\mathrm{t}} \\
\begin{array}{c}
(0.078)(0.004) \\
(0.0043)
\end{array} \\
\mathrm{R}^{2}=0.40, \mathrm{n}=38
\end{gathered}
$$

Although the signs of all coefficients are consistent with expectations and the coefficient for DT is clearly significantly different from zero, examination of the residuals from the fitted equation reveals that the r-student values associated with observations for February 2nd and 3rd are particularly large at 4.1457 and 3.3694, respectively. Such large residuals may be due to erroneous data, a misspecified stochastic model, or a misspecified behavioral relationship.

\section{Misspecified Stochastic Model}

Large residuals can be viewed as a consequence of the error terms being generated by a distribution other than the normal distribution. This would be a distribution in which the chance of extreme values is greater than under a normal distribution. In situations where information is unavailable about the distribution of the error terms in the population, a robust estimator, such as a least absolute deviation (LAD) estimator, may be a better estimator than the ordinary least squares (OLS) estimator. The OLS estimator is inherently very sensitive to the distributional assumption, in that the value estimated for a coefficient is potentially very sensitive to outlying observations. LAD estimators, however, are less sensitive to the exact form of the distribution.

When the relationship between PR and DT and TP is reestimated using a LAD estimator, the following equation is estimated (standard errors are reported in parenthesis):

$$
\begin{gathered}
P R_{t}=0.316+0.0187 D T_{t}-0.0104 T P_{t} \\
(0.042)(0.0023) \quad(0.025) \\
R^{2}=0.69
\end{gathered}
$$




\section{Incompletely Specified Behavioral Equation}

Instead of using a robust estimator, another approach to determining an equation that better explains the behavior of PR is to use a dummy variable for the outlying observations. The estimated magnitude for the dummy variable coefficient is an indicator of the unexpected change in PR possible during a period of great price uncertainty. It is important to note that although the dummy variable coefficient is estimated for two particular days, the estimated shift in the magnitude for the premium represented by the magnitude of the coefficient could apply to any day during a period of great uncertainty on natural gas spot and futures markets. It is also assumed, in this instance, that the distribution of the error terms is normal. The dummy variable represents all influences on PR on February 2nd and 3rd that are not accounted for by the other variables in the equation. However, industry perceptions probably account for a large part of these influences. The industry had passed through severely cold weather in midJanuary, experienced another dip in temperature at the end of January, and even though temperatures were rising in early February, yet another cold blast was forecasted. Pipeline capacity was tight and spot prices had been volatile during January's bid week in late January when most contracts for February deliveries are negotiated. Thus, the level of price uncertainty in the industry was probably great. When the equation is estimated with a dummy variable for the February observations, the following results are obtained (standard errors are reported in parenthesis):

$$
\begin{aligned}
& \mathrm{PR}_{\mathrm{t}}=0.265+0.017 \mathrm{DT} \mathrm{T}_{\mathrm{t}}-0.0080 \mathrm{TP}_{\mathrm{t}}+0.81 \mathrm{FEB} \\
& \begin{array}{c}
(0.051)(0.0026) \\
(0.0029) \quad(0.114)
\end{array} \\
& \mathrm{R}^{2}=0.761, \mathrm{n}=38 \text {, and the number of degrees of freedom }=34 .
\end{aligned}
$$

\section{Summary of Estimated Results for Equations 5 and 6}

The estimated magnitudes for the coefficients in equations 5 and 6 are similar in that the coefficients vary by less than a standard error. Therefore, the estimated results do not appear to be sensitive to the choice of estimator. Equation 6, however, is used to summarize the relationship between the price premium and the chosen variables. This choice is made because this estimation explains more of the variability in $\mathrm{PR}_{1}$ and because it also provides us with a useful estimate of the possible shift in the magnitude of the price premium during a period of much uncertainty.

\section{Evaluation of Estimated Results for Equation 6}

An examination of the plots of the residuals from equation 6 against the predicted value of PR and against DT and TP (Figures D1 through D3) did not reveal any pattern, such as an increase or decrease in the magnitude of the residuals as the magnitude of the explanatory variable or the predicted value of the premium increased. Thus, the assumption of the constancy of the variance of the error terms appears to be satisfied.

To evaluate the independence of the error terms, the standard Durbin-Watson test was examined which yielded a value of 1.99, strongly suggesting that the error terms one time period apart are independent. A runs test on the residuals was also examined. There were 20 negative residuals and 19 positive residuals. With this number of positive and negative residuals, the expected number of runs is 21 with a standard deviation of 3 runs. Since there are 18 runs in the residuals, the assumption of the independence of the error terms appears to be satisfied by this test as well.

In previous econometric investigations of PR (usually adjusted for the cost of borrowing money or the cost of storage implicit in the futures price) it was common to regress this variable on storage levels (S) to examine the degree to which the variable increases when $\mathrm{S}$ declines. However, this approach is not appropriate for natural gas markets because storage levels are judged to be low only when they are low relative to expected demand. For example, $1.8 \mathrm{Tcf}$ of gas can be considered very high for March, placing downward pressure on prices, but very low for January, putting upward pressure on prices because the amount of the demand that is expected to be satisfied from storage withdrawals is much higher for January than for March.

As a consequence of comments made by John Fenton of the Commodity Futures Commission (CFTC) (at a meeting of the Washington Statistical Society on Tuesday, November 22, 1994) that a variable representing daily storage levels should be useful for explaining $\mathrm{PR}$, an additional equation was estimated as a final step in evaluating equation 6 . This equation includes a variable 
Figure D1. Residuals Plotted Against Predicted Value for PR

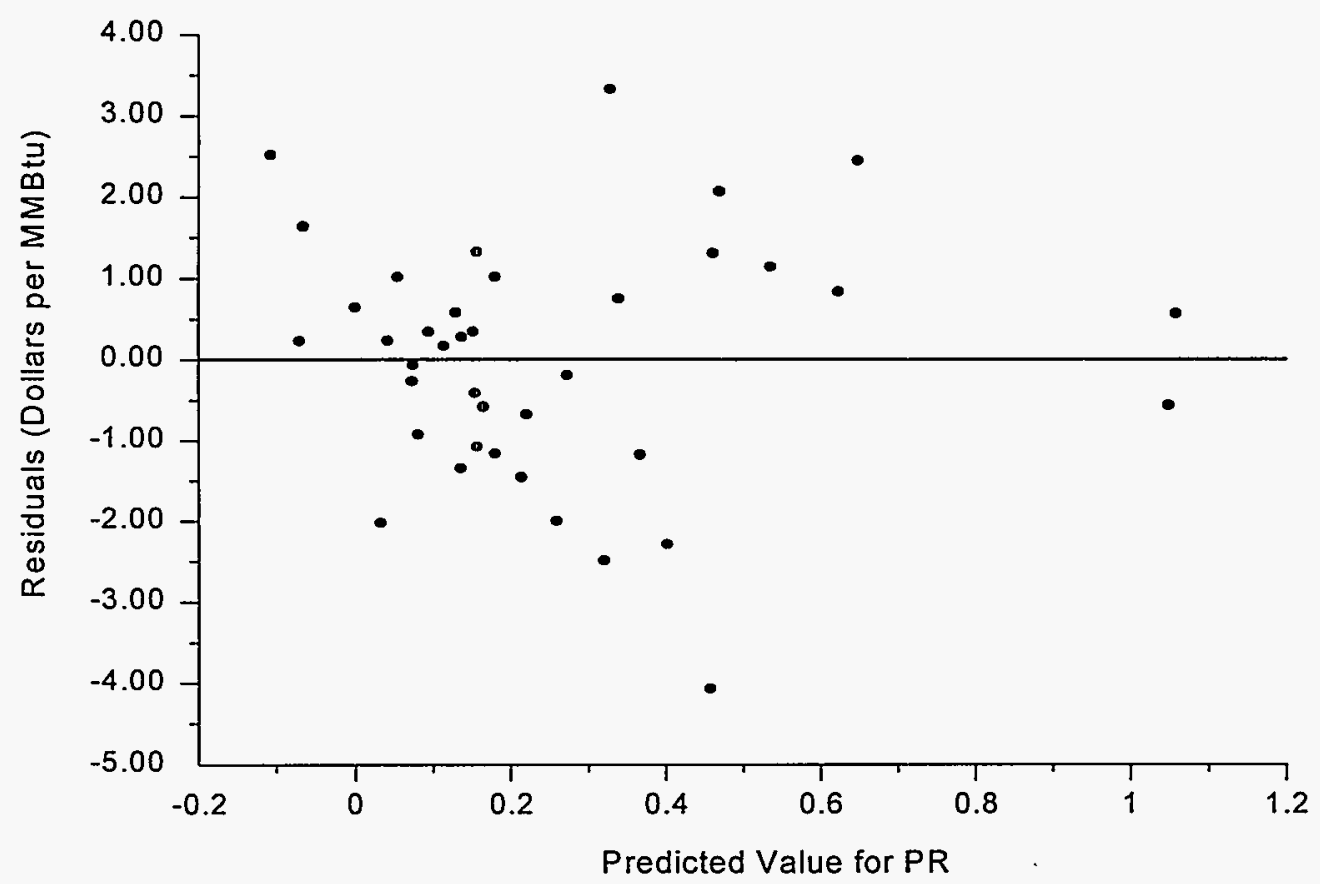

Source: Regression equation 6.

Figure D2. Residuals Plotted Against Variable DT

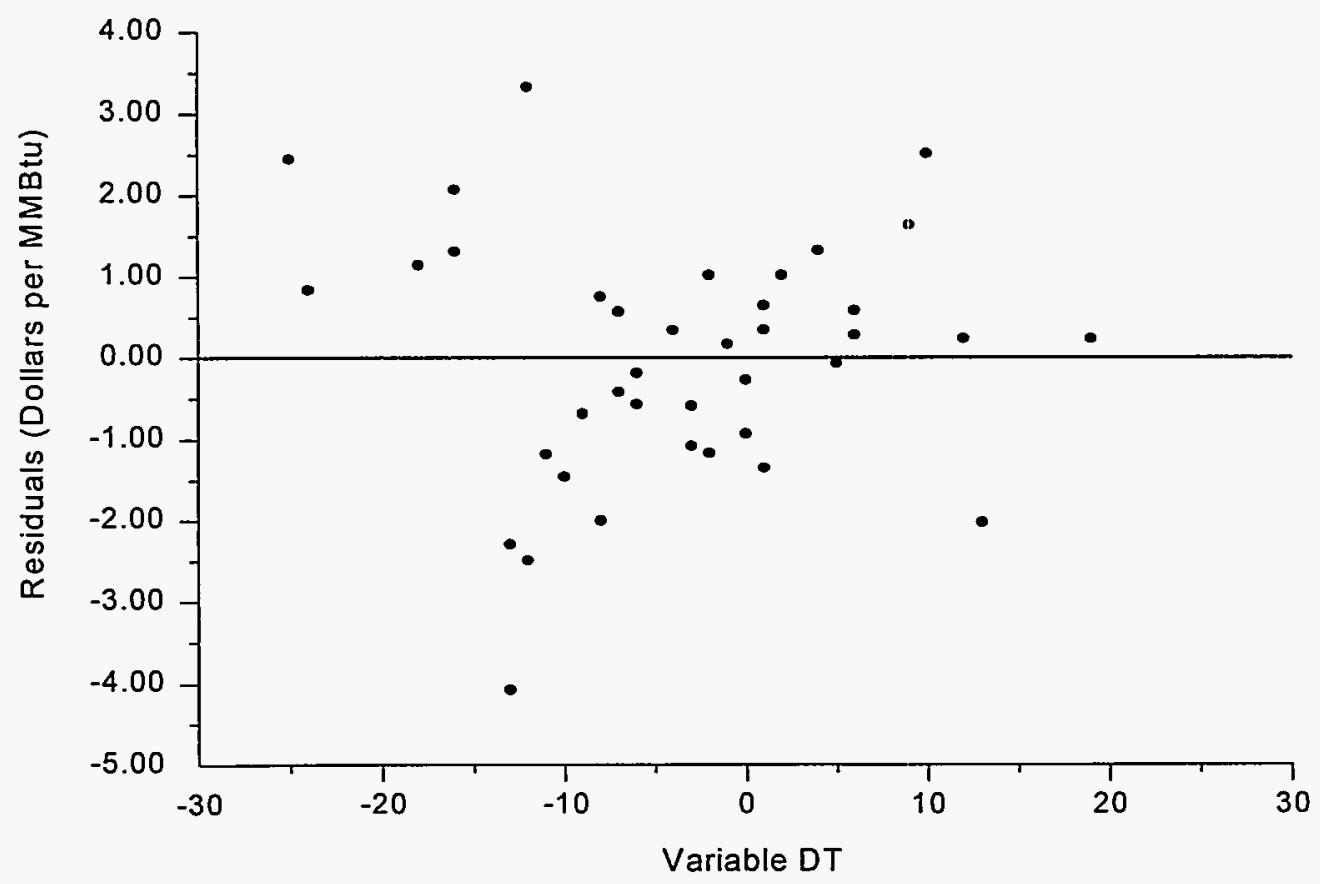

Source: Regression equation 6. 
Figure D3. Residuals Plotted Against Variable TP

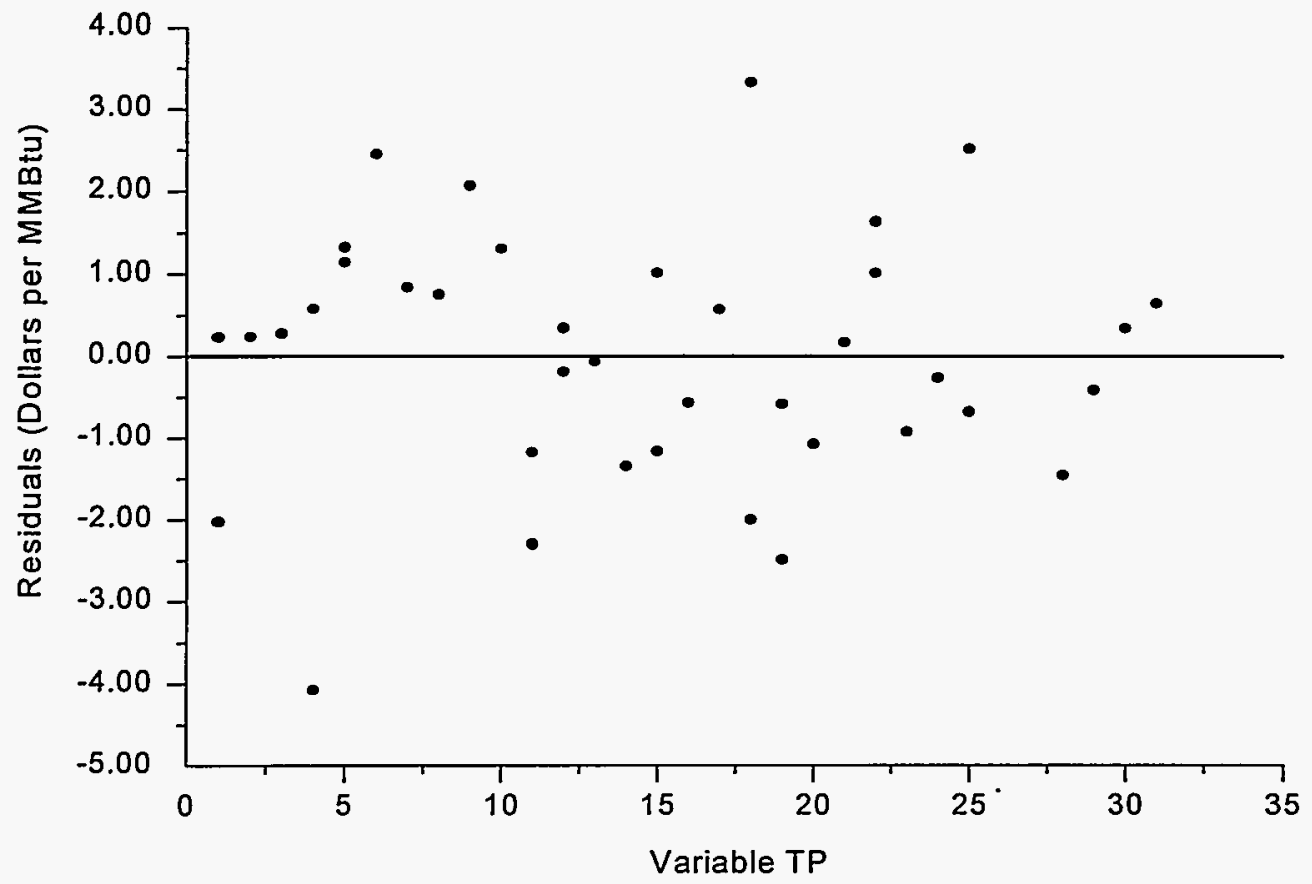

Source: Regression equation 6.

representing daily storage levels on day $t-1\left(S_{t-1}\right)$ relative to expected demand on the next day $\left(D_{t}\right)$. The procedure used to construct the variable is described below. In short, the American Gas Association's weekly storage statistics series is used to construct a daily gas storage series $\left(\mathrm{S}_{\mathrm{t}-\mathrm{l}}\right)$. This amount is, in turn, normalized by the inverse of daily normal temperatures on day $t$ (i.e., $1 / N_{1}$ ) which is used to represent expected deliveries on day $t$ because expected deliveries should be related to normal temperatures. For example, as daily normal temperatures decline, space-heating demands are expected to rise. Thus, the ratio $\left(\mathrm{S}_{\mathrm{t}-\mathrm{l}} /\left(1 / \mathrm{NT} \mathrm{T}_{\mathrm{t}}\right)\right.$ ) is a proxy variable for $\mathrm{S}_{\mathrm{t}-\mathrm{l}} / \mathrm{D}_{\mathrm{t}}$.

Daily values for $S$ are obtained by interpolating between weekly values of working gas in storage $S_{m}$, which is the amount of gas in storage reservoirs used to serve markets. The daily weights $\left(w_{v}\right)$ used for the interpolation are calculated in the following way:

$$
\mathrm{w}_{\mathrm{t}}=\left(\mathrm{HT}_{\mathrm{m}}-\mathrm{T}_{\mathrm{l}} / \Sigma_{\mathrm{l}}\left(\mathrm{HT}_{\mathrm{m}}-\mathrm{T}_{\mathrm{l}}\right)\right.
$$

where $\mathrm{HT}_{\mathrm{m}}$ is the high value for $\mathrm{T}$ (defined previously) experienced during week $\mathrm{m}$. The daily weights are multiplied by the change in working gas between week $\mathrm{m}$ and week $\mathrm{m}+1$ to obtain the daily decrements in working gas between weeks. These amounts are then subtracted from the working gas level at the end of week $\mathrm{m}$.

When the relationship between PR and DT, TP, FEB and the new variable $S_{t-1} / D_{t}$ is estimated, the following results are obtained (standard errors are reported in parenthesis):

$$
\begin{aligned}
& \mathrm{PR}_{\mathrm{t}}=0.385+0.017 \mathrm{DT} \mathrm{T}_{\mathrm{t}}-0.053\left(\mathrm{~S}_{\mathrm{t}} / \mathrm{D}_{\mathrm{t}+1}\right)-0.00785 \mathrm{TP}_{\mathrm{t}}+0.79 \mathrm{FEB} \\
& \begin{array}{l}
(0.108)(0.000025)(0.042) \\
\end{array} \\
& \mathrm{R}^{2}=0.764
\end{aligned}
$$

Thus, it is found that $S_{t-1} / D_{t}$ has the expected negative sign; that is, PR declines as storage levels rise relative to expected demands. However, the standard error of the coefficient relative to the magnitude of the coefficient indicates that the coefficient is not statistically different from zero. The $\mathrm{R}^{2}$ value increases only modestly between equations 6 and 8 . The estimated coefficients also do not change much between equations. 
The main reason for introducing $S_{t-1} / D_{t}$ into equation 6 is to reduce any bias in the other estimated coefficients from not including a variable that, in principle, belongs in the equation. This bias increases with the correlation between the $S_{t-1} / D_{t}$ and the other variables. Since the correlation between $S_{t-1} / D_{t}$ and the other variables is small, as indicated by lack of any change in the magnitude of the other coefficients when $S_{t-1} / D_{t}$ is included in the regression equation, it was decided that nothing is gained by including this variable in the regression equation.[19] It is probably best to conclude that $S_{t-1} / D_{v}$, as measured, is not a good proxy variable for daily storage levels (correctly measured) relative to expected demands, and little harm is introduced by not including it in the estimated equation. Little harm is done because changes in temperature between days tend to be independent and uncorreiated. DT is influenced by changes in temperature on day $t$. The level of $S_{t-1}$ is influenced by changes in temperature on day $\mathrm{t}-\mathrm{I}$. Thus, these two variables are probably uncorrelated.

In conclusion, the amount of variability in PR explained by equation 6 is probably less than it could be because a correctly measured stock variable is missing from the relationship. Yet, the estimated coefficients are not badly biased from not including this variable because there is probably not much correlation with the other variables included in the relationship.

\section{Spot Prices and a Storage Load Indicator}

(Pages 18 - 22)

\section{Specification and Estimation}

In the final estimation, it was decided to determine for the period January and February 1994 whether there was any relationship between the daily spot price at the Henry Hub (DSP) and cumulative deviations from normal temperatures, referred to as the "cold weather index" (CWI) in the text (the higher the value for the index the colder the weather for the time period over which the index was computed). CWI is also an indicator of cumulative withdrawals of gas above expected levels of withdrawals during the 2 months. CWI is probably best for comparing the severity of the winter for several years and comparing the price that evolved during these periods. For example, if the cold winter index is generally lower in year $t+1$ than in year $t$, one would expect price to be lower as well, other things being equal. As discussed in the text, comparing CWI values is similar to comparing heating degree day numbers for winter months. Generally, it is expected that there would be a positive relationship between DSP and CWI. When DSP is regressed on CWI using an OLS estimator (equation 9) and a LAD estimator (equation 10), the following estimated results are obtained (standard errors are given in parerthesis):

$$
\begin{gathered}
\mathrm{DSP}=2.08+0.0027 \mathrm{CWI} \\
(0.142)(0.00751) \\
\mathrm{R}^{2}=0.26 . \\
\mathrm{DSP}=2.08+0.0022 \mathrm{CWI} \\
(0.071)(0.00042) \\
\mathrm{R}^{2}=0.41 .
\end{gathered}
$$

\section{Evaluation}

As distinct from the other estimations reported in this appendix, these estimated equations are unreliable for several reasons. There is a significant first-order serial correlation between the residual values from both estimations. Thus, it is not possible to assume that the error terms are independent. Moreover, the magnitude of the residual tends to increase as CWI increases suggesting that the assumption of a constant variance of the error terms is also questionable. Nonetheless, the coefficients are stable, even though the standard errors of the coefficients are biased, and they provide a useful summary of the relationship between CWI and DSP for the time period. 


\section{References}

1. Pindyck, R. S. "Inventories and the Short-Run Dynamics of Commodity Prices." RAND Journal of Economics, Vol. 25, Spring 1994, pp. 141-159.

2. United States Department of Agriculture. Economic Research Service. Wheat - Situation and Outlook Report, May 1994.

3. Energy Information Administration. "Natural Gas Futures Contract Market - The First Two Years." Natural Gas Monthly, November 1992, DOE/EIA-0130(91/11). Washington, DC, November 1992, pp. 1-11.

4. Energy Information Administration. "Natural Gas Futures Market." Natural Gas 1992 Issues and Trends, DOE/EIA0560(92). Washington, DC, March 1993.

5. Herbert, J. H. "The Relation of Monthly Spot to Futures Prices for Natural Gas." Energy, Vol. 18, 1993, pp. 1,119-1,124.

6. De Vany A. and W. D. Walls. "Pipeline Access and Market Integration in the Natural Gas Industry: Evidence from Cointegration Tests." The Energy Journal, Vol. 14, 1993, 1-19.

7. De Vany, A. and W. D Walls. "Open Access and the Emergence of a Competitive Natural Gas Market." Contemporary Economic Policy, April, 1994, pp. 77-95.

8. Draper, N. and H. Smith. Applied Regression Analysis. New York: John Wiley \& Sons, Inc., 1981.

9. Chatterjee S. and A. S. Hadi. Sensitivity Analysis in Linear Regression. New York: John Wiley \& Sons, Inc., 1988.

10. Brennan, M. J. "The Supply of Storage." American Economic Review, Vol. 48, 1958, pp. 50-72.

11. Telser, L. G. "Futures Trading and the Storage of Cotton and Wheat." Journal of Political Economy, 66, June 1958, pp. 233-255.

12. Amundsen, Erik Schroder. "Seasonal Fluctuations of Demand and Optimal Inventories of a Non-renewable Resource Such as Natural Gas." Resources and Energy, Vol. 13, 1991, pp. 285-306.

13. Cho, D. W. and G. S. McDougall. "The Supply of Storage in Energy Futures Markets." The Journal of Futures Markets, Vol. 10, 1990, pp. 611-621.

14. Serletis, A. and Hulleman V. "Business Cycles and the Behavior of Energy Prices." The Energy Journal, Vol. 15, No. 2, 1994, 125-134.

15. Energy Information Administration. "Residential and Commercial Natural Gas Markets." Natural Gas Monthly, September 1985, DOE/EIA-0130(85/09). Washington, DC, September 1985, pp. XXI-XLIX.

16. Riddick, C. "A Regression Model for Explaining the Premium Value of Stored Gas in the United States." Virginia Polytechnic Institute and State University (Telestar Campus), Research Project for Statistics 5615, Statistics in Research, December 12, 1994.

17. Energy Information Administration. "Underground Storage of Natural Gas." Natural Gas Monthly, July 1987, DOE/EIA0130(87/07). Washington, DC, July 1987, pp. 9-22.

18. Birkes, David and Yadolah Dodge. Alternative Methods of Regression. New York: John Wiley \& Sons, Inc., 1993.

19. Herbert, J. H., and P. Kott. "An empirical note on regressions with and without a poorly measured variable." The Statistician, Vol. 37, 1988, pp. 293-298. 